Article

\title{
Trace Element Distributions in the Zn-Pb (Mississippi Valley-Type) and Cu-Ag (Kupferschiefer) Sediment-Hosted Deposits in Poland
}

\author{
Stanisław Z. Mikulski *(D), Sławomir Oszczepalski ${ }^{\circledR}$, Katarzyna Sadłowska, \\ Andrzej Chmielewski and Rafał Małek $D$ \\ Polish Geological Institute-National Research Institute, Rakowiecka 4, 00-975 Warszawa, Poland; \\ slawomir.oszczepalski@pgi.gov.pl (S.O.); katarzyna.sadlowska@pgi.gov.pl (K.S.); \\ andrzej.chmielewski@pgi.gov.pl (A.C.); rafal.malek@pgi.gov.pl (R.M.) \\ * Correspondence: stanislaw.mikulski@pgi.gov.pl; Tel.: +48-224592235
}

Received: 5 November 2019; Accepted: 11 January 2020; Published: 17 January 2020

check for updates

\begin{abstract}
We applied geochemical (ICP-MS, WD-XRF, GFAAS, and AMA 254) and mineralogical (EPMA) studies of 137 samples to ore mineralization from Middle-Triassic sediment-hosted $\mathrm{Zn}-\mathrm{Pb}$ (Mississippi Valley-type MVT) and Lower Zechstein sediment-hosted stratiform (SSC) Cu-Ag (Kupferschiefer-type) deposits in Poland. They contain a number of trace elements which are not recovered during the ore processing. Only $\mathrm{Cu}, \mathrm{Ag}, \mathrm{Pb}, \mathrm{Ni}, \mathrm{Re}, \mathrm{Se}, \mathrm{Au}$, and PGE are extracted from $\mathrm{Cu}-\mathrm{Ag}$ deposits while $\mathrm{Zn}$ and $\mathrm{Pb}$ are the only elements produced from $\mathrm{Zn}-\mathrm{Pb}$ deposits. $\mathrm{Zn}$ - $\mathrm{Pb}$ deposits contain $\mathrm{Cd}, \mathrm{Ag}, \mathrm{Ga}$, and $\mathrm{Ba}$ in slightly elevated concentrations and have potential to be mineral resources. This applies to a lesser extent to other trace elements (Bi, As, Hf, Tl, Sb, Se, and Re). However, only $\mathrm{Cd}$ and $\mathrm{Ag}$ show high enrichment factors indicative of potential for recovery. The bulk-rock analyses reveal strong correlations between $\mathrm{Zn}$ and $\mathrm{Cd}$ and $\mathrm{Se}$, As and Mo, and weaker correlations between $\mathrm{Ag}$ and $\mathrm{Cd}$, as well as $\mathrm{Ga}$ and $\mathrm{Zn}$. Electron microprobe analyses of sphalerite revealed high concentrations of $\mathrm{Cd}(\leq 2.6 \mathrm{wt} \%)$ and $\mathrm{Ag}(\leq 3300 \mathrm{ppm})$. $\mathrm{Zn}-\mathrm{Pb}$ deposits have fairly significant estimated resources of $\mathrm{Ga}$ and $\mathrm{Sc}(>1000$ tons) and $\mathrm{Cd}(>10,000$ tons). The $\mathrm{Cu}$ - $\mathrm{Ag}$ deposits have element signatures characterized by high values of $\mathrm{Co}, \mathrm{V}, \mathrm{Ni}$, and $\mathrm{Mo}$ and much lower of $\mathrm{Bi}$, As, $\mathrm{Cd}, \mathrm{Hg}, \mathrm{Mo}, \mathrm{Sb}$, and Tl. Bulk-rock analyses show strong correlations between Se and V; As and Co; $\mathrm{Bi}$ and $\mathrm{Re}$; and weaker correlations between, for example, $\mathrm{Cu}$ and $\mathrm{Mo} ; \mathrm{V}, \mathrm{Ni}, \mathrm{Ag}$ and $\mathrm{Mo}$; and $\mathrm{Ni}, \mathrm{V}$, and $\mathrm{Co}$ and $\mathrm{Ni}$. The EPMA determinations reveal strong enrichments of $\mathrm{Ag}$ in $\mathrm{Cu}$ sulfides (geerite $\leq$ $10.1 \mathrm{wt} \%$, chalcocite $\leq 6.28 \mathrm{wt} \%$, bornite $\leq 3.29 \mathrm{wt} \%$, djurleite $\leq 9080 \mathrm{ppm}$, yarrowite $\leq 6614 \mathrm{ppm}$, and digenite $\leq 3545 \mathrm{ppm}$ ). Silver minerals and alloys, as well as the native $\mathrm{Ag}$ and $\mathrm{Au}$, were recorded in the Cu-Ag ores. Large resources of $\mathrm{Co}, \mathrm{V}$, and $\mathrm{Ni}$ (>100,000 tons) and $\mathrm{Sc}$ and $\mathrm{Mo}$ (>10,000 tons) are notable in $\mathrm{Cu}-\mathrm{Ag}$ deposits. A number of trace elements, classified as critical for the economy of the European Union, including $\mathrm{Ga}$ and $\mathrm{Ba}$ (to a lesser extent $\mathrm{Hf}, \mathrm{Nb}$, and $\mathrm{Sc}$ ) in $\mathrm{Zn}-\mathrm{Pb}$ deposits, and $\mathrm{Co}$ and $\mathrm{V}$ in the $\mathrm{Cu}-\mathrm{Ag}$ deposits, may eventually be recovered in the future from the studied deposits if proper ore-processing circuits and increasing demand are favorable.
\end{abstract}

Keywords: trace elements; critical elements; geochemistry; ore mineralogy; Zn-Pb MVT deposits; $\mathrm{Cu}-\mathrm{Ag}$ Kupferschiefer SSC deposits; Poland

\section{Introduction}

Poland has the following two world-class mining districts that produce base metals: (1) the Silesia-Cracow district with the Mississippi Valley-type (MVT) Zn-Pb deposits hosted by the Middle-Triassic carbonate formations, and (2) the Lubin-Sieroszowice copper district with the 
sediment-hosted stratiform (SSC) Cu-Ag (Kupferschiefer-type) deposits hosted by the Zechstein copper-bearing series. The $\mathrm{Zn}-\mathrm{Pb}$ deposits are mined to produce $\mathrm{Zn}$ and $\mathrm{Pb}$ while $\mathrm{Cu}$ and $\mathrm{Ag}$ determine the economic value of the Kupferschiefer deposits. In addition, $\mathrm{Au}, \mathrm{PGE}, \mathrm{Pb}, \mathrm{Ni}$, Se, and $\mathrm{Re}$ are also recovered in the processing of $\mathrm{Cu}-\mathrm{Ag}$ ores produced by KGHM Polska Miedź S.A. mines [1]. However, while certain elements are recovered, questions remain as to whether other elements could occur at sufficient concentrations to be of economic interest now or in the future.

In these two main metal districts, 32 ore deposits with identified resources are documented [1]. The Silesia-Cracow region has a long tradition of $\mathrm{Zn}$ and $\mathrm{Pb}$ mining, dating back to the Middle Ages [2-4] and was regarded as the world's largest area of the MVT-type Zn-Pb deposits [5]. The total ore resources amounted to approximately 0.7 billion tons with an average content of $\mathrm{Zn}+\mathrm{Pb}$ from $4 \%$ to $6 \%$ during the last two decades [6]. Currently, the identified resources amount to c.a. $84 \mathrm{Mt}$ of ore yielding 3.6 Mt of $\mathrm{Zn}$ and $1.4 \mathrm{Mt}$ of $\mathrm{Pb}$. The deposits are mined at depths of between 40 and $240 \mathrm{~m}$. The ores are mined with a production of $43 \mathrm{kt}$ of $\mathrm{Zn}$ and $13 \mathrm{kt} \mathrm{Pb}$ in 2018 [1]. The Lubin-Sieroszowice Copper District, discovered in 1957 by Polish Geological Institute, ranks as one of the largest in the world. Identified resources in the Lubin-Sieroszowice (L-S) deposit amount to a total of $1802.5 \mathrm{Mt}$ of ore containing $32.6 \mathrm{Mt}$ of $\mathrm{Cu}$ and $97.94 \mathrm{kt}$ of Ag including $1663.0 \mathrm{Mt}$ of ore (30.4 Mt of $\mathrm{Cu}$ and $86.8 \mathrm{kt}$ of Ag) in developed deposits and 139,535 Mt of ore (2.2 Mt of $\mathrm{Cu}$ and $11.1 \mathrm{kt}$ of Ag) in undeveloped deposits [1]. Deposits are mined at depths of between about 600 and $1300 \mathrm{~m}$. In 2018, KGHM, the sole producer of $\mathrm{Cu}$ in Poland, mined 30,253 Mt of ore at $1.49 \% \mathrm{Cu}$ and $48.6 \mathrm{ppm} \mathrm{Ag}$, comprising 451 thousand tons of $\mathrm{Cu}$ and 1471 tons of $\mathrm{Ag}$. Maximum average grades are typical of the shale ore $(5.4 \% \mathrm{Cu}$ and $134 \mathrm{ppm}$ $\mathrm{Ag}$ ). In the same year KGHM recovered $501.8 \mathrm{kt}$ of electrolytic $\mathrm{Cu}$ along with 1189 tons of $\mathrm{Ag}$, $523 \mathrm{~kg}$ of $\mathrm{Au}, 27.21 \mathrm{kt}$ of $\mathrm{Pb}, 66.36$ tons of Se, $1.73 \mathrm{kt}$ of nickel sulfate, as well as sulfuric acid and $\mathrm{Cu}$ sulfate. In addition, $2587 \mathrm{~kg}$ of $\mathrm{Au}, \mathrm{Pt}$, and $\mathrm{Pd}$ and 9.09 tons of Re were produced, both from their own and foreign concentrates.

In this article, we present whole rock geochemical results of studies of mineralized samples from these two major districts in order to determine the concentrations of over 40 trace elements from which some have potential interest in these deposits. Moreover, key elements have been recently considered critical to the world economy (e.g., [7-15]). Results of electron microprobe analyses of selected minerals are also presented in order to determine the residence of these elements.

\section{Geological Setting of $\mathrm{Zn}-\mathrm{Pb}$ and $\mathrm{Cu}-\mathrm{Ag}$ Sediment-Hosted Deposits in Poland}

\subsection{Zn-Pb Mississippi Valley-Type Deposits}

The Silesia-Cracow $\mathrm{Zn}-\mathrm{Pb}$ district is located north of the Carpathian nappes, overlapping in the southwest the margins of the Upper Silesia Coal Basin and in the northeast the transition zone between the Upper Silesia Block (Brunovistullian Terrane) and Małopolska Block (Małopolska Terrane) (Figure 1A,B). These blocks concealed under the Mesozoic-Cenozoic platform cover are separated by the Cracow-Lubliniec Fault Zone (KLFZ, Figure 1A), [16] being a part of the transcontinental Hamburg, i.e., the Cracow tectonic zone that constitutes the Trans-European tectonic suture zone (TESZ) separating the East-European Craton (Laurussia-Baltica) from mosaic terranes in Western and Central Europe (Gondwana blocks, e.g., [17] and references therein). 


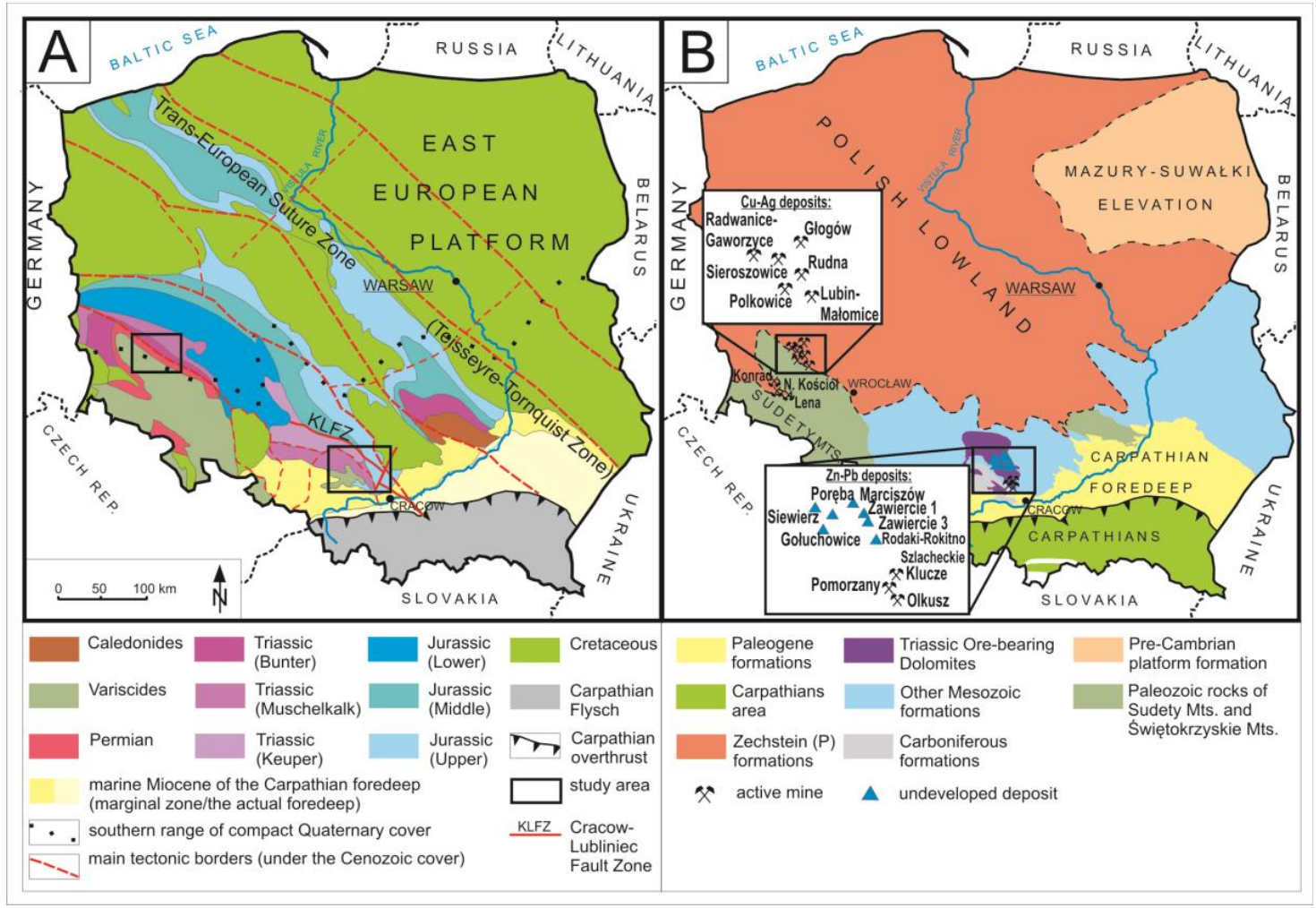

Figure 1. (A) A simplified geological map of Poland without Cenozoic cover (after [6]), with main tectonic borders under the Cenozoic cover and (B) the main metallogenic formations of Poland (after [18]) with location of investigated $\mathrm{Zn}-\mathrm{Pb}$ and $\mathrm{Cu}-\mathrm{Ag}$ deposits.

The Triassic displays characteristic tripartition reflecting the principal transgression-regression cycle, that commenced with Buntsandstein continental clastics that were followed by marine carbonates of the Muschelkalk (Middle Triassic) and terminated along an erosional paleo-morphology with continental Keuper evaporates, claystones, and clastics [19]. The Muschelkalk carbonate sediments are subdivided into several members (Figure 2) consisting of limestones and early diagenetic dolomite ([3] and references therein). The Triassic sediments cover discordantly the Variscan basement comprising the Devonian and Carboniferous rocks. The Mesozoic cover generally dips toward the northeast, which reflect the vertical crustal mobility of this region, influencing periodic connection between the southern part of the northwestern European basin and the Tethys Ocean during the Mesozoic [19]. The $\mathrm{Zn}-\mathrm{Pb}$ deposits are related to carbonate and siliciclastic rock formations with Permian-Mesozoic successions resting monoclinally on the pre-Permian basement [16-19]. The $\mathrm{Zn}-\mathrm{Pb}$ mineralization is hosted by rocks ranging in age from the Devonian to Jurassic (Figure 2). However, resources of economic value are mainly confined to the so-called "ore-bearing dolomites" of the Muschelkalk [2,3,20-22]. 


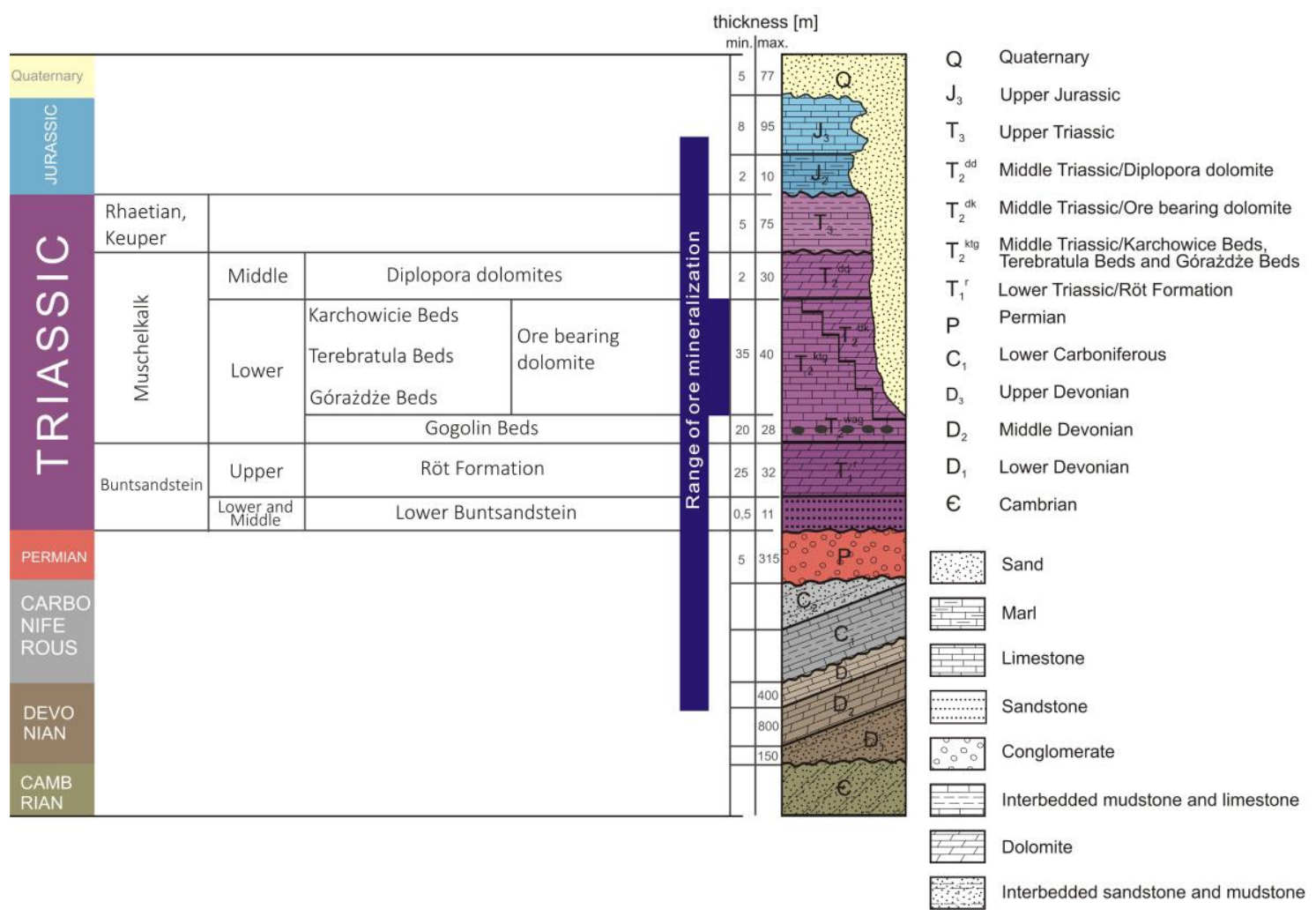

Figure 2. Schematic lithostratigraphic position of the $\mathrm{Zn}-\mathrm{Pb}$ ore series within sedimentary rocks in the Silesia-Cracow district modified after [6].

The deposits are spread over an area of approximately $1000 \mathrm{~km}^{2}$ and they are grouped into the following four regions: Chrzanów, Olkusz, Bytom, and Zawiercie (Figure 3A). The Klucze I, Olkusz and Pomorzany deposits in the Olkusz area are currently mined. The deposits of the Bytom and Chrzanów regions have been exhausted and now comprise some subeconomic resources, which are mainly $\mathrm{Zn}$-oxide ores. In the Zawiercie region, mining has not yet started but exploration is still on-going [23-25]. The $\mathrm{Zn}-\mathrm{Pb}$ deposits range in size generally from a few to a dozen $\mathrm{km}^{2}$ and are located at a depth from 40 to $240 \mathrm{~m}$ below surface level [3]. The ores occur in the form of pseudo layers, sub-horizontal lenses, and nest-like replacements (Figure 3B).

Approximately $95 \%$ of all metal production comes from the ore-bearing dolomites, and the rest from the dolomites of Rhaetian and Devonian [6]. The ore-bearing dolomites are represented by an epigenetic dolosparite, which often is discordant to the Middle Triassic limestones and early diagenetic dolomites $[2,3,21,23]$. According to Szuwarzyński ([2] and references therein) two types of ore-bearing dolomites are distinguished; the early variety is represented by dolostone and calcareous dolostone with relatively low abundances of Fe and base metals that forms large tabular bodies within the Muschelkalk beds, and the second (younger) variety of ferruginous dolomite, occurring as hosts and haloes around the ore mineralization, enriched in $\mathrm{Zn}, \mathrm{Pb}$, and Fe. Alpine block-fault tectonics determine the extent, location, and distribution of ore bodies in particular regions [6,21]. The fault orientation generally follows old tectonic lines of the basement, which were repeatedly reactivated. The dominant are network faults with NW-SE, N-S, and NNE-SSW striking directions and vertical slips are around 50 to $70 \mathrm{~m}[3,20,21]$. During the Early Cimmerian tectonic phase in the Early Jurassic, the area was uplifted and the karstifications processes took place. Major tectonic deformations, faulting, and north-northeast dipping of the Silesia-Cracow monocline was related to the Early to Late Tertiary phases of the Alpine orogeny that formed the Carpathian fold belt and foredeep [3,20,21]. 


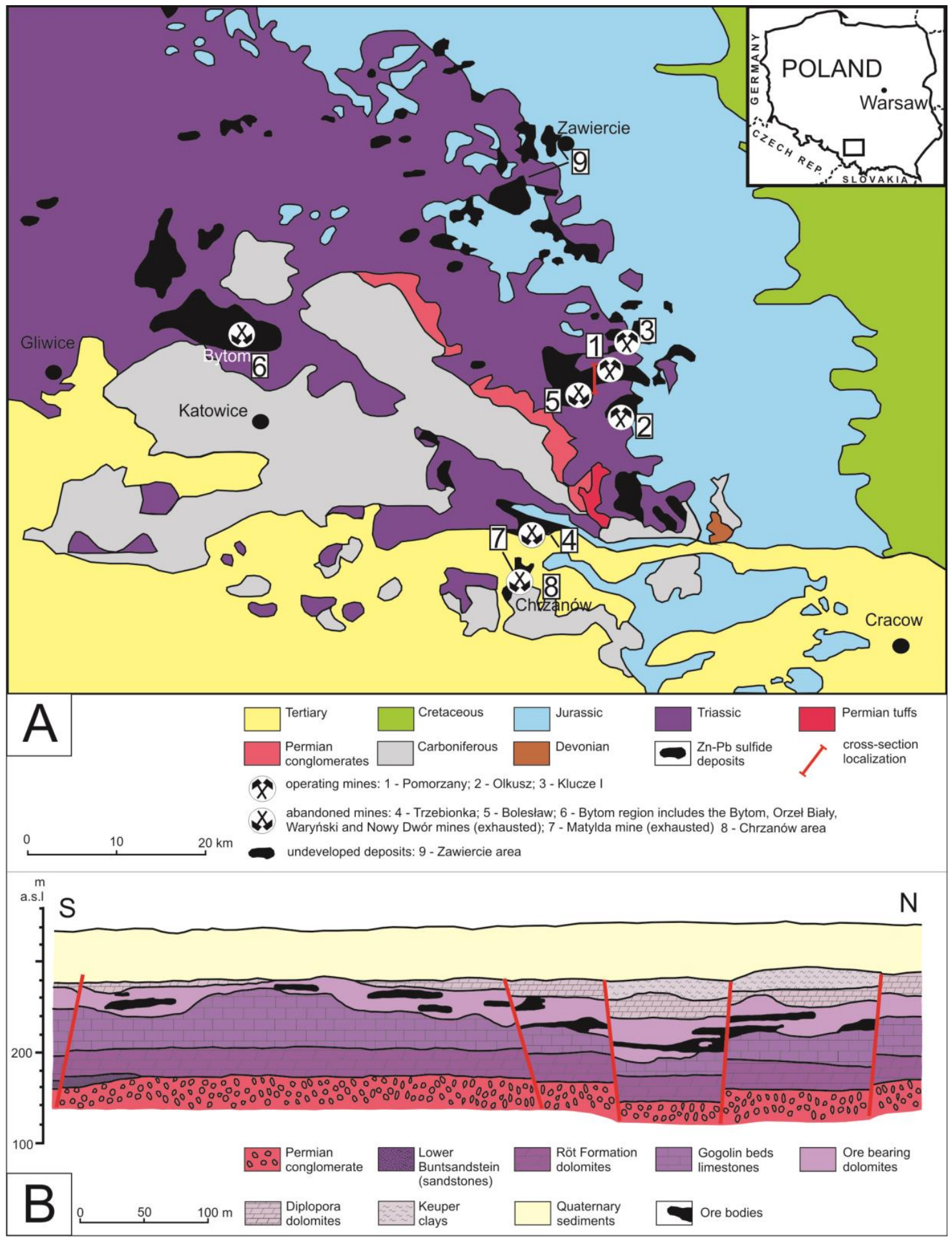

Figure 3. (A) Location of the $\mathrm{Zn}-\mathrm{Pb}$ active and abandoned mines and undeveloped deposits on the schematic geological background (without Quaternary sediments) in the Silesia-Cracow Zn-Pb district, modified after [3] and (B) cross-section through the $\mathrm{Zn}-\mathrm{Pb}$ ore deposit of the Pomorzany mine modified after [22].

Ore Mineralization

The $\mathrm{Zn}$ and $\mathrm{Pb}$ grades in sulfide ores range usually from $2 \%$ to $4 \% \mathrm{Zn}$ and from $1 \%$ to $2 \% \mathrm{~Pb}$ [6]. $\mathrm{The} \mathrm{Zn} / \mathrm{Pb}$ ratio in the operated deposits is about 3:1. Sulfide mineralization occurs in the form of laminae, impregnation, veinlets, collomorphic and banded (Figure 4A-E) or ribbon incrustations, breccia cement 
(Figure 4E), and sporadically infiltration textures [26-28]. The Zn-Pb sulfide ores comprise variable generation of sphalerite, galena, pyrite, melnikovite, and marcasite [27-31]. In addition, rare occurrences of sulfoarsenides (jordanite $\mathrm{Pb}_{14}(\mathrm{As}, \mathrm{Sb})_{6} \mathrm{~S}_{23}$ and gratonite $\left.\mathrm{Pb}_{9} \mathrm{As}_{4} \mathrm{~S}_{15}\right)$ and chalcopyrite have been reported [29]. The following gangue minerals are distinguished that are associated by organic carbon: dolomite, barite, calcite, chalcedony, and quartz [3,21,22,29,32]. Generalized paragenetic sequence for minerals from the Silesia-Cracow $\mathrm{Zn}-\mathrm{Pb}$ district after [28] is shown in Figure 5. The second and third stages are of economic importance, due to abundant sphalerite and galena crystallization of the successive generations. The first ore stage began with the earliest galena (Gn1) precipitation, postdated by first significant light tan banded sphalerite (SpLB), followed by dark brown banded sphalerite (SpDB1) with characteristic colloform texture (SLB), and by galena (Gn2) $[26,28,30,33]$. The second ore stage (stage 3 ) is characterized by abundant pyrite and marcasite (McPy2 and McPy3) in paragenetic association with a second band of dark brown, banded sphalerite (SpDB2) and with galena (Gn3). The pre-ore stage represents pyrite, marcasite (McPy1), and granular sphalerite (Spg), whereas the post-ore stage is dominated by barite, calcite, Fe-sulfides, minor granular sphalerite, and brunckite $[28,29,34,35]$. Despite the widespread occurrence of paragenetic $\mathrm{Zn}-\mathrm{Pb}-\mathrm{Fe}$ sulfides, it should be noted that they are very diverse in the frequency of mutual occurrence of a particular stage from site to site $[3,6,23,28,29]$. Sphalerite-galena ores contain Fe sulfides in the range from $6 \%$ to $15 \%$ in the Olkusz mine and $<2 \%$ in the Trzebionka deposit $[2,6]$.
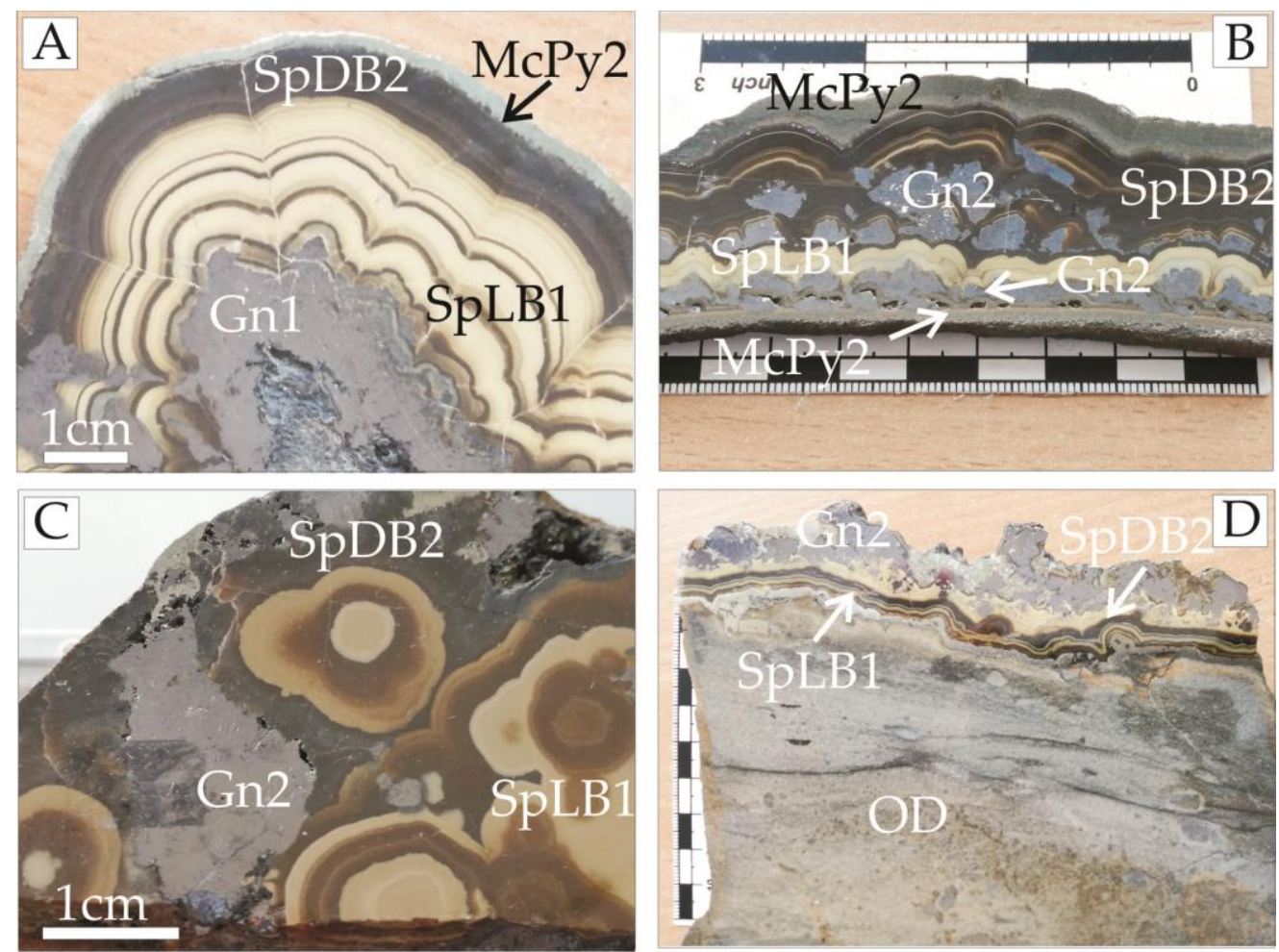

Figure 4. Cont. 

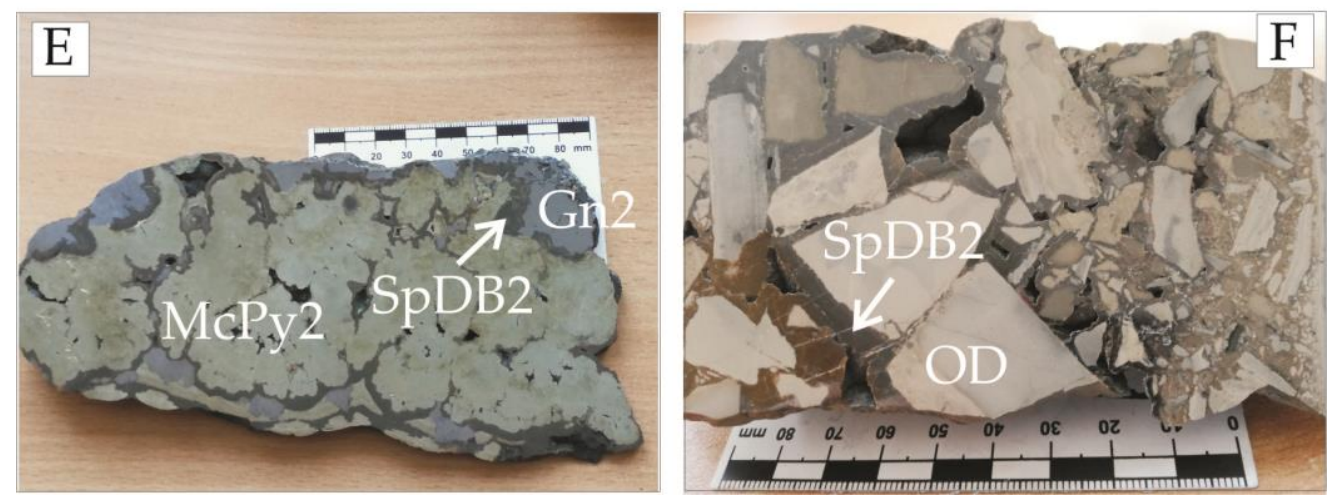

Figure 4. Typical massive sphalerite-galena-marcasite ore from the Mississippi Valley-type (MVT) deposits in the Silesia-Cracow district. (A-E) Characteristic colloform Zn-Pb-Fe ore composed of cryptocrystalline (rhythmic or botryoidal) sphalerite (SpLB1, SpDB2 for explanation see Figure 5), rod-like fibrous marcasite (McPy2), and coarse crystalline or metacolloidal galena (Gn1, Gn2). The Olkusz (A,C) and Trzebionka (B) mines; (D) ore-bearing dolomite (OD) with colloform Zn-Pb-Fe ore represented by sphalerite (SpLB1, SpDB2)-marcasite and coarse crystalline galena (Gn2); Pomorzany mine (E) massive crystalline marcasite pyrite (McPy2) with sphalerite (SpDB2) and galena (Gn2) coatings; and the Pomorzany mine (F) brecciated ore-bearing dolomite (OD) cemented by dark brown sphalerite (SpDB2), the Trzebionka mine.

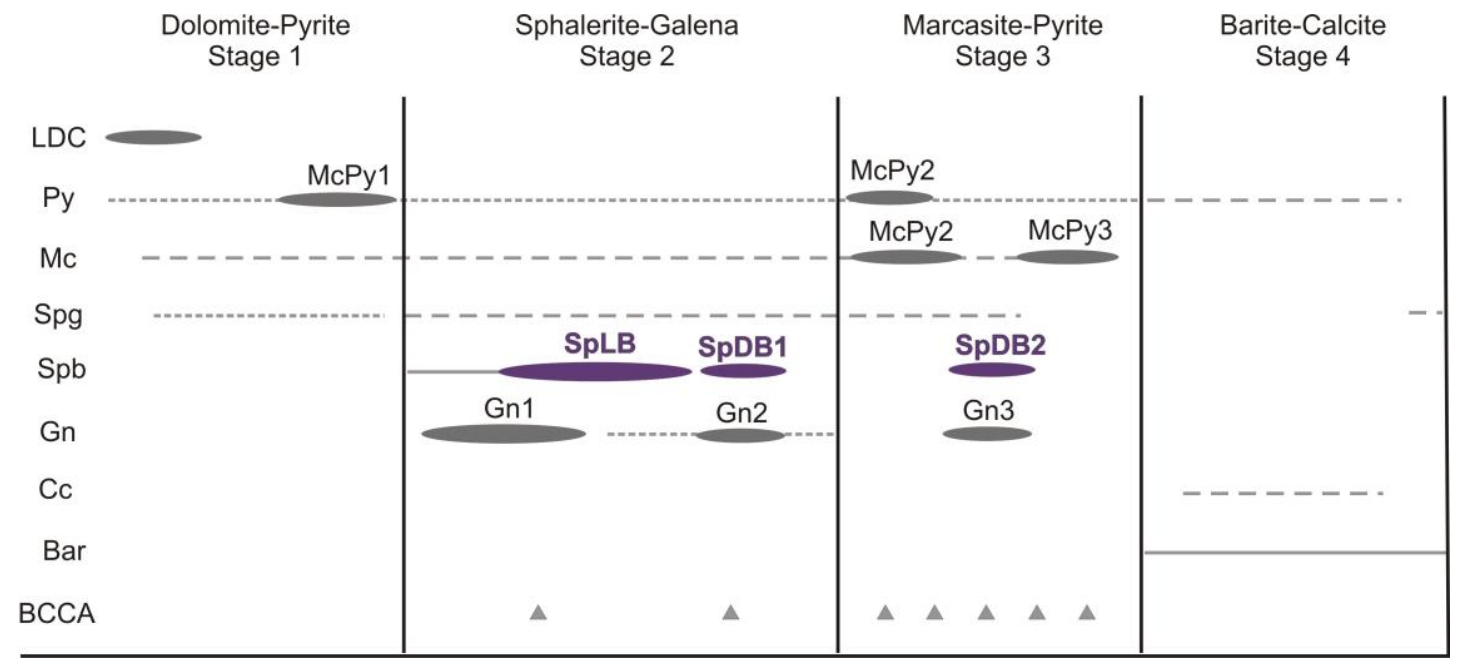

Figure 5. Generalized paragenesis of mineralization in the $\mathrm{Zn}-\mathrm{Pb}$ Silesia-Cracow district (after [28]). LDC, late dolomite cement; McPy1, 2, 3, the successive stages of marcasite (Mc) and pyrite (Py); Gn1, 2, 3 , the successive stages of galena; $\mathrm{Spg}$, granular sphalerite; $\mathrm{Spb}$, banded sphalerite; SpLB, light coloured, banded or colloform sphalerite from stage 2; SPDB1, first dark banded sphalerite in stage 2; SpDB2, second dark banded sphalerite in stage 3; Cc, calcite; Bar, barite; and BCCA, breccia.

The $\mathrm{Zn}-\mathrm{Pb}$ ore contain sphalerite with the largest share of $\mathrm{Ag}$, Fe and $\mathrm{Cd}, \mathrm{Tl}$ and As, remarkably high in some galena, and sphalerite, reaching thousands of ppm or even weight percent level $[28,29,36]$.

In addition to sulfide ores, which occur in the entire district, the nonsulfide Zn ores (called "galmans") occur and were subject to production. Two types of galmans were recognized [37]. The first one, a highly ferruginous red galman containing hydrous iron oxides (mainly goethite), smithsonite, and hemimorphite; and the second one, white galman (not very common) enriched in Fe-smithsonite and Zn-dolomite. Traces of Mn, Co, and Ni have been detected in smithsonite ([37], and references therein). Red galmans are considered as a product of $\mathrm{Zn}$-sulfide ore supergene processes and white galmans as a result of low temperature hydrothermal alteration related to the same fluids that precipitated the $\mathrm{Zn}-\mathrm{Pb}$ ores [37]. 
An epigenetic low temperature hydrothermal MVT-style origin of the Zn-Pb Silesia-Cracow deposits has been proposed [5,21,28,31,34,35]. However, the timing of ore emplacement is still debatable and considered as the following: (1) Late Triassic to Middle Jurassic [38], (2) Early Cretaceous [31], or (3) Early Tertiary $[21,28,39]$.

\subsection{Cu-Ag Sediment-Hosted Stratiform Deposit on the Fore-Sudetic Monocline}

The Lubin-Sieroszowice (L-S) Copper District is located in the central part of the Fore-Sudetic Monocline that borders with the Fore-Sudetic Block. This district comprises six mining areas (Deep Głogów, Lubin-Małomice, Polkowice, Radwanice-Gaworzyce, Rudna, and Sieroszowice, (Figures 1B and 6) shared by three underground mines, i.e., Lubin, Polkowice-Sieroszowice, and Rudna. The L-S deposit represents the sediment-hosted stratiform type that occurs in the contact zone between the Zechstein and Rotliegend groups. The Polish Zechstein Basin forms a southeastern extension of the Southern European Permian Basin [40]. Deposition in the Polish Zechstein Basin commenced with flooding of the continental Rotliegend Basin as a result of rifting-induced subsidence combined with a contemporaneous rise in sea level. The Zechstein Basin, about $1700 \mathrm{~km}$ long, extended from eastern England to western Lithuania, Estonia, and Belarus. As a result of transgression and cyclically progressing changes in the Zechstein Basin palaeogeography, the following four basic cycles were deposited: Z1 (Werra), Z2 (Stassfurt), Z3 (Leine), and Z4 (Aller). Cu-Ag ore mineralization is restricted to the Zechstein copper-bearing series, i.e., the Weissliegend sandstones (Ws), the Basal Limestone (Ca0), the Kupferschiefer (T1), and the Zechstein Limestone (Ca1). Locally, mineralization occurs at the lowermost part of the Lower Anhydrite (A1d) (Figure 7). The Weissliegend sandstone includes light gray sandstones, in the lower part of which there are aeolian sandstones and in the upper part-transgressive sandstones with numerous small sedimentary structures and bioturbations (locally with marine fauna), created due to redeposition of terrestrial sandstones. Its thickness can locally reach $40 \mathrm{~m}$. On some paleoelevations there are no sandstones and transgressive conglomerates. In the initial period of a stabilizing sea conditions, the nearshore Basal Limestone was formed (known as the Border Dolomite in the L-S Copper District). Its thickness is usually insignificant; it reaches several dozen centimeters. The Kupferschiefer represents the mature stage of transgression associated with the increase in the sea level. Its sedimentation took place under the reducing conditions of the stratified epicontinental sea [41]. The age of the Kupferschiefer is determined as $258 \mathrm{Ma}$ [42] and the age of the ore mineralization is considered as a result of multiply processes that underwent according to variable geochronological methods as Late Permian-Early Triassic [43,44], Late Triassic [45,46], or Triassic-Early Jurassic age [47]. The origin was also referred to as being of a multistage and long-term origin [48-51]. The ore mineralizing processes were connected with a late diagenesis and further migration of low temperature oxidized hydrothermal fluids, which were reduced on a large scale along a redox front of the reducing basal Zechstein sediments [52-55]. The Kupferschiefer has variable thickness, usually between 30 and $60 \mathrm{~cm}$. It generally overlies either the Weissliegend sandstones and rarely the Rotliegend volcanics or pre-Permian rocks. It is absent from marginal parts of the Zechstein basin and from the elevated parts of ridges. It comprises laminated clay- and mudstones composed of clay minerals (mainly illite with minor montmorillonite and kaolinite), carbonates (dolomite commonly prevails over calcite), and organic matter. These sediments were formed at the sea bottom located below the wave base under anaerobic conditions. The Kupferschiefer is overlain by the Zechstein Limestone deposited under oxygenated conditions. Its sequences are characterized by a regressive nature expressed by the presence of mudstones in the lower part, as well as wackestones, packstones, and boundstones in the upper part of profiles. The Zechstein Limestone is followed by the Lower Anhydrite (A1d), Oldest Halite (Na1), and Upper anhydrite (A1g). These rocks constitute the evaporative phase of the Zechstein Sea during the deposition of the first Zechstein cycle. 


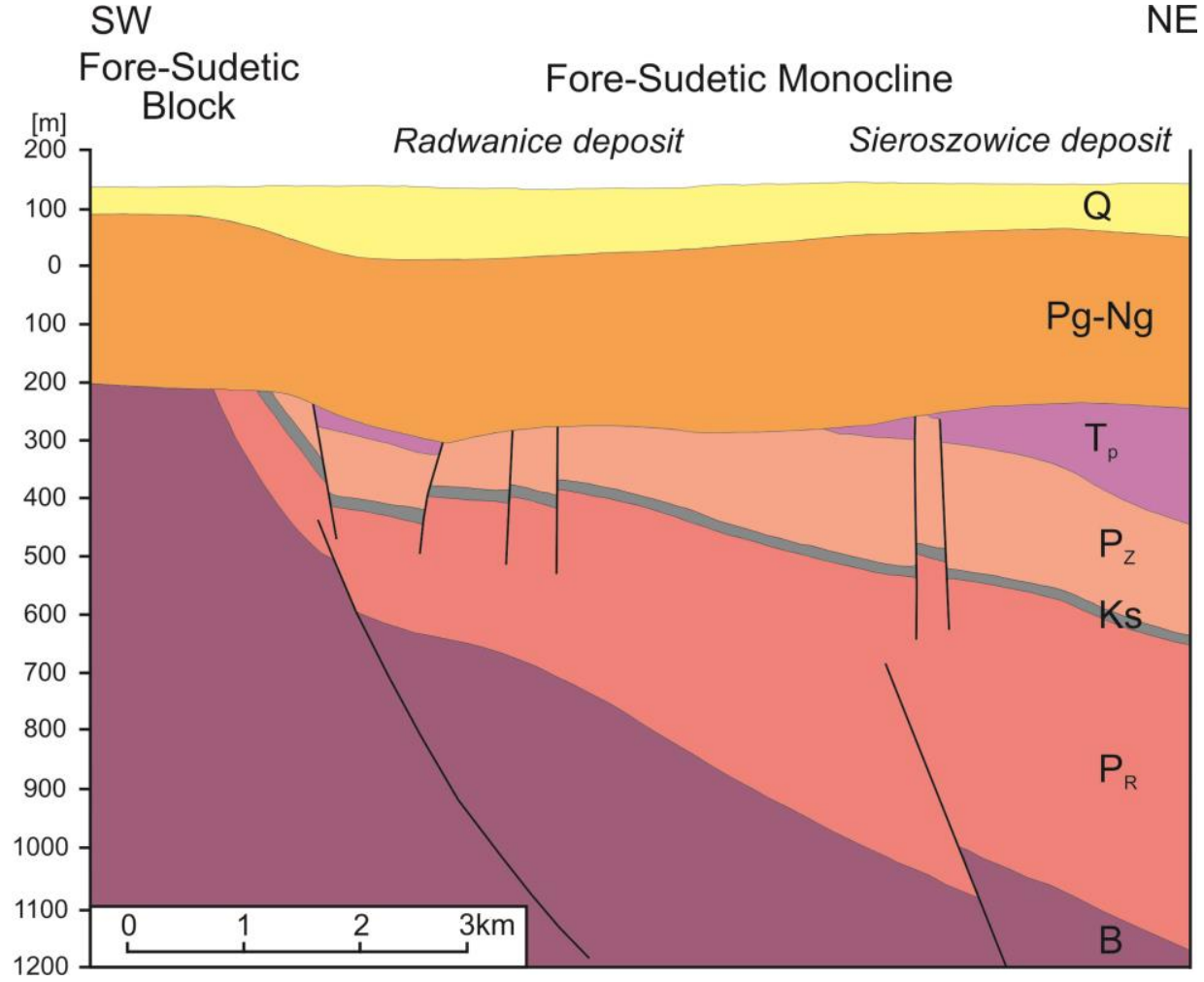

Figure 6. Schematic cross-section across the contact zone between the Fore-Sudetic Block and the Fore-Sudetic Monocline through the Radwanice deposit and SW part of the Sieroszowice deposit. Q, Quaternary; Pg-Ng, Paleogene-Neogene; Tp, Buntsandstein; Pz, Zechstein; Ks, Kupferschiefer series; $\mathrm{P}_{\mathrm{R}}$, Rotliegend; and $\mathrm{B}$, pre-Permian basement.

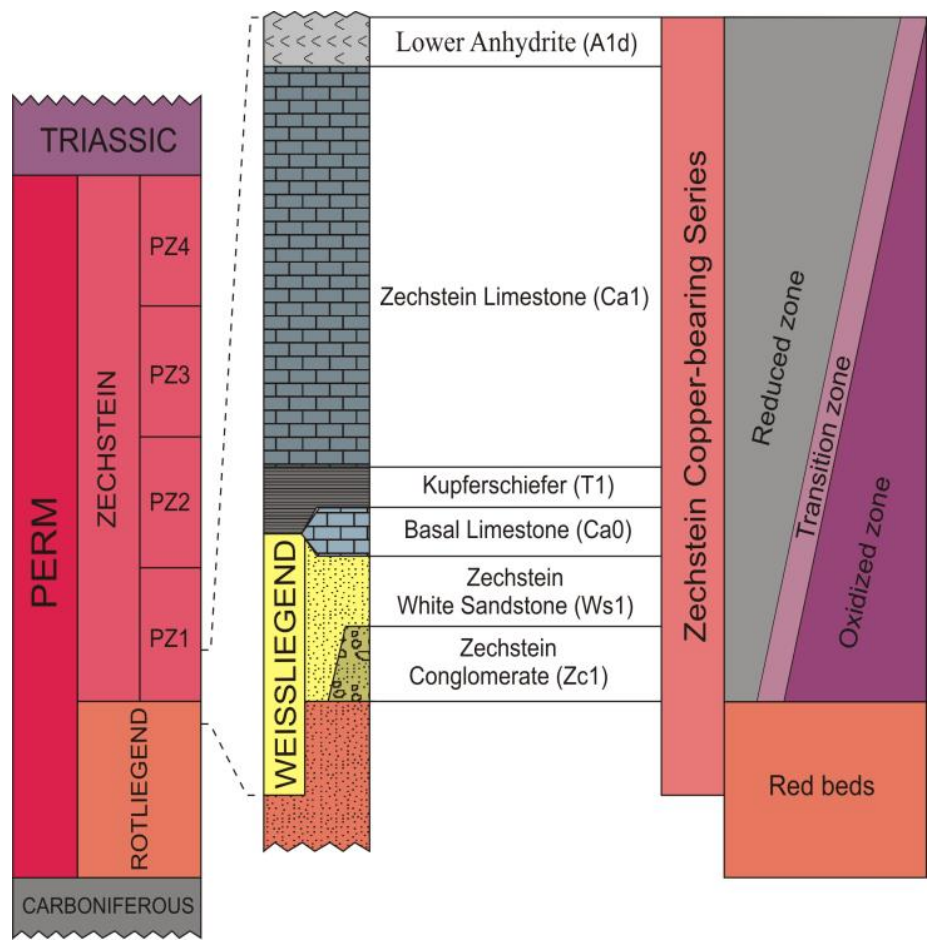

Figure 7. Stratigraphic position of the Zechstein copper-bearing series and distribution chart of geochemical zones that cut across the strata. 
The Zechstein copper-bearing series is developed in two geochemical magnafacies, namely as dark-grey organic matter-rich, metal sulfide-containing deposits (reduced zone, Figure 8A-D), and as red-colored, organic matter-deficient, hematite-bearing sediments (oxidized zone = Rote Fäule hematitic footwall alteration) (Figure $8 \mathrm{E}$ ). The redox interface, both vertically and horizontally, separates oxidized rocks, barren in $\mathrm{Cu}$ and $\mathrm{Ag}$, from reduced rocks with ore mineralization [54]. The highest grade $\mathrm{Cu}$ mineralization closely surrounds the oxidized areas.
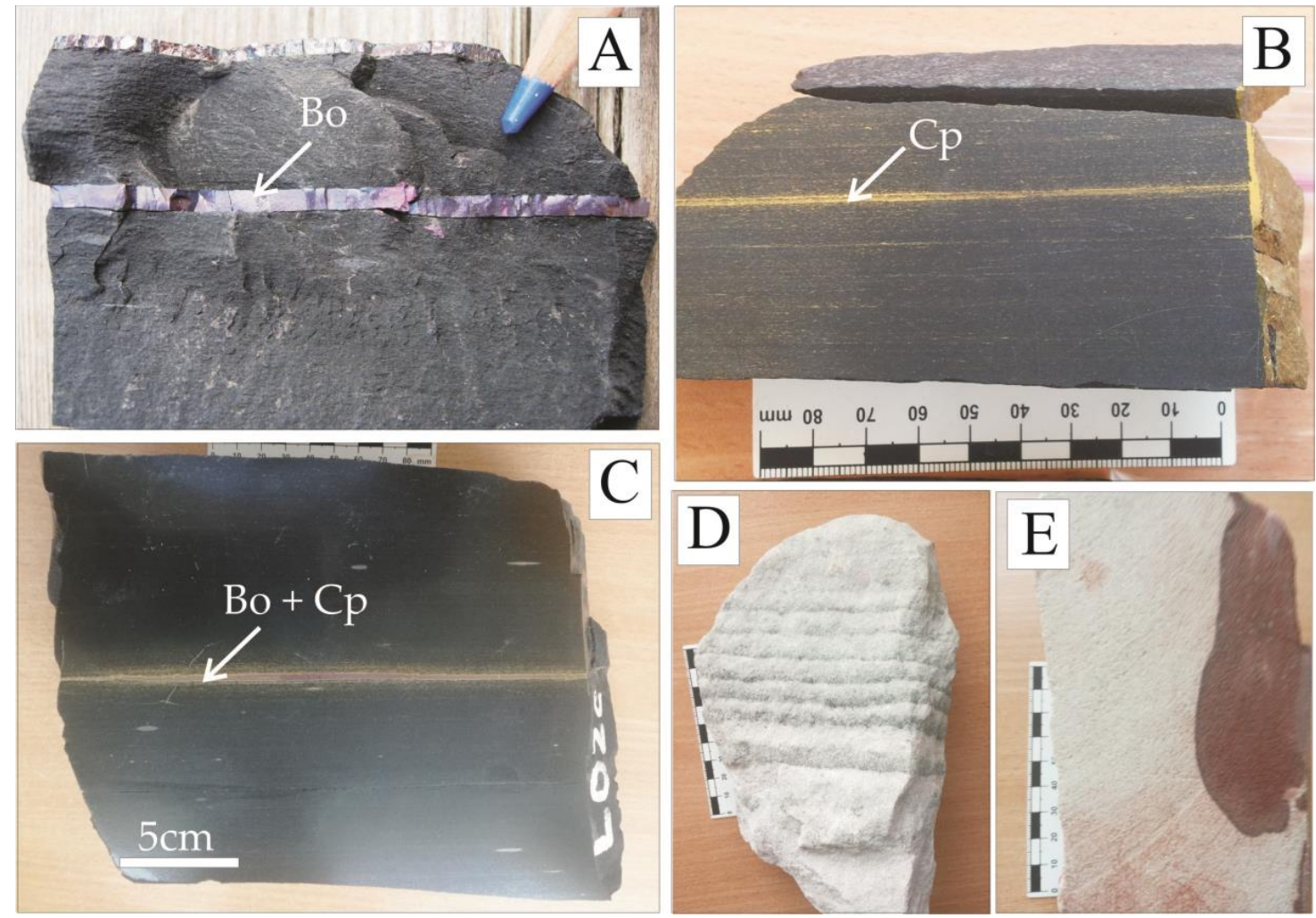

Figure 8. (A-C) Typical black shale (Kupferschiefer) ore with bornite (Bo) and chalcopyrite (Cp) veinlet and dissemination, (D) Weissliegend sandstone with very characteristic chalcocite lamination, and (E) red-spotted sandstones (Rote Fäule). All samples from the Lubin mine.

\section{Ore Mineralization}

The $\mathrm{Cu}$-Ag deposit contains ore mineralization consisting of fine-grained copper sulfides that occur as stratiform to stratabound disseminations in siliciclastic, shale, and carbonate rocks [52,53,55-59]. The ores form a peneconformable blanket-type deposit with large continuity. Copper mineralization is transgressive to bedding relative to the Rote Fäule front (Figure 7). The main ore minerals are chalcocite $\mathrm{Cu}_{2} \mathrm{~S}$, digenite $\mathrm{Cu}_{9} \mathrm{~S}_{5}$, covellite $\mathrm{CuS}$ (Figure 9), djurleite $\mathrm{Cu}_{31} \mathrm{~S}_{16}$, bornite $\mathrm{Cu}_{5} \mathrm{FeS}_{4}$, and chalcopyrite $\mathrm{CuFeS}_{2}$ with lesser tennantite $(\mathrm{Cu}, \mathrm{Fe})_{12} \mathrm{As}_{4} \mathrm{~S}_{13}$ and minor anilite $\mathrm{Cu}_{7} \mathrm{~S}_{4}$, roxbyite $\mathrm{Cu}_{9} \mathrm{~S}_{5}$, spionkopite $\mathrm{Cu}_{39} \mathrm{~S}_{28}$, yarrowite $\mathrm{Cu}_{9} \mathrm{~S}_{8}$, geerite $\mathrm{Cu}_{8} \mathrm{~S}_{5}$, idaite $\mathrm{Cu}_{5} \mathrm{FeS}_{6}$, mooihoekite $\mathrm{Cu}_{9} \mathrm{Fe}_{9} \mathrm{~S}_{16}$, and haycockite $\mathrm{Cu}_{4} \mathrm{Fe}_{5} \mathrm{~S}_{8}$ [52,54-59]. The main sulfides are commonly accompanied by Fe sulfides, galena, and sphalerite. Silver occurs in the form of own minerals (native silver, electrum, stromeyerite $\mathrm{AgCuS}$, naumannite $\mathrm{Ag}_{2} \mathrm{Se}$, mckinstrite $(\mathrm{Ag}, \mathrm{Cu})_{2} \mathrm{~S}$, jalpaite $\mathrm{Ag}_{3} \mathrm{CuS}_{2}$, chlorargyrite $\mathrm{AgCl}$, eugenite $\mathrm{Ag}_{9} \mathrm{Hg}_{2}$, and silver alloys, mostly amalgams) but the most important silver carriers are copper sulfides, bornite (up to about $15 \%$ by weight $\mathrm{Ag}$ ) and, then, chalcocite (up to $1.13 \mathrm{wt} \%$ ); tennantite $(\mathrm{Cu}, \mathrm{Fe}){ }_{12} \mathrm{As}_{4} \mathrm{~S}_{13}$ and tetrahedrite $(\mathrm{Cu}, \mathrm{Fe})_{12} \mathrm{Sb}_{4} \mathrm{~S}_{13}$ (up to $2.4 \mathrm{wt} \%$ ); djurleite, digenite, and chalcopyrite (up to $0.4 \mathrm{wt} \%$ ); galena (up to $0.3 \mathrm{wt} \%$ ); sphalerite (up to $0.1 \% \mathrm{wt} \%$ ); and pyrite (up to $1.5 \% \mathrm{wt} \%$ ) [54-56,58-67]. 


\begin{tabular}{|l|l|l|l|l|l|}
\hline & $\begin{array}{c}\text { Rotte Fäule } \\
\text { Zone }\end{array}$ & $\begin{array}{c}\text { Transition } \\
\text { Zone }\end{array}$ & Copper Zone & $\begin{array}{c}\text { Lead-Zinc } \\
\text { Zone }\end{array}$ & Pyrite Zone \\
\hline Hematite & & & & \\
Covellite & & & \\
Chalcocite & & & & \\
Bornite & & & & \\
Chalcopyrite & & & & \\
Galena & & & & \\
Sphalerite & & & & \\
Pyrite & & & & \\
\hline
\end{tabular}

Figure 9. Simplified paragenetic succession of ore mineralization from the $\mathrm{Cu}-\mathrm{Ag}$ Kupferschiefer deposits in Poland, modified after [53].

\section{Samples and Analytical Methods}

A total of 137 samples were subject to geochemical and mineralogical studies. Sixty-six samples of $\mathrm{Zn}-\mathrm{Pb}$ ores originated from the Silesia-Cracow district, and 71 from the $\mathrm{Cu}-\mathrm{Ag}$ Lubin-Sieroszowice Copper District. Representative samples for the MVT deposit were taken from several archive boreholes documenting seven sulfide deposits of $\mathrm{Zn}-\mathrm{Pb}$ in the Zawiercie region ( $\mathrm{Zn}-\mathrm{Pb}$ deposits at Gołuchowice, Zawiercie I and II, Marciszów, Poręba, Siewierz, and Rodaki-Rokitno Szlacheckie) and from three active mines in Olkusz, Pomorzany, and Klucze (Figure 10A). Among the representative samples of the Zechstein copper-bearing series, 62 samples came from archival drillings documenting the $\mathrm{Cu}-\mathrm{Ag}$ deposits on the Fore-Sudetic Monocline and nine samples from the active KGHiM mines. Samples from archival drilling cores concern the following $\mathrm{Cu}-\mathrm{Ag}$ deposits: Polkowice, Lubin-Małomice, Rudna, Radwanice-Gaworzyce, and Sieroszowice, (Figure 10B). The ore-grade economic intervals of drilling cores were examined for metal element content with a portable Olympus pXRF Delta spectrometer before sampling. In order to select and collect samples for geochemical analysis, over 1000 metal content measurements were made.

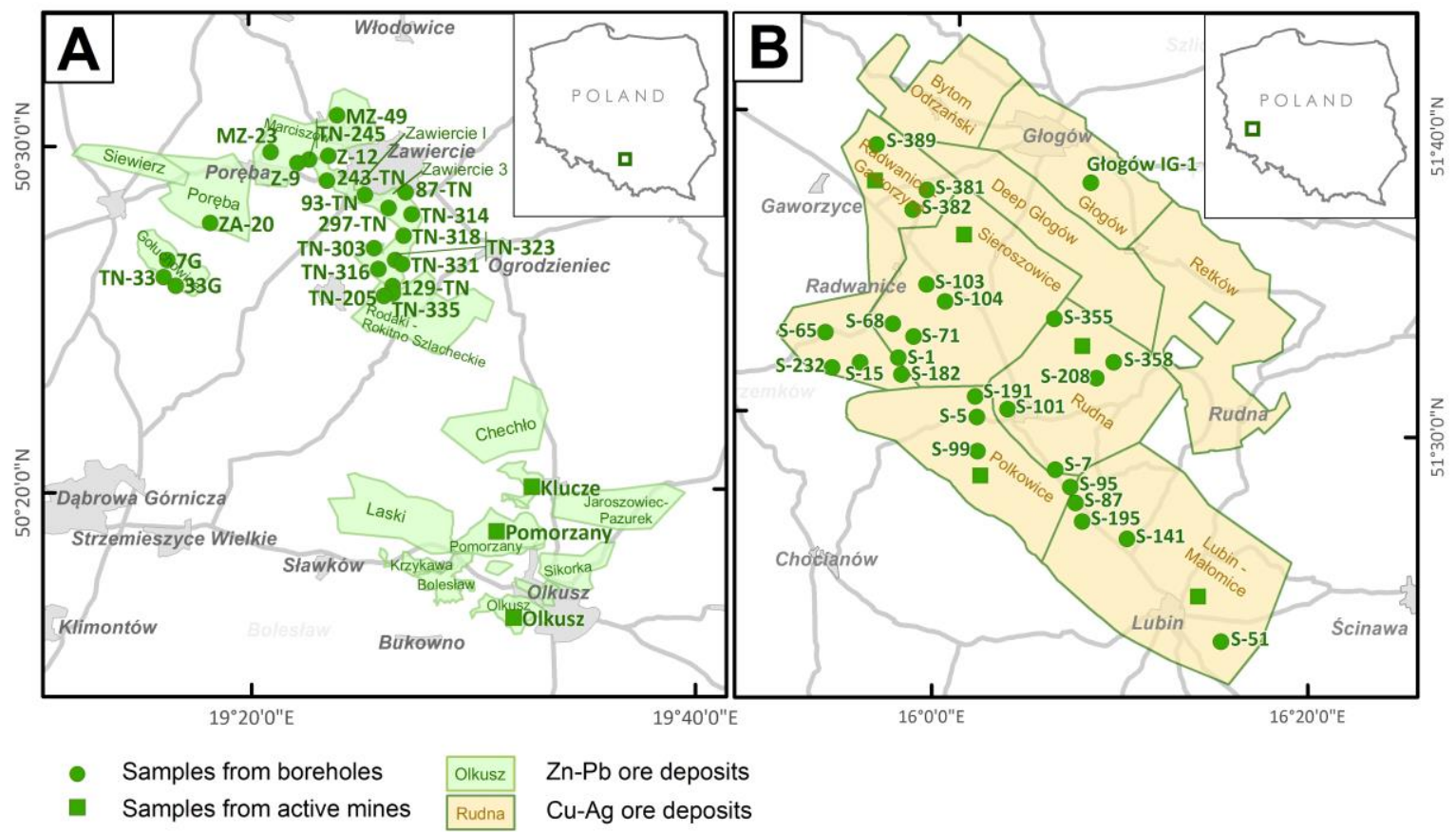

Figure 10. Location of boreholes sampled and studied in the $\mathrm{Zn}-\mathrm{Pb}(\mathbf{A})$ and $\mathrm{Cu}-\mathrm{Ag}(\mathbf{B})$ deposits. 
Chemical analyses in accordance with the international standard procedures were carried out at the Chemical Laboratory of Polish Geological Institute-National Research Institute in Warsaw, during the period of 2016 to 2018 [4].

The content of trace elements were determined in pressed powder samples (As, Ba, Bi, Br, $\mathrm{Cd}$, $\mathrm{Ce}, \mathrm{Co}, \mathrm{Cr}, \mathrm{Cu}, \mathrm{Ga}, \mathrm{Hf}, \mathrm{La}, \mathrm{Mo}, \mathrm{Nb}, \mathrm{Ni}, \mathrm{Pb}, \mathrm{Rb}, \mathrm{Sn}, \mathrm{Sr}, \mathrm{Th}, \mathrm{U}, \mathrm{V}, \mathrm{Y}, \mathrm{Zn}$, and $\mathrm{Zr}$ ) and in fused samples from the $\mathrm{Zn}-\mathrm{Pb}$ deposits the main compositions $\left(\mathrm{SiO}_{2}, \mathrm{TiO}_{2}, \mathrm{Al}_{2} \mathrm{O}_{3}, \mathrm{Fe}_{2} \mathrm{O}_{3}, \mathrm{MnO}, \mathrm{MgO}, \mathrm{CaO}, \mathrm{Na}_{2} \mathrm{O}\right.$, $\mathrm{K}_{2} \mathrm{O}, \mathrm{P}_{2} \mathrm{O}_{5}, \mathrm{SO}_{3}, \mathrm{Cl}$, and $\mathrm{F}$ ) were determined. Analyses were performed by wavelength dispersive X-ray fluorescence spectrometry (WD-XRF) method using a Philips PW-2400 spectrometer (Philips, Amsterdam, the Netherlands). The conditions of WD-XRF measurements for major oxides and trace elements were as follows: source of radiation, X-ray tube with $\mathrm{Rh}$ anode $(3 \mathrm{~kW})$; analyzing crystals LiF 200, PE, Ge, and PX1; collimators $0.15 \mathrm{~mm}$ and $0.30 \mathrm{~mm}$; and detectors scintillation counter, flow proportional counter $(\mathrm{Ar} / \mathrm{CH} 4)$, and Xe-sealed proportional counter. It should be noted that in the samples at high values of some elements such as $\mathrm{Zn}(>10,000 \mathrm{ppm}), \mathrm{Ba}(>4000 \mathrm{ppm})$, and Pb (>6000 ppm) there are serious interferences that appear in the spectra, which consequently causes an increase in the measured content of some other elements. These effects were not corrected because the content of interfering elements in many of the test samples significantly exceeds (one to two orders of magnitude) their content in the certified materials used to validate the method and it was not possible to determine appropriate correction factors. This is clearly visible in the case of a high concentration of $\mathrm{Ba}$ where the concentration of $\mathrm{V}$ is incorrectly increased, and in the case of $\mathrm{Pb}$ (galena) ores an uncorrected increase in $\mathrm{Cr}$ content. Results of $\mathrm{Cr}$ and $\mathrm{V}$ content determined by WD-XRF method were omitted in the article.

The content of rare earths (Sc, Y, La, Ce, Pr, Nd, Eu, Sm, Gd, Tb, Dy, Ho, Er, Tm, Yb, and Lu) and trace elements (Ag, As, Bi, Cd, Co, Cu, Hf, In, Mn, Mo, Ni, Nb, Re, Sb, Se, Sn, Ta, Te, Th, Tl, $\mathrm{W}$, and V) were determined after decomposition with a full mixture of $\mathrm{HCl}, \mathrm{HNO}_{3}, \mathrm{HF}$, and $\mathrm{HClO}_{4}$ acids using a Perkin Elmer ICP-MS Elan DRC II (Perkin Elmer SCIEX Instruments, Waltham, MA, USA) mass spectrometer by means of the inductively coupled plasma mass spectrometry (ICP-MS). The combination of organic carbon, silicates, and sulfides present in mineralized Kupferschiefer poses significant difficulties in quantitative chemical bulk-rock analysis [68]. As demonstrated by laboratory studies that compared the results of the chemical bulk-rock analyses of Kupferschiefer using various analytical methods (e.g., WD-XRF and instrumental neutron activation analysis, INAA), the results obtained can vary in the range of several to tens of percent for some elements [68]. However, Rahfeld et al. [68] mentioned that they obtained accurate results by a combination of INAA and multiple-step digestion procedures with ICP-MS, which was a case with our samples, which underwent multiple-step digestion procedures with ICP-MS.

$\mathrm{Au}, \mathrm{Pd}$, and Pt were measured using a Perkin Elmer model 4100 ZL spectrometer by graphite furnace atomic absorption spectrometry (GF AAS) method). Gold samples were preroasted and reconstituted with a mixture of $\mathrm{HCl}$ and $\mathrm{HNO}_{3}$ acids. Liquid-liquid extraction to methyl isobutyl ketone (MIBK) was used to separate the matrix and concentrate the test solution. The platinum and $\mathrm{Pd}$ samples were digested with aqua regia, and then $\mathrm{Pt}$ and $\mathrm{Pd}$ were isolated on activated carbon using formic acid.

Mercury was measured only in samples from $\mathrm{Cu}$-Ag deposits with application of atomic absorption spectrometer AMA-254 (Altec) with amalgamation technique (analyses were made directly from a solid sample) and in the case of extremely high mercury content by X-ray fluorescence spectrometry with wavelength dispersion (WD-XRF) using a Philips PW 2400 spectrometer (the analyses were performed with pressed powder samples). The lower limits of detection by the above applied methods are presented in Table 1. 
Table 1. The minimum detection limits of element measurements by applied methods.

\begin{tabular}{|c|c|c|c|c|c|c|c|c|c|c|c|c|}
\hline \multicolumn{13}{|c|}{ WD-XRF [ppm] } \\
\hline As & $\mathrm{Ba}$ & $\mathrm{Bi}$ & $\mathrm{Br}$ & $\mathrm{Cd}$ & $\mathrm{Ce}$ & Co & $\mathrm{Cr}$ & $\mathrm{Cu}$ & $\mathrm{Ga}$ & Hf & $\mathrm{La}$ & Mo \\
\hline 3 & 10 & 3 & 1 & 3 & 5 & 3 & 5 & 5 & 3 & 3 & 5 & \\
\hline $\mathrm{Nb}$ & $\mathrm{Ni}$ & $\mathrm{Pb}$ & $\mathrm{Rb}$ & Sn & $\mathrm{Sr}$ & Th & $\mathrm{U}$ & V & $\mathrm{Y}$ & $\mathrm{Zn}$ & $\mathrm{Zr}$ & 2 \\
\hline 2 & 3 & 3 & 3 & 2 & 2 & 3 & 2 & 5 & 3 & 2 & 3 & \\
\hline \multicolumn{8}{|c|}{ ICP-MS [ppm] } & \multicolumn{3}{|c|}{ GF AAS [ppm] } & \multicolumn{2}{|c|}{ AMA254 [ppm] } \\
\hline Sc & $\mathrm{Y}$ & $\mathrm{La}$ & $\mathrm{Ce}$ & $\operatorname{Pr}$ & $\mathrm{Nd}$ & $\mathrm{Eu}$ & $\mathrm{Sm}$ & $\mathrm{Au}$ & $\mathrm{Pd}$ & $\mathrm{Pt}$ & \multicolumn{2}{|c|}{$\mathrm{Hg}$} \\
\hline 0.5 & 0.5 & 0.5 & 0.5 & 0.5 & 0.5 & 0.05 & 0.05 & & & & \multirow{2}{*}{\multicolumn{2}{|c|}{0.001}} \\
\hline $\mathrm{Gd}$ & $\mathrm{Tb}$ & Dy & Ho & Er & $\mathrm{Tm}$ & $\mathrm{Yb}$ & $\mathrm{Lu}$ & 0.001 & 0.005 & 0.01 & & \\
\hline 0.05 & 0.05 & 0.05 & 0.05 & 0.05 & 0.05 & 0.05 & 0.05 & & & & & \\
\hline \multicolumn{13}{|c|}{ ICP-MS [ppm] } \\
\hline $\mathrm{Ag}$ & $\mathrm{Cd}$ & In & $\mathrm{Mn}$ & $\operatorname{Re}$ & $\mathrm{Sb}$ & Se & Sn & Тa & $\mathrm{V}$ & $\mathrm{Te}$ & $\mathrm{Tl}$ & $\mathrm{W}$ \\
\hline 0.1 & 0.5 & 0.05 & 1 & 0.05 & 0.5 & 2 & 1 & 0.05 & & & & \\
\hline As & $\mathrm{Bi}$ & Co & $\mathrm{Cu}$ & $\mathrm{Hf}$ & $\mathrm{Ni}$ & $\mathrm{Nb}$ & Mo & Th & 5 & 0.5 & 0.05 & 0.1 \\
\hline 2 & 0.05 & 0.5 & 0.5 & 0.05 & 0.5 & 0.5 & 0.5 & 0.05 & & & & \\
\hline \multicolumn{13}{|c|}{ WD-XRF [\%] } \\
\hline $\mathrm{SiO}_{2}$ & $\mathrm{TiO}_{2}$ & $\mathrm{Al}_{2} \mathrm{O}_{3}$ & $\mathrm{Fe}_{2} \mathrm{O}_{3}$ & $\mathrm{MnO}$ & $\mathrm{MgO}$ & $\mathrm{CaO}$ & $\mathrm{Na}_{2} \mathrm{O}$ & $\mathrm{K}_{2} \mathrm{O}$ & $\mathrm{P}_{2} \mathrm{O}_{5}$ & $\mathrm{SO}_{3}$ & $\mathrm{Cl}$ & $\mathrm{F}$ \\
\hline 0.1 & 0.01 & 0.05 & 0.01 & 0.001 & 0.01 & 0.01 & 0.01 & 0.01 & 0.001 & 0.01 & 0.001 & 0.01 \\
\hline
\end{tabular}

The basic statistical parameters (arithmetic mean, geometric mean, median, and standard deviation) of the content of elements in bulk-rock samples from $\mathrm{Zn}-\mathrm{Pb}$ and $\mathrm{Cu}-\mathrm{Ag}$ deposits were determined, as well as the correlation matrices between elements in the considering deposits. The degree of correlation of parameters was interpreted as follows: $r=0$ to 0.3 no correlation, $r=0.3$ to 0.5 very weak correlation, $r=0.5$ to 0.7 weak correlation, $r=0.7$ to 0.9 strong correlation, and $r \geq 0.9$ very strong correlation.

Datasets containing values below the limit of detection (LD) can lead to underestimates or overestimates of both the mean value and standard deviation, and therefore to correct this influence the statistical substitution methods was adopted [69] which is commonly used to replace a value below minimum limit of detection with a value equal to half the limit of detection (LD/2). In our bulk-rock geochemistry statistics we consider sample population of specific element only in the case when the number of samples with values above low detection limit constitute at least $75 \%$ and other values were treated as $\mathrm{LD} / 2$.

Detailed mineralogical and petrographic examinations together with photomicrographic documentation were carried out on a NIKON ECLIPSE LV100 POL (NIKON, Tokyo, Japan) microscope containing NIS-Elements software (Version 3.0). Quantitative examination of ore minerals on the X-ray microscope CAMECA SX-100 were preceded by preliminary investigation using the LEO-1430 (Obekochen, Germany) electron microscope (ZEISS) with an EDS (energy-dispersive $X$-ray spectroscopy) detector. Electron microprobe analysis (EPMA) was performed using a Cameca SX-100 (Gennevilliers, Cedex, France) microprobe equipped with five wavelength dispersive X-ray spectrometers (WDS). Determination of low concentrations in small phases with an electron microprobe is not straightforward and uncertainties differ for each acceleration voltage, counting statistics, background subtraction, sample heterogeneity, beam drift and other analytical reasons (e.g., stray X-rays and surface contamination). Although the precision of a single measurement for a given element was different due to the specificity of the method, it was possible to determine the variability of measurement precision. It was from about two hundred to one to three thousand ppm. In the case of main component of minerals, for example, in sphalerite the range of measurement precision variations were as the following: 250 to $330 \mathrm{ppm}$ for S, 1650 to $1900 \mathrm{ppm}$ for $\mathrm{Zn}$, and 580 to $800 \mathrm{ppm}$ for Fe. In galena were in the range 200-320 ppm for $\mathrm{S}$ and 2200-2900 ppm for Pb. In turn, for trace elements, such as $\mathrm{Cd}$ and $\mathrm{Ag}$ in sphalerite, variations in measurement precisions were from 280 to $1250 \mathrm{ppm}$ 
(average about 700 ppm) and from 700 to 1050 ppm (average about 800 ppm). In the Kupferschiefer samples the precision of single measurements within Ag-bearing copper minerals (chalcocite, djurleite, geerite, digenite, yarrovite, spionkopite, bornite, and chalcopyrite) varied in the range 730-970 ppm. The statistics of elements presented in this article include values above or close to the level of precision of a single measurement. The measurement statistics showed a large heterogeneity of the studied populations with a low level of confidence.

The following parameters were used during the EPMA analyses: HV accelerating voltage $15 \mathrm{kV}$, beam current $20 \mathrm{nA}$, and focused beam $(<1 \mu \mathrm{m}$ in diameter); acquisition times at the peak position $20 \mathrm{~s}$, at the background position $10 \mathrm{~s}$, and carbon sputtering; used international (commercial) standards from the SPI-53 set from SPI and from the sulf-16 set from P\&H: Chalcopyrite $=\mathrm{Cu}: 34.63 \%$, Fe: $30.43 \%$, S: 34.94\%; HgTe semicond = Hg: 61.2201\%, Te: 38.7799\%; Hessite $\mathrm{Ag}_{2} \mathrm{Te}=\mathrm{Ag}: 62.8352 \%$, Te: $37.1648 \%$; Gold = Au: 100\%; Co, As-Scooterrudite; $\mathrm{Sb}_{-} \mathrm{Sb}_{2} \mathrm{~S}_{3}$ Antimonite; Sb metal = Sb: 100\%; Ni-Ni metal; Hg-Cinnabar HgS = Hg: 86.22\%, S: 13.78\%; Cd-synthetic CdS = Cd: 77.8085\%, S: 22.1915\%; Vanadinite standard $=\mathrm{Pb}: 73.1495 \%, \mathrm{Cl}: 2.5033 \%$, V: $10.7906 \%$, O: 13.5566\%; Galena = S: $13.4 \%, \mathrm{~Pb}: 86.6 \%$; Zn-ZnS synthetic sphalerite $=$ Zn: 67.1\%, S: 32.9\%; ZnSe = Zn: 45.2958\%, Se: 54.7042\%; Arsenopyrite FeAsS = Fe: 34.44\%, As: 44.83\%, S: 20.73\%; Pentlandite = S: 33.01\%, Fe: 30.77\%, Co: 0.1\%, Ni: 36.12\%; Cobaltite $=$ Co: $20.59 \%$, As: $41.72 \%$, S: 22.2\%, Fe: 8.03\%, Ni: 7.46\%; Pyrite = Fe: 46.552\%, S: 53.448\%; InAs synthetic; Celsian = Ba: 37.23\%, Al: 14.26\%, Si: 14.6\%, O: 33.7\%, K: 0.22\%; Wollastonite = O: $41.17 \%$, Na: $0.01 \%$, Mg: 0.01\%, Si: 23.99\%, Ca: 34.17\%, Ti: 0.01\%, Mn: 0.49\%, Fe: 0.15\%; Periclase $=$ Mg: $60.3028 \%$, O: 39.6972\%. Signal(s) used: Si K $\alpha, \mathrm{Al} \mathrm{K} \alpha, \mathrm{S} \mathrm{K} \alpha, \mathrm{Te} L \alpha, \mathrm{Ca} K \alpha, \mathrm{Cd} \operatorname{L} \alpha, \mathrm{Ag} \mathrm{L} \alpha, \mathrm{Sb} \mathrm{L} \alpha, \mathrm{Cl}$ $\mathrm{K} \alpha, \mathrm{Pb} \mathrm{M} \beta$, Zn K $\alpha$, Se $\mathrm{L} \beta$, As $\mathrm{L} \beta, \mathrm{Cu} \mathrm{K} \alpha$, Ni K $\alpha$, Co K $\alpha$, Fe K $\alpha, \mathrm{Mg} \mathrm{K} \alpha, \mathrm{Hg} M \beta$, Au M $\alpha$, In L $\alpha$. To obtain best results original CAMECA software and procedures were used for a final correction of all measured elements. However, for some pairs of elements, overlapping of peaks occurred (e.g., $\mathrm{Pb}$ and $\mathrm{Au}$ in galena), which caused problems, and in many cases remain unresolved due to the limitations of the EPMA.

\section{Results}

\subsection{Zn-Pb Mississippi Valley-Type Deposits}

\subsubsection{Results of Bulk-Rock Geochemical Investigation}

Sixty-six sulfide ore samples were taken from 22 archival boreholes documenting seven deposits in the Zawiercie region and from three active mines in Olkusz, Pomorzany, and Klucze I (Figure 10A). The only produced commodities are $\mathrm{Zn}$ and $\mathrm{Pb}$. Geochemical study of the $\mathrm{Zn}-\mathrm{Pb}$ ores suggests that the arithmetic mean for zinc is $7.4 \%(n=66$ and standard deviation (s.d.) $=7.5 \%$, Table 2$)$ and for $\mathrm{Pb}$ about $3.6 \%$ (s.d. $=10.9 \%$ ). Most samples contain up to $5 \% \mathrm{Zn}$ (about $60 \%$ of the population, Figure $11 \mathrm{~A}-\mathrm{C}$ ) and $\mathrm{Zn}$ values from $5 \%$ to $20 \%$ accounts for about $40 \%$ of the sample population. The arithmetic mean of $\mathrm{Ag}$ is $13.4 \mathrm{ppm}(n=66$ and s.d. $=16.4 \mathrm{ppm})$ and the range varies from 0.9 to $102.7 \mathrm{ppm}$ (Figure 11C). About $30 \%$ of the population contain from 10 to $20 \mathrm{ppm} \mathrm{Ag}(n=23)$. Cadmium concentrations are usually between 200 and $400 \mathrm{ppm}(n=19)$ and only about $10 \%$ of samples have Cd content $>1000 \mathrm{ppm}$ (Figure 11D,E). The arithmetic mean is $440.2 \mathrm{ppm}(n=66$ and s.d. $=445.3 \mathrm{ppm})$. There is a strong positive correlation between $\mathrm{Zn}$ and $\mathrm{Cd}$ distribution in ores (correlation coefficient $\mathrm{r}=0.90$, Table 3) and a variable positive correlation between $\mathrm{Zn}-\mathrm{Cu}(\mathrm{r}=0.61), \mathrm{Zn}-\mathrm{Ga}(\mathrm{r}=0.56)$, and $\mathrm{Zn}-\mathrm{Ag}(\mathrm{r}=0.51)$, as well as between $\mathrm{Pb}$ and $\mathrm{U}(\mathrm{r}=0.86)$ and $\mathrm{Ga}(\mathrm{r}=0.61$, Figure 11F). 
Table 2. Basic statistical parameters for trace elements and main commodities $(\mathrm{Zn}$ and $\mathrm{Pb}$ ) (in ppm) of the bulk-rock samples from $\mathrm{Zn}-\mathrm{Pb}$ MVT deposits in Poland.

\begin{tabular}{|c|c|c|c|c|c|c|c|}
\hline Element & Number of Sample & $\begin{array}{l}\text { Arithmetic } \\
\text { Mean }\end{array}$ & $\begin{array}{c}\text { Geometric } \\
\text { Mean }\end{array}$ & Median & $\begin{array}{c}\text { Minimum } \\
\text { Content }\end{array}$ & $\begin{array}{c}\text { Maximum } \\
\text { Content }\end{array}$ & $\begin{array}{l}\text { Standard } \\
\text { Deviation }\end{array}$ \\
\hline As & 64 & 205.7 & 13.9 & 5 & $<3$ & 2609 & 453.9 \\
\hline $\mathrm{Ba}$ & 64 & $11,271.2$ & 133.2 & 43 & 5 & 117,347 & $25,975.2$ \\
\hline $\mathrm{Cd}$ & 66 & 440.2 & 246.5 & 298 & 14 & 2100 & 445.3 \\
\hline Co & 63 & 5.5 & 3.8 & 4 & $<3$ & 25 & 5.4 \\
\hline $\mathrm{Cu}$ & 66 & 56.3 & 29 & 37.5 & 5 & 257 & 61.9 \\
\hline $\mathrm{Ga}$ & 63 & 44 & 22.3 & 31 & $<3$ & 177 & 43.9 \\
\hline Mn & 65 & 1562.1 & 1428.1 & 1308.9 & 627.3 & 3299.4 & 679.9 \\
\hline $\mathrm{Nb}$ & 63 & 7.3 & 6.5 & 6 & 3 & 24 & 4.3 \\
\hline $\mathrm{Ni}$ & 63 & 71.4 & 16.8 & 17 & $<3$ & 512 & 124.6 \\
\hline $\mathrm{Pb}$ & 66 & $36,815.1$ & 3240.9 & 3968 & 20 & 800,737 & $109,493.7$ \\
\hline $\mathrm{Rb}$ & 65 & 38.9 & 21.2 & 15 & 6 & 450 & 64.9 \\
\hline $\mathrm{Sr}$ & 64 & 221.3 & 104.4 & 61 & 34 & 1635 & 356.9 \\
\hline $\mathrm{U}$ & 63 & 6.6 & 5.9 & 6 & 3 & 22 & 3.7 \\
\hline $\mathrm{V}$ & 63 & 32.7 & 9.5 & 7 & $<5$ & 284 & 61.9 \\
\hline $\mathrm{Y}$ & 63 & 22.5 & 13.6 & 15 & $<3$ & 90 & 21.4 \\
\hline $\mathrm{Zn}$ & 66 & $73,820.4$ & $34,577.1$ & 47,912 & 973 & 303,530 & $74,596.5$ \\
\hline $\mathrm{Zr}$ & 66 & 70.8 & 32.9 & 33 & 4 & 821 & 117.9 \\
\hline $\mathrm{Ag}$ & 66 & 13.4 & 7.9 & 9.9 & 0.9 & 102.7 & 16.4 \\
\hline Mo & 66 & 2.9 & 1 & 0.9 & $<1$ & 45.1 & 8 \\
\hline Hf & 66 & 0.07 & 0.05 & 0.06 & $<0.05$ & 0.5 & 0.1 \\
\hline $\mathrm{Sb}$ & 66 & 23.4 & 6.5 & 9.8 & $<0.5$ & 225.1 & 38.1 \\
\hline Se & 66 & 3.5 & 2.5 & 3 & $<2$ & 18 & 3.1 \\
\hline W & 66 & 18.9 & 1.2 & 0.4 & $<0.1$ & 347.1 & 50.1 \\
\hline $\mathrm{Tl}$ & 66 & 7.6 & 2.7 & 2.7 & 0.14 & 109.6 & 18.6 \\
\hline Th & 66 & 0.34 & 0.24 & 0.27 & $<0.05$ & 1.9 & 0.3 \\
\hline Sc & 66 & 2.30 & 1.48 & 2.30 & $<0.05$ & 6.4 & 1.2 \\
\hline $\mathrm{La}$ & 66 & 1.8 & 1.3 & 1.4 & $<0.05$ & 11.6 & 1.6 \\
\hline $\mathrm{Ce}$ & 66 & 3.2 & 2.4 & 2.4 & $<0.05$ & 18.7 & 2.7 \\
\hline $\mathrm{Nd}$ & 66 & 1.6 & 1 & 1.2 & $<0.05$ & 10.1 & 1.4 \\
\hline $\mathrm{Sm}$ & 66 & 0.4 & 0.3 & 0.3 & $<0.05$ & 10.7 & 0.4 \\
\hline $\mathrm{Eu}$ & 66 & 0.08 & 0.06 & 0.07 & $<0.05$ & 0.5 & 0.1 \\
\hline $\mathrm{Gd}$ & 66 & 0.33 & 0.26 & 0.25 & $<0.05$ & 2.0 & 0.3 \\
\hline Dy & 66 & 0.28 & 0.22 & 0.22 & $<0.05$ & 1.6 & 0.2 \\
\hline $\mathrm{Er}$ & 66 & 0.14 & 0.11 & 0.11 & $<0.05$ & 0.8 & 0.1 \\
\hline $\mathrm{Yb}$ & 66 & 0.11 & 0.08 & 0.09 & $<0.05$ & 0.7 & 0.1 \\
\hline Element & $\begin{array}{c}\text { Number of Sample } \\
\text { below/above } \\
\text { detection limit }\end{array}$ & $\begin{array}{c}\text { Arithmetic } \\
\text { Mean }\end{array}$ & $\begin{array}{c}\text { Geometric } \\
\text { Mean }\end{array}$ & Median & $\underset{\text { Content }}{\text { Minimum }}$ & $\begin{array}{c}\text { Maximum } \\
\text { Content }\end{array}$ & $\begin{array}{l}\text { Standard } \\
\text { Deviation }\end{array}$ \\
\hline $\operatorname{Pr}$ & $48 / 18$ & - & - & - & $<0.05 / 0.5$ & $<0.05 / 2.6$ & - \\
\hline $\mathrm{Tb}$ & $47 / 19$ & - & - & - & $<0.05 / 0.1$ & $<0.05 / 0.3$ & - \\
\hline Ho & $40 / 26$ & - & - & - & $<0.05 / 0.1$ & $<0.05 / 0.3$ & - \\
\hline $\mathrm{Tm}$ & $62 / 4$ & - & - & - & $<0.05 / 0.1$ & $<0.05 / 0.1$ & - \\
\hline $\mathrm{Lu}$ & $63 / 3$ & - & - & - & $<0.05 / 0.1$ & $<0.05 / 0.1$ & - \\
\hline $\mathrm{Bi}$ & $43 / 23$ & - & - & - & $<0.05 / 0.1$ & $<0.05 / 0.7$ & - \\
\hline $\mathrm{Br}$ & $39 / 24$ & - & - & - & $<0.5 / 1$ & $<0.5 / 13$ & - \\
\hline Sn & $28 / 38$ & - & - & - & $<0.5 / 1$ & $<0.5 / 5$ & - \\
\hline $\mathrm{Ta}$ & $55 / 11$ & - & - & - & $<0.05 / 0.1$ & $<0.05 / 0.7$ & - \\
\hline $\mathrm{Au}$ & $38 / 15$ & - & - & - & $<0.001 / 0.001$ & $<0.001 / 0.002$ & - \\
\hline $\mathrm{Pd}$ & $47 / 6$ & - & - & - & $<0.005 / 0.0012$ & $<0.005 / 0.01$ & - \\
\hline $\mathrm{Pt}$ & $50 / 3$ & - & - & - & $<0.01 / 0.001$ & $<0.01 / 0.001$ & \\
\hline
\end{tabular}

Note: In, $\operatorname{Re}$, and Te measured in the bulk-rock samples $(n=66)$ were below detection limit (for In and $\operatorname{Re}<0.05 \mathrm{ppm}$, and for Te $<0.5$ ppm) by ICP-MS. 

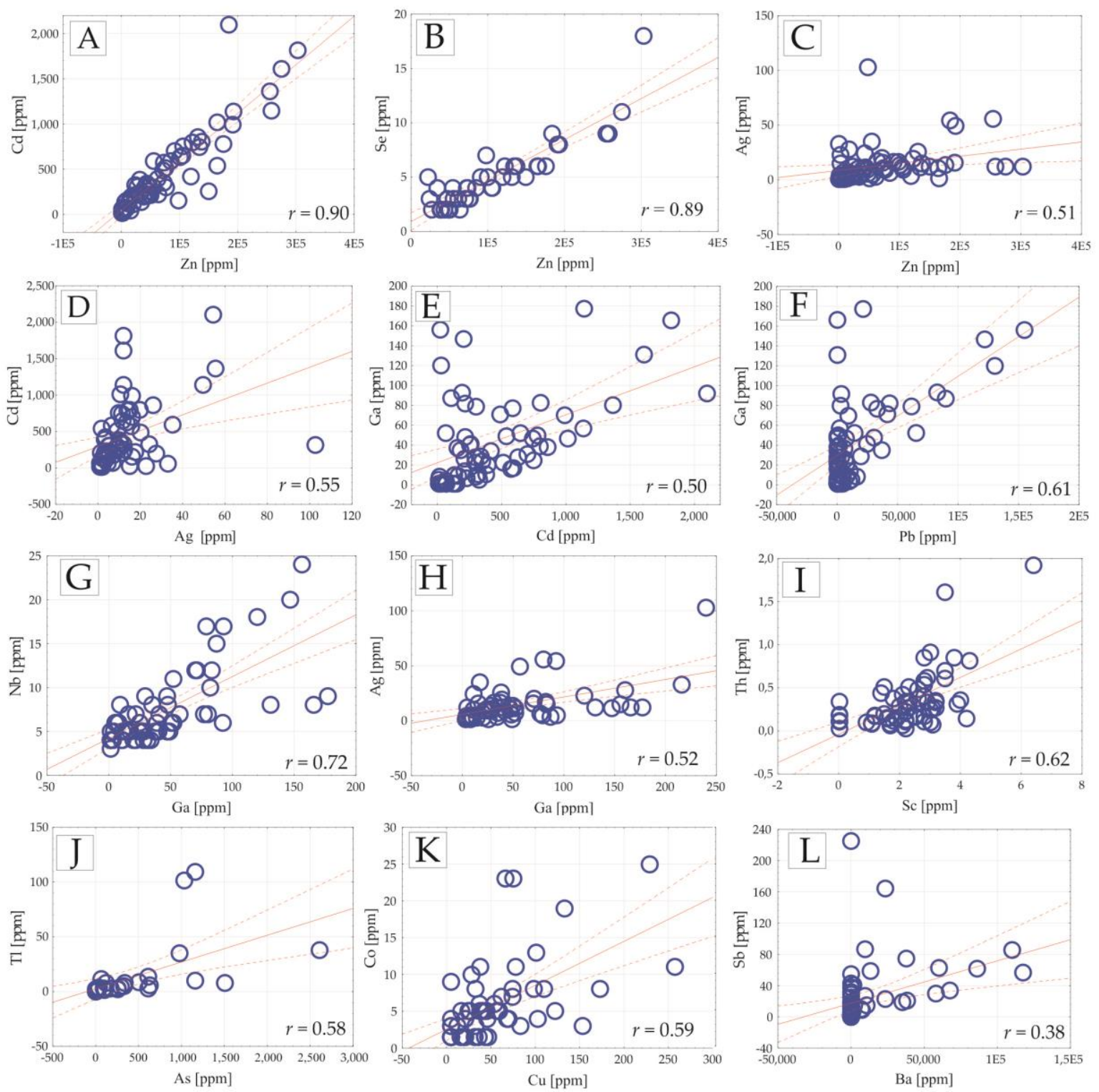

Figure 11. Bivariate plots of trace elements (ppm) in bulk-rock samples of $\mathrm{Zn}-\mathrm{Pb}$ ores from the MVT deposits in Poland: (A) Zn vs. Cd, (B) Zn vs. Se, (C) Zn vs. Ag, (D) Ag vs. Cd, (E) Cd vs. Ga, (F) Pb vs. Ga, (G) Ga vs. Nb, (H) Ga vs. Ag, (I) Sc vs. Th, (J) As vs. Tl, (K) Cu vs. Co, and (L) Ba vs. Sb. Note: 95\% confidence intervals are shown as the red dotted lines, while the line of best fit is shown as the red line. 
Table 3. Pearson's correlation coefficients of selected elements for the bulk-rock samples from Zn-Pb (MVT) deposits in Poland.

\begin{tabular}{|c|c|c|c|c|c|c|c|c|c|c|c|c|c|c|c|c|c|c|c|c|c|c|}
\hline & $\mathrm{Ag}$ & As & Ba & $\mathrm{Cd}$ & $\mathrm{Ce}$ & Co & $\mathrm{Cu}$ & Ga & Hf & La & Mo & $\mathrm{Nb}$ & $\mathrm{Ni}$ & $\mathrm{Pb}$ & $\mathrm{Sb}$ & Sc & Se & $\mathrm{Sr}$ & Th & $\mathrm{Tl}$ & $\mathbf{U}$ & W \\
\hline As & 0.24 & & & & & & & & & & & & & & & & & & & & & \\
\hline Ba & 0.03 & -0.10 & & & & & & & & & & & & & & & & & & & & \\
\hline $\mathrm{Cd}$ & 0.64 & 0.16 & 0.00 & & & & & & & & & & & & & & & & & & & \\
\hline $\mathrm{Ce}$ & -0.13 & -0.14 & -0.11 & 0.00 & & & & & & & & & & & & & & & & & & \\
\hline Co & 0.22 & 0.00 & 0.27 & 0.09 & 0.32 & & & & & & & & & & & & & & & & & \\
\hline $\mathrm{Cu}$ & 0.45 & 0.18 & 0.11 & 0.57 & 0.32 & 0.59 & & & & & & & & & & & & & & & & \\
\hline $\mathrm{Ga}$ & 0.33 & -0.11 & 0.38 & 0.50 & -0.10 & 0.30 & 0.40 & & & & & & & & & & & & & & & \\
\hline Hf & -0.03 & 0.00 & -0.04 & -0.05 & 0.71 & 0.33 & 0.26 & -0.12 & & & & & & & & & & & & & & \\
\hline La & -0.17 & -0.16 & -0.11 & -0.03 & 0.99 & 0.34 & 0.32 & -0.13 & 0.70 & & & & & & & & & & & & & \\
\hline Mo & -0.01 & 0.76 & -0.10 & 0.00 & -0.08 & -0.10 & -0.06 & -0.18 & -0.05 & -0.08 & & & & & & & & & & & & \\
\hline $\mathrm{Nb}$ & 0.11 & -0.11 & 0.68 & -0.05 & -0.10 & 0.40 & 0.13 & 0.72 & -0.03 & -0.11 & -0.08 & & & & & & & & & & & \\
\hline $\mathbf{N i}$ & 0.31 & 0.29 & 0.01 & 0.25 & 0.05 & 0.32 & 0.33 & 0.13 & 0.31 & 0.00 & -0.08 & 0.01 & & & & & & & & & & \\
\hline $\mathrm{Pb}$ & 0.00 & -0.22 & 0.48 & -0.27 & -0.19 & 0.28 & -0.06 & 0.61 & -0.14 & -0.18 & -0.14 & 0.92 & -0.12 & & & & & & & & & \\
\hline $\mathrm{Sb}$ & 0.16 & 0.03 & 0.38 & -0.06 & -0.01 & 0.35 & 0.17 & 0.37 & 0.12 & -0.02 & -0.01 & 0.52 & 0.45 & 0.46 & & & & & & & & \\
\hline Sc & 0.15 & 0.11 & -0.34 & 0.22 & 0.58 & 0.09 & 0.19 & -0.33 & 0.61 & 0.57 & 0.02 & -0.50 & 0.34 & -0.62 & -0.14 & & & & & & & \\
\hline Se & 0.47 & 0.16 & -0.02 & 0.88 & 0.04 & 0.09 & 0.59 & 0.52 & -0.06 & 0.00 & -0.06 & -0.07 & 0.29 & -0.28 & -0.08 & 0.19 & & & & & & \\
\hline $\mathrm{Sr}$ & 0.04 & -0.11 & 0.99 & 0.02 & -0.09 & 0.28 & 0.12 & 0.35 & 0.00 & -0.09 & -0.11 & 0.66 & 0.04 & 0.44 & 0.36 & -0.29 & -0.01 & & & & & \\
\hline Th & -0.06 & 0.01 & -0.15 & -0.12 & 0.79 & 0.30 & 0.25 & -0.16 & 0.93 & 0.76 & -0.04 & -0.08 & 0.26 & -0.15 & 0.12 & 0.62 & -0.10 & -0.12 & & & & \\
\hline $\mathrm{Tl}$ & -0.02 & 0.58 & -0.05 & 0.07 & -0.10 & -0.09 & -0.03 & -0.08 & -0.09 & -0.11 & 0.83 & -0.05 & 0.04 & -0.14 & 0.00 & 0.04 & 0.03 & -0.06 & -0.10 & & & \\
\hline $\mathbf{U}$ & 0.12 & -0.10 & 0.12 & -0.06 & -0.15 & 0.23 & 0.06 & 0.69 & -0.11 & -0.17 & -0.08 & 0.76 & -0.01 & 0.86 & 0.40 & -0.49 & -0.07 & 0.08 & -0.08 & -0.05 & & \\
\hline W & 0.13 & -0.05 & 0.32 & -0.01 & 0.25 & 0.77 & 0.47 & 0.27 & 0.16 & 0.29 & -0.05 & 0.40 & -0.04 & 0.35 & 0.15 & -0.15 & 0.01 & 0.30 & 0.14 & -0.08 & 0.24 & \\
\hline $\mathrm{Zn}$ & 0.51 & 0.19 & 0.02 & 0.90 & 0.02 & 0.11 & 0.60 & 0.56 & -0.01 & -0.03 & -0.07 & -0.03 & 0.36 & -0.26 & 0.01 & 0.25 & 0.93 & 0.03 & -0.07 & 0.09 & -0.04 & -0.03 \\
\hline
\end{tabular}

indicating for correlation coefficient interpreted as follows: $r=0.5$ to 0.7 weak correlation, $r=0.7$ to 0.9 strong correlation, and $r \geq 0.9$ very strong correlation. 
The elevated concentration of some critical elements, such as: Ga (Figure 11G,H), Hf, In, Sc (Figure 11I), and traces like $\mathrm{Tl}$ (Figure 11J) and Ag (Figure 11C) are also typical for the examined ores.

Particular attention is paid to the high arithmetic mean values for $\mathrm{Tl}$ and $\mathrm{Ga}(7.6 \mathrm{ppm}$ and $44 \mathrm{ppm}$, respectively, Table 2). Thallium concentrations range from 0.14 to $109.6 \mathrm{ppm}$, but $\mathrm{Tl}$, similar to $\mathrm{Cd}$, is a toxic and detrimental ore component from an environmental point of view. Gallium is present in the range from $1.5 \mathrm{ppm}$ to $177 \mathrm{ppm}$. Figure $11 \mathrm{H}$ shows that about $30 \%$ of the samples from the entire Ga population are in the range of up to $20 \mathrm{ppm}$. The rest samples (about 70\%) show Ga concentrations higher than $20 \mathrm{ppm}$. The distribution of $\mathrm{Ga}$, similar to $\mathrm{Cd}$, is associated predominantly with sphalerite $[28,29]$. About $70 \%$ of the population of the analyzed samples has a Co concentration below the arithmetic mean ( $5.5 \mathrm{ppm} \mathrm{Co}$ ) and only $5 \%$ of the population of samples contain Co in the range from 20 and $25 \mathrm{ppm}$ (Figure 11K). The arithmetic mean for Sc, $2.3 \mathrm{ppm}(n=66$ and s.d. $=1.2 \mathrm{ppm}$ ), is very low (almost three times lower relative to its abundance in the Earth's crust [70]). The concentrations of $\mathrm{Nb}$ in bulk-rock sulfide ores are low changing from 3 to $24 \mathrm{ppm}$ (arithmetic mean $=7.3 \mathrm{ppm}, n=63$, and s.d. $=4.3 \mathrm{ppm}$ ). On the other hand, $\mathrm{Ba}$ is associated with $\mathrm{Zn}-\mathrm{Pb}$ ores, and occurs locally in significant concentrations. Its content ranges from $5 \mathrm{ppm}$ to $11.73 \%$ (Figure 11L) and the arithmetic mean is $1.13 \%(n=64$ and s.d. $=2.59 \%)$. Approximately $20 \%$ of the investigated samples have Ba content above 1\%, what is very common at MVT deposits [5]. Barium is present in $\mathrm{Zn}-\mathrm{Pb}$ ores in the form of barite, which is classified in the EU as critical raw material. The correlation coefficient between $\mathrm{Ba}$ and $\mathrm{Pb}$ in bulk-rock samples is very weak $(\mathrm{r}=\sim 0.5)$.

Concentrations of other critical elements, including REE and PGE, in most of the bulk-rock samples are low. Within rare earth elements the highest arithmetic mean was for Ce (3.2 ppm, $n=66$, s.d. $=2.7 \mathrm{ppm}$, range from $<0.05$ to $18.7 \mathrm{ppm}$ ). The sum of light REE (LREE, from La to Ce) is very low and ranges from 1.5 to $30.3 \mathrm{ppm}$, and the arithmetic average is $5.1 \mathrm{ppm}(n=64)$. In turn, the sum of elements classified as middle (MREE, from Pr to Eu) and heavy REE (HREE, from Gd-Lu) is between 0.1 and $15.8 \mathrm{ppm}$ and 0.2 and $6.1 \mathrm{ppm}$, respectively (arithmetic mean $=2.3 \mathrm{ppm}$, and $1 \mathrm{ppm}$, respectively). Arithmetic mean of $\sum R E E=8.3 \mathrm{ppm}$. The LREE to MREE ratio is between 1 and 22.9 and the LREE to HREE ratio is between 1.6 and 12.3. Figure 12A shows concentrations of REE normalized to chondrite according to [70]. Primarily, clearly visible are very low, beneath the lower detecting level of ICP-MS method, contents of some REE such as $\mathrm{Pr}, \mathrm{Eu}, \mathrm{Tb}, \mathrm{Ho}, \mathrm{Tm}, \mathrm{Yb}$, and $\mathrm{Lu}$. On the chart is noted a weak enrichment of LREE and also a negative Eu anomaly and in over a dozen samples with a positive anomaly of Sm (Figure 12B). These positive Sm anomalies in 11 samples correspond with high barite contents in these samples. The highest Sm contents are two or three times higher than the contents of neighboring elements on the plot, for example, $\mathrm{Nd}$ and $\mathrm{Eu}$. The range of the highest Ba concentration is from 9439.0 to $117,347.0 \mathrm{ppm}$ and the Sm content range from 3.45 to $10.74 \mathrm{ppm}$, relatively.
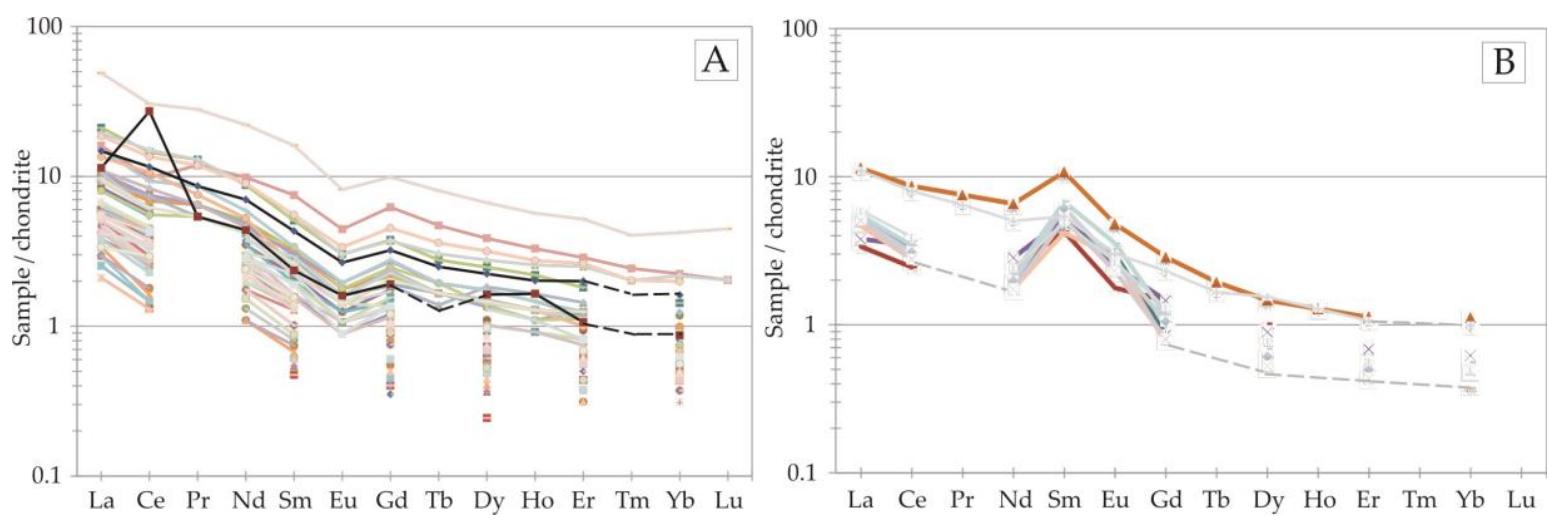

Figure 12. (A,B) Comparison of REE content plots in the bulk-rock analyses of $\mathrm{Zn}$-Pb sulfide ores and red galmans (Zn oxide ores, black line) from the MVT deposits in Poland: (A) Normalized to chondrite (according to [70]), note negative Eu (A) and positive Sm (B) anomalies. Positive Sm anomalies are due to high barite content in $\mathrm{Zn}-\mathrm{Pb}$ ore. 
Noteworthy are the REE contents in two samples of red galmans (Zn oxide ores, black lines on Figure 12A) from the outcrop near Bolesław. Samples of red galmans have $\mathrm{Zn}$ and $\mathrm{Pb}$ concentrations in the form of secondary, hydrated iron minerals (limonites) containing -3.7 and $50.1 \% \mathrm{Zn}$ and -0.41 and $1.5 \% \mathrm{~Pb}$, respectively. Galman samples are enriched in $\mathrm{Ga}(25 \mathrm{ppm}$ and $397 \mathrm{ppm})$, As $(0.3 \%$ and $751 \mathrm{ppm}$ ) and Hf (17 and $38 \mathrm{ppm}$, respectively). Red galman samples, relative to sulfide ores samples, are also enriched in some REE (Figure 12A). They also showed a negative Eu anomaly and in case of one sample there is a visible clear increase in Ce content. The REE enrichment in red galmans relative to chondrite is relatively small and a sum of LREE is 16 and $22.7 \mathrm{ppm}$, and $\sum H R E E=5.1$ and $3.2 \mathrm{ppm}$, respectively. The LREE/HREE ratio is about 3.2 and 7.2, respectively.

\subsubsection{Results of Mineralogical Investigation}

The ore mineralization is mainly represented by sphalerite-galena-pyrite/marcasite mineral assemblages (Figures 13 and 14). The studied core sections are intervals with identified economic resources of documented $\mathrm{Zn}-\mathrm{Pb}$ deposits made of carbonate rocks, mainly dolomites, clearly marked by macroscopic sulfide mineralization. Galena and sphalerite are the main ore minerals, commonly accompanied by pyrite and marcasite. They occur mainly as disseminations (Figure 13A,B), inclusions in rock matrix, crystal brushes on the surfaces of cracks (Figure 13B-E), in caverns (Figure 13C), and breccias (Figure 4F). The presence of cerussite was also found macroscopically, while willemite, anglesite, and hydrated weathering products of $\mathrm{Zn}-\mathrm{Pb}$ ores were identified by microprobe analyses. Ore mineralization is often accompanied by calcite in the form of crystal brushes or as cement for hydrothermal breccia (Figure 13F). In the Zawiercie $87 \mathrm{TN}$ borehole, there is a layered $\mathrm{Zn}$ ore with zebra texture (Figure 13C). Sphalerite often occurs in the form of disseminated mineralization in the form of small ( $\leq 3 \mathrm{~mm}$ ), macroscopically visible honey-brown crystals (Figure 13E). Disseminated sphalerite was formed as a result of filling of the pore space in dolomite or crystallized as a result of metasomatism [20]. Sphalerite can also crystallize on the surface of cracks and caverns or appear as crystalline brushes, creating automorphic or hypautomorphic crystals of a few millimeters in size. In the samples taken from the Olkusz and Klucze deposits, sphalerite co-exist with galena and marcasite forming collomorphic textures (so-called zinc blende, Figure 4A-D). In addition, sphalerite is one of the components of the hydrothermal fractional cement in addition to galena (Figure 4F) and white calcite (Figure 13F). Microprobe analysis of the chemical composition showed that the chemical composition of sphalerite (e.g., Figure 14A-D) is characterized by arithmetic average $\mathrm{Zn}$ content of $65.95 \mathrm{wt} \%$ (s.d. $=0.66$ and $n=500$ ), and average $\mathrm{S}$ content of $32.58 \mathrm{wt} \%$ (s.d. $=0.42$ and $n=500$ ) (Table 4). Additionally, Fe and Cd concentrations in sphalerite are up to $2.48 \mathrm{wt} \%$ (average $=2600 \mathrm{ppm}$, s.d. $=4310 \mathrm{ppm}$, and $n=500)$ and $2.64 \mathrm{wt} \%$ (average $=3063 \mathrm{ppm}$ and s.d. $=3633 \mathrm{ppm}$, respectively, Figure 15B,D). In Figure 15A-C, the precision ranges of a single measurement for a given element in EPMA are marked with a dashed horizontal line. It is possible to recognize two Fe populations in sphalerites; the first one with moderate Fe contents $(>0.5 \mathrm{wt} \%)$ and the second one with low Fe contents $(<0.5 \mathrm{wt} \%)$. Nickel and Co range from hundreds ppm up to 910 and $810 \mathrm{ppm}$, respectively. Silver concentrations in sphalerite range from below detection limit to $3310 \mathrm{ppm}$ (arithmetic mean $219 \mathrm{ppm}$ and $n=500$ ) (Figure 15C) and $\mathrm{Cu}$ concentrations up to 10,470 ppm. Indium was detected only in a few sphalerite crystals (maximum $290 \mathrm{ppm}$ ), although it is reported as a trace component within sphalerite in many MVT-type world deposits [71-76]. According to previous studies, the ranges in concentrations of minor and trace elements in any ore minerals vary widely throughout the district as well as in the specific mines [28,29]. It was supported also by our investigation, in which we analyzed additionally, numerous samples from the undeveloped $\mathrm{Zn}$-Pd deposits from the Zawiercie region. The studied sphalerites, which represent the main ore stage in the mineral succession (second stage, see Figure 5), have a variable habit of crystals (granular, collomorphic, banded, and breccia cement) and content of $\mathrm{Fe}$, $\mathrm{Cd}$, and minor and trace elements (Figure 15B,C). For example, in sphalerite of the collomorphic type, the highest arithmetic mean content of Fe was found (Table 5). In turn, breccia cement sphalerites show 
the highest $\mathrm{Cd}$ admixtures (arithmetic mean $=5741 \mathrm{ppm}$, s.d. $=4530 \mathrm{ppm}$, and $n=9$ ), and granular sphalerites revealed a highest single content of $\mathrm{Ag}=3310 \mathrm{ppm}$ (Table 5).
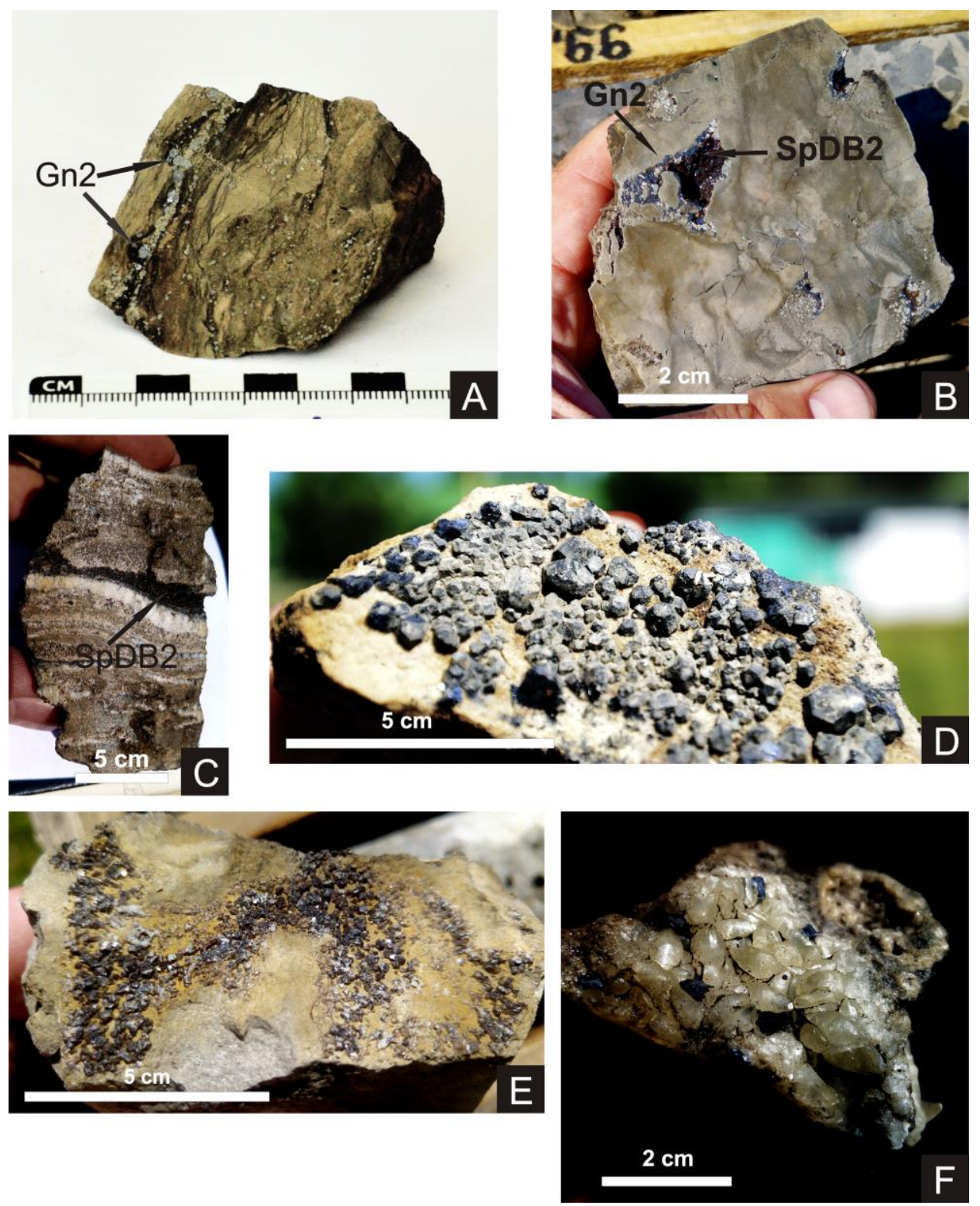

Figure 13. (A) Galena (Gn2) crystals within irregularly streaked dolomite, Zawiercie 93 TN borehole; (B) dolomite with visible unstable density layering structures, with many caverns partly filled with sphalerite and galena, Zawiercie TN 87 borehole; (C) stratified Zn-Pb ore, "zebra-type", Poręba MZ 23 borehole; (D) well-formed galena, in form of octahedrons and cubes, Gołuchowice 21 G borehole; (E) sphalerite crystallized on the cracked dolomite surface, Gołuchowice $2 \mathrm{G}$ borehole; and (F) galena and white calcite forming the matrix of hydrothermal breccia, Kierszula TN 245 borehole. 

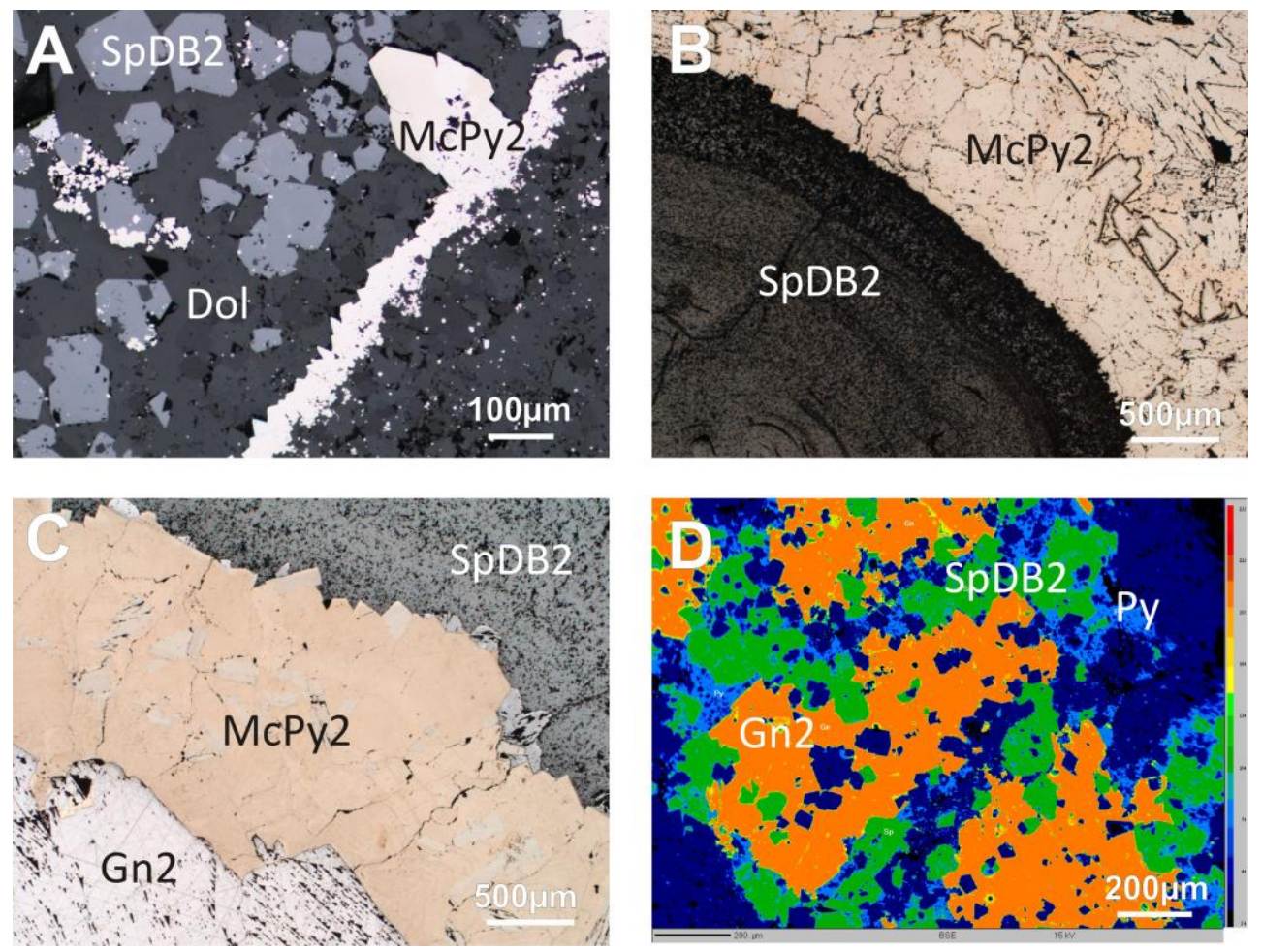

Figure 14. Photomicrographs of sphalerite-galena-marcasite ore from the $\mathrm{Zn}-\mathrm{Pb}$ (MVT) deposits in Poland: (A) Euhedral sphalerite (Sp) and marcasite (McPy2) scattered in ore-bearing dolomite (Dol), reflected light, Z9 borehole; (B) massive marcasite (McPy2) encrusted on colloform sphalerite (SpDB2), reflected light, the Pomorzany mine; (C) colloform texture of massive galena (Gn2), euhedral marcasite (McPy2), and porous sphalerite (SpDB2), sample from the Klucze I deposit, reflected light; and (D) automorphic crystals of galena (Gn2) overgrown by sphalerite (SpDB2) and pyrite (Py), backscattered-electron imaging BSEI, false colors (red, high values of BSEI brightness and dark blue, low values of BSEI brightness), TN-314 borehole.

Galena occurs in the form of macroscopically visible lead-gray, small grains in dolomite and crystals in caverns and fissures, displaying large euhedral crystals of the cube or octahedron forms, reaching up to $1 \mathrm{~cm}$ in size (Figure 13D). It occurs abundantly in the cement of hydrothermal breccia forming intergrowths with sphalerite and white calcite (Figure 13F). EPMA studies have revealed that galena has an average content of $\mathrm{Pb}(85.55 \mathrm{wt} \%$, s.d. $=0.52 \mathrm{wt} \%$, and $n=197)$ and $\mathrm{S}(13.39 \mathrm{wt} \%$ and s.d. $=0.15)($ Table 4$)$. In most of the analyzed samples, galena contains $\mathrm{Zn}$ concentrations of up to $0.84 \mathrm{wt} \%$. Antimony contents in galena are more varied from b.d.l. to $1.82 \mathrm{wt} \%$. Galena is a known $\mathrm{Ag}$ carrier, however, in the analyzed samples Ag was encountered sporadically, and its maximum content was below $730 \mathrm{ppm}$ (Table 4). Ag-rich galena is accompanied by either increased Sb or Bi contents, due to double substitution for $\mathrm{Pb}^{2+}$. The majority of Ni concentrations in galena show values up to $1280 \mathrm{ppm}$. Admixtures of $\mathrm{Co}$ are in the range of below detection limit to $1090 \mathrm{ppm}$, as well as $\mathrm{Cu}$ up to $1710 \mathrm{ppm}$, Fe up to $12,370 \mathrm{ppm}$, and As up to $4300 \mathrm{ppm}$ (Table 4). 
Table 4. Average EPMA analyses of sphalerite, galena, and pyrite/marcasite from the Zn-Pb (MVT) deposits in Poland.

\begin{tabular}{|c|c|c|c|c|c|c|c|c|c|c|c|c|c|c|c|c|c|c|c|c|c|}
\hline $\begin{array}{l}\text { Sphalerite }{ }^{* *} \\
\quad(n=500)\end{array}$ & $\mathrm{Zn}$ & $S$ & $\mathrm{Fe}$ & $\mathrm{Pb}$ & $\mathrm{Cd}$ & Ag & As & $\mathrm{Cu}$ & Co & $\mathrm{Sb}$ & $\mathrm{Ni}$ & $\mathrm{Au}$ & Se & $\mathrm{Te}$ & $\mathbf{B i}$ & $\mathrm{Hg}$ & $\mathrm{Cl}$ & $\mathrm{Ca}$ & $\mathrm{Mg}$ & $\mathrm{Si}$ & Total \\
\hline & $\mathrm{wt} \%$ & $\mathrm{wt} \%$ & wt $\%$ & wt $\%$ & ppm & ppm & ppm & ppm & ppm & ppm & ppm & ppm & ppm & ppm & ppm & ppm & ppm & ppm & ppm & ppm & wt. $\%$ \\
\hline Mean & 65.95 & 32.58 & 0.26 & 0.05 & 3063 & 219 & 165 & 400 & 205 & & & & & & & & 1513 & 248 & 366 & 201 & 99.56 \\
\hline S.D. & 0.66 & 0.42 & 0.43 & 0.103 & 3633 & 334 & 478 & 658 & 193 & & & & & & & & 1534 & 524 & 545 & 452 & 0.62 \\
\hline Min. & 62.96 & 30.27 & $\stackrel{*}{*}$ b.d.l. & b.d.l. & b.d.l. & b.d.l. & b.d.l. & b.d.l. & b.d.l. & b.d.l. & b.d.l. & b.d.l. & b.d.l. & b.d.l. & b.d.l. & b.d.l. & b.d.l. & b.d.l. & b.d.l. & b.d.l. & 98.14 \\
\hline Max. & 67.69 & 33.80 & 2.48 & 1.24 & 26,390 & 3310 & 5250 & 10,470 & 810 & 10,040 & 910 & & 1620 & 410 & 580 & 1250 & 8430 & 4590 & 5800 & 9850 & 101.44 \\
\hline \multirow{2}{*}{$\begin{array}{l}\text { Galena ** } \\
(n=197)\end{array}$} & $\mathrm{Pb}$ & $S$ & $\mathrm{Zn}$ & $\mathbf{F e}$ & $\mathrm{Cd}$ & Ag & As & $\mathrm{Cu}$ & Co & $\mathrm{Sb}$ & $\mathrm{Ni}$ & $\mathrm{Au}$ & Se & $\mathrm{Te}$ & $\mathbf{B i}$ & $\mathrm{Hg}$ & $\mathrm{Cl}$ & $\mathrm{Ca}$ & Mg & $\mathrm{Si}$ & Total \\
\hline & $\mathrm{wt} \%$ & $\mathrm{wt}^{\mathrm{t}} \%$ & wt $\%$ & $\mathrm{wt}^{\mathrm{t}} \%$ & ppm & ppm & ppm & ppm & ppm & ppm & ppm & ppm & ppm & ppm & ppm & ppm & ppm & ppm & ppm & ppm & wt. $\%$ \\
\hline Mean & 85.56 & 13.38 & 0.09 & 0.05 & & & 217 & 514 & 363 & 1132 & & & & & & 274 & 797 & & & & 99.53 \\
\hline S.D. & 0.53 & 0.14 & 0.09 & 0.11 & & & 540 & 388 & 276 & 2693 & & & & & & 487 & 519 & & & & 0.47 \\
\hline Min. & 82.90 & 12.86 & b.d.l. & b.d.l. & b.d.l. & b.d.l. & b.d.l. & b.d.l. & b.d.l. & b.d.l. & b.d.l. & b.d.l. & b.d.l. & b.d.l. & b.d.l. & b.d.l. & 270 & b.d.l. & b.d.l. & b.d.l. & 98.06 \\
\hline Max. & 86.81 & 14.04 & 0.84 & 1.24 & 820 & 730 & 4.370 & 1710 & 1090 & 18170 & 1280 & 1760 & 680 & 790 & & 2110 & 6560 & 3880 & 610 & 970 & 100.80 \\
\hline \multirow{2}{*}{$\begin{array}{l}\text { Pyrite/marcasite ** } \\
\qquad(n=98)\end{array}$} & $\mathrm{Fe}$ & $\mathrm{S}$ & $\mathrm{Zn}$ & $\mathrm{Pb}$ & As & Co & $\mathrm{Ni}$ & $\mathrm{Cu}$ & $\mathrm{Sb}$ & $\mathrm{Cd}$ & Ag & $\mathbf{A u}$ & Se & $\mathrm{Te}$ & $\mathrm{Bi}$ & $\mathrm{Hg}$ & $\mathrm{Cl}$ & $\mathrm{Ca}$ & Mg & $\mathrm{Si}$ & Total \\
\hline & $\mathrm{wt} \%$ & $\mathrm{wt} \%$ & $\mathrm{wt} \%$ & $\mathrm{wt}^{\mathrm{t}} \%$ & ppm & ppm & ppm & ppm & ppm & ppm & ppm & ppm & ppm & ppm & ppm & ppm & ppm & ppm & ppm & ppm & wt. $\%$ \\
\hline Mean & 45.77 & 53.12 & 0.1 & 0.08 & 2237 & 759 & 599 & 316 & & & & & & & & & & 418 & 283 & 190 & 99.68 \\
\hline S.D. & 0.68 & 0.65 & 0.17 & 0.24 & 4721 & 317 & 1909 & 309 & & & & & & & & & & 796 & 389 & 174 & 0.43 \\
\hline Min. & 43.58 & 50.73 & b.d.l. & b.d.l. & b.d.l. & b.d.l. & b.d.l. & b.d.l. & b.d.l. & b.d.l. & b.d.l. & b.d.l. & b.d.l. & b.d.l. & b.d.l. & b.d.l. & b.d.l. & b.d.l. & b.d.l. & b.d.l. & 98.50 \\
\hline Max. & 47.32 & 54.64 & 1.38 & 1.68 & 26950 & 1700 & 15230 & 1340 & 1850 & 740 & 1450 & 1380 & 830 & 340 & & 600 & 2110 & 4680 & 1800 & 1280 & 100.71 \\
\hline $\begin{array}{l}\text { Note: Mean-Ar } \\
\text { contents of: Mo } \\
\text { Sphalerite sampl } \\
\text { 02; TN-314/01; T1 } \\
\text { TN-297/03; TN-3 } \\
\text { TN-318/02; Z-9/0 }\end{array}$ & metic & 1. & $-\mathrm{s}$ & ard & atior & Min.- & $\lim$ & cont & ts; M & $-\mathrm{ma}$ & hum & ent & Sn, & $\#$. & ure & ere & w de & $97 /$ & $\left({ }^{*} \mathrm{~b}\right.$ & ). $\mathrm{M}$ & $\begin{array}{l}\text { num } \\
\text { e. }{ }^{* *} \\
05 / 0 \text {, } \\
3 / 02 ; \\
4 / 02 ;\end{array}$ \\
\hline
\end{tabular}


Table 5. Average EPMA analyses of different types of sphalerites from the main ore stage in the Zn-Pb (MVT) deposits in Poland.

\begin{tabular}{|c|c|c|c|c|c|c|c|c|c|c|c|c|c|c|c|c|c|c|c|c|c|}
\hline Sphalerite & $\mathrm{Zn}$ & $\mathrm{S}$ & $\mathrm{Fe}$ & $\mathrm{Pb}$ & $\mathrm{Cd}$ & Ag & $\mathrm{Sb}$ & $\mathrm{Cl}$ & $\mathrm{Bi}$ & Se & As & $\mathrm{Cu}$ & $\mathbf{N i}$ & Co & Mn & $\mathrm{Hg}$ & $\mathbf{A u}$ & $\mathrm{Mg}$ & $\mathrm{Ca}$ & Si & Total \\
\hline $\begin{array}{l}\text { Collomorphic ** } \\
\quad(n=84)\end{array}$ & $\mathrm{wt} \%$ & $\mathrm{wt} \%$ & ppm & ppm & ppm & ppm & ppm & ppm & ppm & ppm & ppm & ppm & $\mathrm{ppm}$ & ppm & ppm & ppm & ppm & ppm & ppm & ppm & wt $\%$ \\
\hline Mean & 65.76 & 32.54 & 4322 & 1482 & 1033 & & & 3213 & & & & & & & & & & & & & 99.52 \\
\hline S.D. & 0.58 & 0.46 & 4110 & 1289 & 1317 & & & 1530 & & & & & & & & & & & & & 0.49 \\
\hline Min. & 63.49 & 31.06 & * b.d.l. & b.d.l. & b.d.l. & b.d.l. & b.d.l. & 560 & b.d.l. & b.d.l. & b.d.l. & b.d.l. & b.d.l. & b.d.l. & b.d.l. & b.d.l. & b.d.l. & b.d.l. & b.d.l. & b.d.l. & 98.27 \\
\hline Max. & 67.00 & 33.39 & 22,050 & 6780 & 5830 & 720 & & 6520 & & 1620 & 3070 & 1310 & 910 & 710 & & & 1020 & 720 & & 690 & 100.38 \\
\hline $\begin{array}{c}\text { Sphalerite } \\
\text { Breccia }(n=9)\end{array}$ & $\begin{array}{c}\mathbf{Z n} \\
\mathrm{wt} \%\end{array}$ & $\begin{array}{c}\mathbf{S} \\
\mathrm{wt} \%\end{array}$ & $\begin{array}{l}\mathrm{Pb} \\
\mathrm{ppm}\end{array}$ & $\begin{array}{l}\text { Fe } \\
\text { ppm }\end{array}$ & $\begin{array}{l}\text { Cd } \\
\text { ppm }\end{array}$ & $\begin{array}{l}\mathrm{Ag} \\
\mathrm{ppm}\end{array}$ & $\begin{array}{l}\mathrm{Sb} \\
\mathrm{ppm}\end{array}$ & $\begin{array}{c}\mathrm{Cl} \\
\mathrm{ppm}\end{array}$ & $\begin{array}{c}\text { Bi } \\
\text { ppm }\end{array}$ & $\begin{array}{l}\text { Se } \\
\text { ppm }\end{array}$ & $\begin{array}{l}\text { As } \\
\text { ppm }\end{array}$ & $\begin{array}{l}\mathrm{Cu} \\
\mathrm{ppm}\end{array}$ & $\begin{array}{c}\mathbf{N i} \\
\text { ppm }\end{array}$ & $\begin{array}{l}\text { Co } \\
\text { ppm }\end{array}$ & $\begin{array}{l}\text { Mn } \\
\text { ppm }\end{array}$ & $\begin{array}{l}\mathrm{Hg} \\
\mathrm{ppm}\end{array}$ & $\begin{array}{l}\mathrm{Au} \\
\mathrm{ppm}\end{array}$ & $\begin{array}{l}\mathrm{Mg} \\
\mathrm{ppm}\end{array}$ & $\begin{array}{l}\text { Ca } \\
\text { ppm }\end{array}$ & $\begin{array}{c}\mathrm{Si} \\
\mathrm{ppm}\end{array}$ & $\begin{array}{l}\text { Total } \\
w t \%\end{array}$ \\
\hline Mean & 65.62 & 32.28 & 3790 & & 5741 & & & 2306 & & & & 228 & 220 & 182 & 307 & & & & & & 98.97 \\
\hline S.D. & 0.43 & 0.56 & 550 & & 1880 & & & 1475 & & & & 199 & 156 & 169 & 152 & & & & & & 0.78 \\
\hline Min. & 65.06 & 31.35 & b.d.l. & b.d.l. & 2750 & b.d.l. & b.d.l. & 240 & b.d.l. & b.d.l. & b.d.l. & b.d.l. & b.d.l. & b.d.l. & b.d.l. & b.d.l. & b.d.l. & b.d.l. & b.d.l. & b.d.l. & 97.95 \\
\hline Max. & 66.24 & 32.94 & 1300 & 530 & 8620 & 1510 & & 4330 & & & & 570 & 530 & 470 & 550 & & & 350 & 160 & 290 & 100.29 \\
\hline $\begin{array}{c}\text { Sphalerite } \\
\text { Granular }(n=253)\end{array}$ & $\begin{array}{c}\mathbf{Z n} \\
\mathrm{wt} \%\end{array}$ & $\begin{array}{c}\mathbf{S} \\
\mathrm{wt} \%\end{array}$ & $\begin{array}{l}\mathbf{P b} \\
\mathrm{ppm}\end{array}$ & $\begin{array}{l}\text { Fe } \\
\text { ppm }\end{array}$ & $\begin{array}{l}\mathrm{Cd} \\
\mathrm{ppm}\end{array}$ & $\begin{array}{c}\text { Ag } \\
\text { ppm }\end{array}$ & $\begin{array}{l}\mathrm{Sb} \\
\mathrm{ppm}\end{array}$ & $\begin{array}{c}\mathrm{Cl} \\
\mathrm{ppm}\end{array}$ & $\begin{array}{c}\mathbf{B i} \\
\mathrm{ppm}\end{array}$ & $\begin{array}{l}\text { Se } \\
\text { ppm }\end{array}$ & $\begin{array}{l}\text { As } \\
\mathrm{ppm}\end{array}$ & $\begin{array}{l}\mathrm{Cu} \\
\mathrm{ppm}\end{array}$ & $\begin{array}{c}\mathbf{N i} \\
\text { ppm }\end{array}$ & $\begin{array}{l}\text { Co } \\
\text { ppm }\end{array}$ & $\begin{array}{l}\text { Mn } \\
\text { ppm }\end{array}$ & $\begin{array}{l}\mathrm{Hg} \\
\mathrm{ppm}\end{array}$ & $\begin{array}{l}\mathrm{Au} \\
\mathrm{ppm}\end{array}$ & $\begin{array}{l}\mathrm{Mg} \\
\mathrm{ppm}\end{array}$ & $\begin{array}{l}\mathrm{Ca} \\
\mathrm{ppm}\end{array}$ & $\begin{array}{l}\text { Si } \\
\text { ppm }\end{array}$ & $\begin{array}{l}\text { Total } \\
\text { wt } \%\end{array}$ \\
\hline Mean & 65.96 & 32.54 & 444 & 2708 & 4242 & & & 1089 & & & & 477 & 204 & 199 & 222 & & & 300 & 423 & 181 & 99.63 \\
\hline S.D. & 0.72 & 0.43 & 1049 & 5123 & 4530 & & & 1396 & & & & 830 & 189 & 195 & 207 & & & 540 & 689 & 149 & 0.66 \\
\hline Min. & 62.96 & 30.27 & b.d.l. & b.d.l. & b.d.l. & b.d.l. & b.d.l. & b.d.l. & b.d.l. & b.d.l. & b.d.l. & b.d.l. & b.d.l. & b.d.l. & b.d.l. & b.d.l. & b.d.l. & b.d.l. & b.d.l. & b.d.l. & 94.14 \\
\hline Max. & 67.69 & 33.60 & 12,410 & 24,830 & 26,390 & 3310 & 10,040 & 8430 & 580 & 800 & 5250 & 10,470 & 850 & 810 & 700 & 1250 & 1330 & 5800 & 4590 & 1380 & 100.99 \\
\hline
\end{tabular}

Note: Mean—Arithmetic mean; S.D.—-standard deviation; Min.—-minimum contents; Max.—-maximum contents; Sc, Sn, and In measured were below detection limit (* b.d.l.). Maximum contents of: Mo 760 ppm in sphalerite; Al 0.124 wt\% in granular sphalerite. ${ }^{* *}$ Sphalerite collomorphic sample numbers from active mine (in bold): KL-6/05, POM-1/03, POM-2/0; Sphalerite breccia sample numbers from borehole TN-323/01; Sphalerite granular sample numbers from borehole or active mine (in bold): 13KM/01, TN-335/01, Z-9/04, TN-314/02, Z-9/02, 2G/02, 7G/01, OLK-1/01, OLK-2/03A, TN-205/2, Za-20/01, POM-1/03, POM-2/01, OLK-2/03A, TN-205/1. 

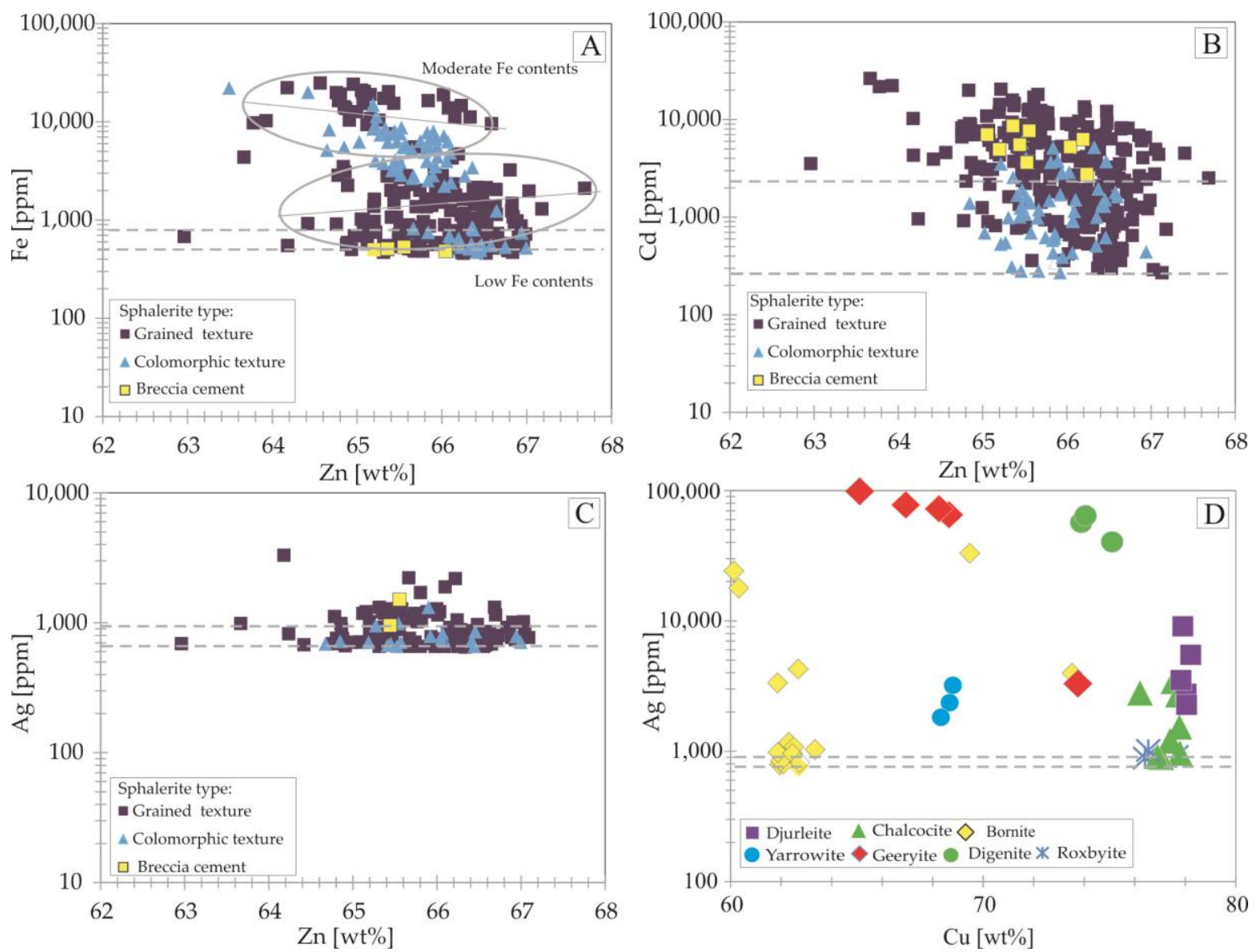

Figure 15. Bivariate trace element plots based on EPMA for sulfides minerals from $\mathrm{Zn}-\mathrm{Pb}(\mathrm{A}-\mathrm{C})$ and $\mathrm{Cu}-\mathrm{Ag}(\mathbf{D})$ deposits, 0 values and values below low precision limits are not presented on the logarithmic axis. Note: horizontal grey dashed lines indicate the range of precision of measurements in the entire population for a given element. (A) Zn vs. Fe in sphalerite, (B) Zn vs. Cd in sphalerite, (C) Zn vs. Ag in sphalerite, and (D) Cu vs. Ag in Cu sulfides.

Pyrite and marcasite together with galena and sphalerite are part of typical paragenesis for the $\mathrm{Zn}-\mathrm{Pb}$ ores in the ore-bearing dolomite (Figure 14A-D). They usually form granular aggregates. Pyrite typically occurs as cubes, whereas marcasite more often creates disintegrated earthy masses. Marcasite co-exists and encrusts sphalerite and galena of collomorphic forms (Figures 4B and 14B,C). Because pyrite and marcasite are polymorphs of the $\mathrm{FeS}_{2}$ and they are indistinguishable in the analysis of chemical composition in the microprobe studies, the results of these examinations were presented together. Fe content averages $45.77 \mathrm{wt} \%$ (s.d. $=0.68 \mathrm{wt} \%$ and $n=98$ ), and average $\mathrm{S}$ is $53.12 \mathrm{wt} \%$ (s.d. $=0.65 \mathrm{wt} \%$ and $n=98$ ) (Table 4 ), 0 to $2.69 \mathrm{wt} \%$ As, 0 to $1.38 \mathrm{wt} \% \mathrm{Zn}$, up to $1340 \mathrm{ppm} \mathrm{Cu}$, and in one measurement up to $1380 \mathrm{ppm} \mathrm{Au}$, and up to $1090 \mathrm{ppm}$ Mo. The content of Ni usually does not exceed $3000 \mathrm{ppm}$, only in one sample the value of Ni reaches $1.52 \mathrm{wt} \%$. Cobalt and $\mathrm{Sb}$ concentrations are up to $1700 \mathrm{ppm}$ and $1850 \mathrm{ppm}$, respectively.

Cerussite $\left(\mathrm{PbCO}_{3}\right)$ is a typical mineral of lead oxidation or low-temperature hydrothermal activity. It is found sporadically in the studied rocks in the form of small but macroscopically visible yellow crystals in the vicinity of other ore minerals (galena, sphalerite, and pyrite). It contains about 74 to $76 \mathrm{wt} \% \mathrm{~Pb}$ and trace element concentration up to $0.67 \mathrm{wt} \% \mathrm{Ca}$, up to $1.2 \mathrm{wt} \% \mathrm{Zn}$, and up to $0.11 \mathrm{wt} \%$ $\mathrm{Cu}$. Increased calcium content in cerussite correlates with increased $\mathrm{Zn}$ content. Willemite $\left(\mathrm{Zn}_{2} \mathrm{SiO}_{4}\right)$ has also been identified, which is a typical mineral of the oxidation zone for $\mathrm{Zn}$ and $\mathrm{Pb}$ ore deposits [37]. It occurs as lath-shaped or rosette-like crystals. Willemite contains $12 \mathrm{wt} \% \mathrm{Si}, 28$ to $29 \mathrm{wt} \% \mathrm{O}$, and 58 
to $59 \mathrm{wt} \% \mathrm{Zn}$. In addition to small amounts of Fe, up to $3600 \mathrm{ppm}$, it does not show significant concentrations of other elements.

\subsection{Cu-Ag Stratiform Deposit on the Fore-Sudetic Monocline}

\subsubsection{Results of Bulk-Rock Geochemical Investigation}

The samples $(n=62)$ come from archival boreholes located in the Lubin-Małomice, Polkowice, Radwanice-Gaworzyce, Rudna, and Sieroszowice deposits, and individual samples $(n=9)$ from the active mines of Rudna, Polkowice, and Lubin (Figure 10B). Specimens of both reduced and oxidized rocks were investigated. Reduced profiles of the Zechstein $\mathrm{Cu}$-bearing series above the oxidized rocks are characterized by significant variability of metals and composition of sulfide minerals. The main commodities are $\mathrm{Cu}$ and Ag. The bulk-rock geochemical investigation of the examined reduced ore-bearing samples revealed $\mathrm{Cu}$ content in the range from $113 \mathrm{ppm}$ to approximately $18.25 \%$ (Table 6). Arithmetic mean for copper is $4.8 \%(n=71$ and s.d. $=4.7 \%)$. About $25 \%$ of the total sample population has $<1 \% \mathrm{Cu}$ (Figure 16A). Concentrations of $\mathrm{Cu}>2.7 \%$, on the other hand, show more than $50 \%$ of all samples. Copper has a weak correlation with $\mathrm{Mo}(\mathrm{r}=0.68$, Table 7 and Figure $16 \mathrm{~A}), \mathrm{V}(\mathrm{r}=0.63)$, and $\mathrm{Ag}$ $(\mathrm{r}=0.62$, Figure 16B) and slightly weaker with Re (Figure 16C) and $\mathrm{Ni}(\mathrm{r}=0.55), \mathrm{Tl}(\mathrm{r}=0.49)$, and Se $(\mathrm{r}=0.48)$ or $\mathrm{Bi}(\mathrm{r}=0.41)$. The average arithmetic content of Ag amounts to approximately $68 \mathrm{ppm}$ (s.d. $=79.3 \mathrm{ppm}$ ) and can vary from 1.1 to $377 \mathrm{ppm}$ (Table 6 and Figure 16B). Most often, the samples contain $\mathrm{Ag}$ in the range of up to $10 \mathrm{ppm}(n=33)$ and between 10 and $20 \mathrm{ppm}(n=23)$.
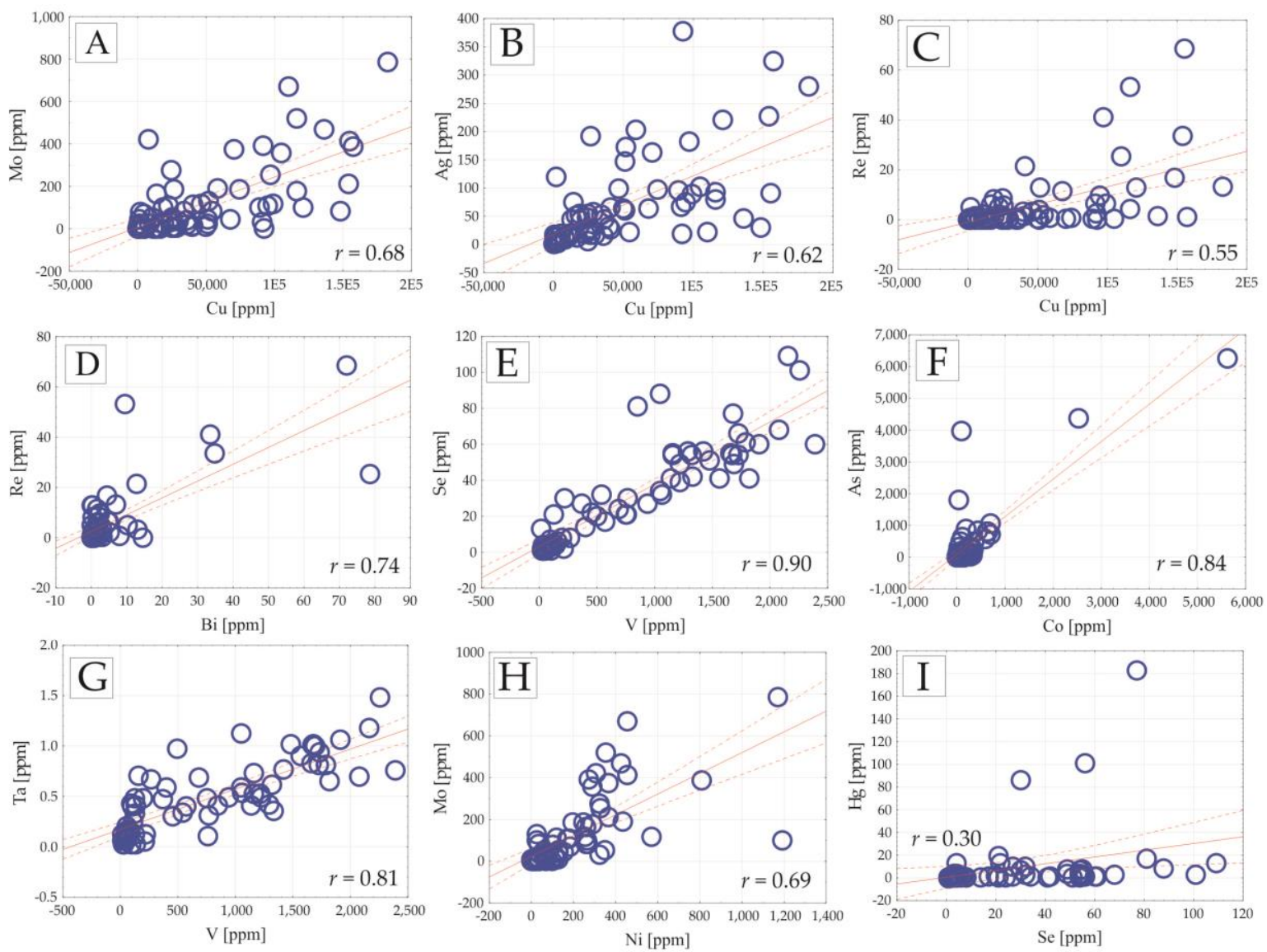

Figure 16. Scatter plots with marked trend line of bulk-rock analyses of $\mathrm{Cu}-\mathrm{Ag}$ sulfide ores from the Kupferschiefer deposits on the Fore-Sudetic Monocline in Poland: (A) Cu vs. Mo, (B) Cu vs. Ag, (C) Cu vs. Re, (D) Bi vs. Re, (E) V vs. Se, (F) Co vs. As, (G) V vs. Ta, (H) Ni vs. Mo, and (I) Se vs. Hg. Note: $95 \%$ confidence intervals are shown as the red dotted lines, while the line of best fit is shown as the red line. 
Table 6. Basic statistical parameters for main commodities ( $\mathrm{Cu}$ and $\mathrm{Ag}$ ) and associated trace elements (in ppm) in the bulk-rock samples of $\mathrm{Cu}$-Ag ores from the Kupferschiefer deposits on the Fore-Sudetic Monocline in Poland.

\begin{tabular}{|c|c|c|c|c|c|c|c|}
\hline Element & $\begin{array}{l}\text { Number of } \\
\text { Samples }\end{array}$ & $\begin{array}{l}\text { Arithmetic } \\
\text { Mean }\end{array}$ & $\begin{array}{c}\text { Geometric } \\
\text { Mean }\end{array}$ & Median & $\begin{array}{c}\text { Minimum } \\
\text { Content }\end{array}$ & $\begin{array}{c}\text { Maximum } \\
\text { Content }\end{array}$ & $\begin{array}{c}\text { Standard } \\
\text { Deviation }\end{array}$ \\
\hline Ag & 71 & 67.9 & 33.1 & 43.9 & 1.1 & 377 & 79.3 \\
\hline As & 71 & 381.3 & 38.1 & 30 & $<2$ & 6250 & 1022.3 \\
\hline $\mathbf{A u}$ & 71 & 0.247 & 0.003 & 0.002 & $<0.001$ & 0.778 & 1.156 \\
\hline $\mathbf{B i}$ & 71 & 5 & 0.8 & 0.5 & $<0.05$ & 78.7 & 13.6 \\
\hline $\mathrm{Cd}$ & 71 & 5.0 & 0.8 & 0.6 & $<0.1$ & 71.3 & 11.7 \\
\hline Co & 71 & 243.3 & 53.7 & 61.7 & $<3$ & 5630 & 729.1 \\
\hline $\mathrm{Cu}$ & 71 & $47,974.5$ & $19,385.2$ & 28,500 & 113 & 182,464 & $47,904.4$ \\
\hline Hf & 71 & 1.7 & 1.5 & 1.8 & 0.37 & 4 & 0.8 \\
\hline $\mathrm{Hg}$ & 62 & 9 & 1.7 & 1.3 & 0.1 & 183 & 27.9 \\
\hline In & 71 & 0.06 & 0.045 & 0.05 & $<0.05$ & 0.29 & 0.047 \\
\hline Mn & 71 & 1830.2 & 1456.3 & 1660 & 152 & 6784.6 & 1166.4 \\
\hline Mo & 71 & 120.3 & 39.1 & 44.5 & 1.6 & 784.9 & 167.6 \\
\hline $\mathrm{Nb}$ & 71 & 92.8 & 1.6 & 1.2 & $<0.5$ & 3,210 & 529.4 \\
\hline $\mathrm{Ni}$ & 71 & 194.1 & 92.2 & 117 & $<3$ & 1,190 & 233 \\
\hline $\operatorname{Re}$ & 71 & 5.8 & 0.9 & 0.9 & $<0.05$ & 68.7 & 12.3 \\
\hline $\mathrm{Sb}$ & 71 & 91.7 & 1.3 & 1.1 & $<0.05$ & 3,210 & 529.6 \\
\hline Sc & 71 & 9.5 & 8.1 & 10.8 & 0.7 & 20.1 & 4.3 \\
\hline Se & 71 & 28.8 & 13.4 & 21 & $<2$ & 109 & 27.7 \\
\hline Sn & 71 & 3.8 & 3.5 & 4 & 1 & 8 & 1.4 \\
\hline Ta & 71 & 0.5 & 0.3 & 0.4 & $<0.05$ & 1.5 & 0.4 \\
\hline Th & 71 & 6.5 & 5.5 & 7.4 & $<3$ & 14.5 & 3.2 \\
\hline $\mathrm{Tl}$ & 71 & 2.2 & 1.7 & 1.8 & 0.26 & 7.3 & 1.7 \\
\hline $\mathbf{V}$ & 71 & 740.2 & 328.7 & 497 & 15 & 2393 & 716.9 \\
\hline W & 71 & 1.2 & 1 & 1.3 & 0.2 & 4.9 & 0.8 \\
\hline $\mathbf{Y}$ & 71 & 18 & 15.8 & 16.2 & 4 & 50.3 & 9.5 \\
\hline La & 71 & 21.4 & 19.3 & 23.2 & 5.7 & 44.3 & 8.76 \\
\hline $\mathrm{Ce}$ & 71 & 42.7 & 38.5 & 43.6 & 10.4 & 95.7 & 17.7 \\
\hline Pr & 71 & 5.8 & 5.1 & 5.3 & 1.4 & 15.5 & 2.8 \\
\hline Nd & 71 & 23.9 & 20.9 & 21.6 & 5.2 & 70.9 & 12.6 \\
\hline $\mathbf{E u}$ & 71 & 1.2 & 1 & 0.9 & 0.28 & 3.8 & 0.7 \\
\hline Sm & 71 & 5.4 & 4.7 & 4.5 & 1.16 & 17.9 & 3.2 \\
\hline Gd & 71 & 4.6 & 3.9 & 4 & 0.92 & 14.6 & 2.7 \\
\hline $\mathrm{Tb}$ & 71 & 0.6 & 0.5 & 0.5 & 0.13 & 2 & 0.4 \\
\hline Dy & 71 & 3.5 & 3.1 & 2.9 & 0.72 & 10.3 & 1.9 \\
\hline Ho & 71 & 0.6 & 0.6 & 0.6 & 0.16 & 1.8 & 0.3 \\
\hline $\mathrm{Er}$ & 71 & 1.7 & 1.6 & 1.6 & 0.41 & 4.6 & 0.8 \\
\hline $\mathrm{Tm}$ & 71 & 0.2 & 0.2 & 0.2 & 0.06 & 0.6 & 0.1 \\
\hline $\mathrm{Yb}$ & 71 & 1.5 & 1.3 & 1.4 & 0.44 & 3.3 & 0.6 \\
\hline $\mathbf{L u}$ & 71 & 0.2 & 0.2 & 0.2 & 0.06 & 0.5 & 0.1 \\
\hline Element & $\begin{array}{c}\text { Number of Sample } \\
\text { below/above } \\
\text { Detection Limit }\end{array}$ & $\begin{array}{l}\text { Arithmetic } \\
\text { Mean }\end{array}$ & $\begin{array}{l}\text { Geometric } \\
\text { Mean }\end{array}$ & Median & $\begin{array}{c}\text { Minimum } \\
\text { Content }\end{array}$ & $\begin{array}{c}\text { Maximum } \\
\text { Content }\end{array}$ & $\begin{array}{l}\text { Standard } \\
\text { Deviation }\end{array}$ \\
\hline In & $35 / 36$ & $/ 0.09$ & $/ 0.08$ & $/ 0.07$ & $<0.05 / 0.05$ & $<0.05 / 0.3$ & $/ 0.1$ \\
\hline Pd & $61 / 10$ & & & & $<0.005 / 0.005$ & $<0.005 / 0.153$ & \\
\hline Pt & $59 / 12$ & & & & $<0.01 / 0.01$ & $<0.01 / 0.184$ & \\
\hline
\end{tabular}

Note: Measured Te contents in the all samples $(n=71)$ were below detection limit $(<0.5 \mathrm{ppm})$ by ICP-MS. 
Table 7. Pearson's correlation coefficients of selected elements for the bulk-rock analyses of Cu-Ag ores from the Kupferschiefer deposits in Poland.

\begin{tabular}{|c|c|c|c|c|c|c|c|c|c|c|c|c|c|c|c|c|c|c|c|c|c|c|c|c|}
\hline Eleme-nt & Ag & As & $\mathrm{Au}$ & $\mathbf{B i}$ & Co & $\mathrm{Cu}$ & Hf & $\mathrm{Hg}$ & In & Mn & Mo & $\mathrm{Nb}$ & $\mathrm{Ni}$ & $\operatorname{Re}$ & $\mathrm{Sb}$ & Sc & Se & Sn & Ta & Th & Tl & V & W & $\mathbf{Y}$ \\
\hline As & -0.01 & & & & & & & & & & & & & & & & & & & & & & & \\
\hline $\mathrm{Au}$ & -0.16 & -0.06 & & & & & & & & & & & & & & & & & & & & & & \\
\hline $\mathbf{B i}$ & 0.08 & 0.13 & -0.02 & & & & & & & & & & & & & & & & & & & & & \\
\hline Co & 0.05 & 0.84 & -0.06 & 0.12 & & & & & & & & & & & & & & & & & & & & \\
\hline $\mathrm{Cu}$ & 0.62 & -0.08 & -0.21 & 0.41 & 0.03 & & & & & & & & & & & & & & & & & & & \\
\hline Hf & 0.05 & -0.07 & -0.21 & 0.14 & 0.07 & 0.29 & & & & & & & & & & & & & & & & & & \\
\hline $\mathrm{Hg}$ & -0.07 & -0.04 & 0.25 & -0.01 & -0.05 & 0.27 & 0.10 & & & & & & & & & & & & & & & & & \\
\hline In & -0.21 & 0.18 & -0.08 & -0.05 & -0.08 & -0.12 & -0.33 & -0.06 & & & & & & & & & & & & & & & & \\
\hline Mn & 0.10 & 0.08 & 0.11 & -0.08 & -0.05 & -0.12 & -0.37 & 0.05 & 0.11 & & & & & & & & & & & & & & & \\
\hline Mo & 0.36 & 0.06 & -0.12 & 0.46 & 0.14 & 0.68 & 0.29 & -0.05 & 0.18 & -0.21 & & & & & & & & & & & & & & \\
\hline $\mathrm{Nb}$ & -0.11 & 0.42 & -0.04 & 0.09 & -0.04 & -0.12 & -0.14 & 0.04 & 0.45 & 0.22 & -0.05 & & & & & & & & & & & & & \\
\hline $\mathrm{Ni}$ & 0.40 & 0.49 & -0.11 & 0.26 & 0.64 & 0.55 & 0.37 & 0.06 & -0.03 & -0.23 & 0.69 & -0.06 & & & & & & & & & & & & \\
\hline $\operatorname{Re}$ & 0.23 & 0.06 & -0.09 & 0.74 & 0.11 & 0.55 & 0.22 & 0.06 & -0.15 & -0.17 & 0.36 & -0.05 & 0.29 & & & & & & & & & & & \\
\hline $\mathrm{Sb}$ & -0.12 & 0.42 & -0.04 & 0.09 & -0.04 & -0.12 & -0.14 & 0.04 & 0.45 & 0.22 & -0.05 & 0.99 & -0.06 & -0.05 & & & & & & & & & & \\
\hline Sc & -0.04 & -0.07 & -0.21 & 0.19 & 0.04 & 0.23 & 0.89 & 0.03 & -0.25 & -0.18 & 0.33 & -0.09 & 0.32 & 0.23 & -0.09 & & & & & & & & & \\
\hline Se & 0.11 & -0.12 & -0.08 & 0.27 & -0.02 & 0.48 & 0.67 & 0.30 & -0.13 & -0.14 & 0.45 & -0.10 & 0.43 & 0.38 & -0.10 & 0.68 & & & & & & & & \\
\hline Sn & 0.01 & -0.13 & -0.27 & 0.12 & -0.01 & 0.22 & 0.71 & -0.03 & -0.22 & -0.28 & 0.30 & -0.10 & 0.29 & 0.17 & -0.10 & 0.77 & 0.51 & & & & & & & \\
\hline Ta & 0.13 & 0.01 & -0.20 & 0.28 & 0.18 & 0.40 & 0.86 & 0.12 & -0.30 & -0.30 & 0.45 & -0.16 & 0.50 & 0.35 & -0.16 & 0.88 & 0.76 & 0.72 & & & & & & \\
\hline Th & 0.03 & -0.07 & -0.25 & 0.14 & 0.04 & 0.23 & 0.96 & 0.03 & -0.30 & -0.26 & 0.28 & -0.06 & 0.33 & 0.20 & -0.06 & 0.93 & 0.60 & 0.75 & 0.85 & & & & & \\
\hline $\mathrm{Tl}$ & 0.14 & 0.04 & -0.21 & 0.14 & 0.18 & 0.49 & 0.29 & 0.19 & 0.47 & -0.12 & 0.57 & -0.18 & 0.42 & 0.16 & -0.18 & 0.28 & 0.37 & 0.27 & 0.35 & 0.25 & & & & \\
\hline V & 0.25 & -0.09 & -0.15 & 0.37 & 0.00 & 0.63 & 0.71 & 0.20 & -0.06 & -0.26 & 0.60 & -0.07 & 0.55 & 0.47 & -0.07 & 0.70 & 0.90 & 0.57 & 0.81 & 0.64 & 0.42 & & & \\
\hline W & 0.08 & 0.27 & -0.20 & 0.06 & 0.48 & 0.22 & 0.62 & 0.15 & -0.20 & -0.24 & 0.29 & -0.12 & 0.57 & 0.16 & -0.12 & 0.63 & 0.37 & 0.59 & 0.69 & 0.66 & 0.31 & 0.42 & & \\
\hline $\mathbf{Y}$ & -0.19 & -0.08 & 0.39 & 0.10 & 0.01 & -0.09 & 0.50 & 0.12 & -0.32 & 0.11 & -0.02 & -0.14 & 0.06 & 0.10 & -0.14 & 0.51 & 0.56 & 0.39 & 0.47 & 0.45 & -0.05 & 0.37 & 0.24 & \\
\hline La & -0.02 & -0.05 & -0.21 & 0.13 & 0.00 & 0.24 & 0.87 & 0.15 & -0.33 & -0.03 & 0.22 & 0.04 & 0.29 & 0.18 & 0.04 & 0.91 & 0.74 & 0.68 & 0.81 & 0.89 & 0.20 & 0.67 & 0.58 & 0.59 \\
\hline
\end{tabular}

Note: Pearson's correlation is based on 71 of the bulk-rock analyses samples (excluding Hg and In, based on 62 and 36 samples, respectively, see Table 6) with Cu-Ag ore mineralization coefficients with absolute values greater than 0.30 that are statistically significant at the $95 \%$; Value in bold indicating for correlation coefficient interpreted as follows: $\mathrm{r}=0.5$ to 0.7 weak correlation, $r=0.7$ to 0.9 strong correlation, and $r \geq 0.9$ very strong correlation. 
The main commodities are accompanied by several trace elements which include: Re, Se, Co, $\mathrm{V}, \mathrm{Ni}, \mathrm{Hg}, \mathrm{Bi}, \mathrm{REE}$, and others (Table 6). The concentration of Re in the samples is in the narrow range from $<0.05$ to $68.3 \mathrm{ppm}$ (Figure $16 \mathrm{C}, \mathrm{D})$, and the arithmetic mean is $5.8 \mathrm{ppm}$ (s.d. $=12.3 \mathrm{ppm}$ ). Rhenium shows a strong correlation with $\mathrm{Bi}(\mathrm{r}=0.74)$, and also weak correlations with $\mathrm{V}$, Mo, and Se (Table 7). Selenium is present in a large range of $<2 \mathrm{ppm}$ (six samples) to 109 ppm (Figure 16E). Most samples have contents ranging from 1 (detection limit) to 8 ppm Se $(n=29)$ and 40 samples have contents $>15$ ppm. Arithmetic mean of selenium content is $28.8 \mathrm{ppm}$ (s.d. $=27.7 \mathrm{ppm}$ ). Cobalt shows a large range of $<3 \mathrm{ppm}$ to $5630 \mathrm{ppm}$ (Figure 16F). Arithmetic mean for Co is $243.3 \mathrm{ppm}(n=71$ and s.d. $=729.1 \mathrm{ppm})$. Cobalt strongly correlates with As $(\mathrm{r}=0.84)$ and it occurs mostly in the form of cobaltite, and a weaker correlation with $\mathrm{Ni}(\mathrm{r}=0.64)$. The next trace element found in $\mathrm{Cu}-\mathrm{Ag}$ ores in elevated concentrations is $\mathrm{V}$. The arithmetic mean for $\mathrm{V}$ is $740.2 \mathrm{ppm}$ (s.d. $=716.9 \mathrm{ppm}$ ). The vanadium concentrations change largely from 15 to 2393 ppm (Figure 16G). About 38\% of all samples show concentrations $>0.1 \% \mathrm{~V}$. the population distribution is unimodal and asymmetrical. Vanadium shows a very strong correlation with Se $(r=0.90)$ and a strong correlation with Ta $(r=0.81), H f(r=0.71)$, and Sc $(r=0.70)$, a weak correlation with Th $(r=0.64), \mathrm{Cu}(r=0.63), \mathrm{Mo}(\mathrm{r}=0.60), \mathrm{Sn}(\mathrm{r}=0.57), \mathrm{Ni}$ $(\mathrm{r}=0.55)$, and very weak correlation with $\operatorname{Re}(\mathrm{r}=0.47)$ (Table 7$)$.

In addition, in $\mathrm{Cu}-\mathrm{Ag}$ sulfide ores the increased concentration of nickel (arithmetic mean $=194.1 \mathrm{ppm}$, Figure $16 \mathrm{H}$ ) is interesting as its recovery occurs in the metallurgical process of $\mathrm{Cu}$ ores in the form of Ni sulfate. Mercury occurs in slightly elevated concentrations, especially in black shale, and show a large range of content ( 0.1 to $183 \mathrm{ppm}$, Figure $16 \mathrm{I})$. The arithmetic mean $=9 \mathrm{ppm}$ $(n=62$ and s.d. $=27.9 \mathrm{ppm})$. Critical elements such as Bi (Figure 16D), Hf, In, Sb, Sc, and W are present generally in trace concentrations (Table 6). Rare earths content is low, and slight enrichments are present in the secondary oxidized rocks $[77,78]$. The highest arithmetic mean is calculated for Ce $42.7 \mathrm{ppm}(n=71$ and s.d. $=17.7 \mathrm{ppm})$, range from 10.4 to $95.7 \mathrm{ppm}$, (Table 6). The sum of LREE (La, Ce) is low and varies from 49.3 to $285.7 \mathrm{ppm}$ (arithmetic mean $=113.4 \mathrm{ppm}$ and $n=71$ ). In turn, the sum of MREE (Pr, Nd, Sm, Eu, Gd, and Tb) is between 26.1 and 140 ppm (arithmetic mean = 64.1 ppm, s.d. $=18.3 \mathrm{ppm}$, and $n=71)$ and $\operatorname{HREE}(\mathrm{Dy}, \mathrm{Er}, \mathrm{Yb}$, and $\mathrm{Lu})$ is between 108.5 and 189 ppm (arithmetic mean $=36.3 \mathrm{ppm})$. The LREE/MREE value is between 0.6 and 2.6 and LREE/HREE between 1.4 and 8.2 (arithmetic mean $=1.9 \mathrm{ppm}$ and $5.3 \mathrm{ppm}$, respectively). Figure 17A,B show concentrations of REE normalized to chondrite according to [70] and to Post Archean Australian shale (PASS) after [79]. The REE chondrite normalized graph shows a negative Eu anomaly in most samples on the PASS plot. The PASS plot exhibits the characteristic increase in MREE content relative to LREE and HREE. Yttrium content is in a narrow range between 4 and 50.3 ppm and its arithmetic mean is 18 ppm (s.d. $=9.5$ ppm).
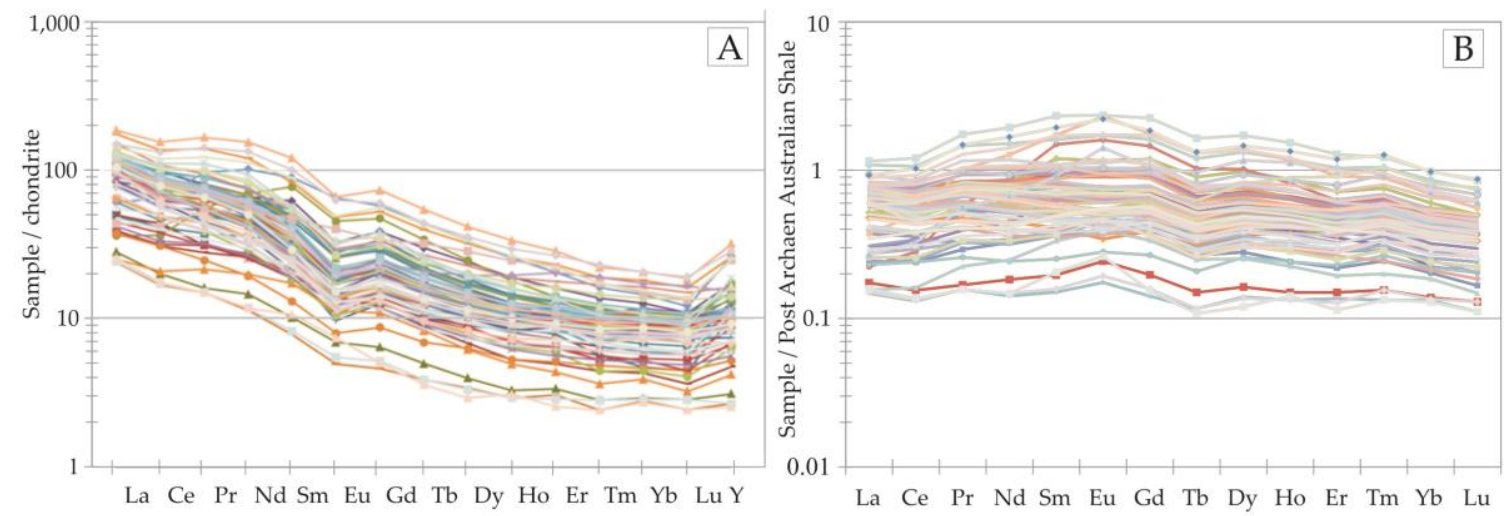

Figure 17. (A) REE diagrams normalized to chondrite, after [70] and (B) to PASS, after [79] for the Kupferschiefer $\mathrm{Cu}$-Ag deposits on the Fore-Sudetic Monocline in Poland. 


\subsubsection{Results of Mineralogical Investigation}

Ore mineralization in the Lubin-Sieroszowice Copper District is very diverse, both in terms of composition and forms of occurrence of ore minerals [52,54-59]. Mineralization is stratiform gently cross cutting the bedding and predominated by fine disseminations. The dominant are $\mathrm{Cu}$ sulfides, i.e., chalcocite, digenite, covellite, bornite, and chalcopyrite, which are accompanied by pyrite, galena, and sphalerite (Figure 18A-F). Ore minerals form hypidiomorphic and idiomorphic textures (Figure 18C). Very common are chalcocite, digenite (Figure 18G,H), bornite, and galena pseudomorphs after framboidal pyrite and pyrite framboids cemented by covellite, bornite (Tables 8 and A1, Figure 18A), sphalerite, and galena. In addition, hydrothermal metasomatic textures, open-space fillings, impregnations, replacements of carbonate cements in sandstones (Figure 18C), nest, and lenses, as well as replacements of detrital grains (Figure 18D) were recorded. Ore veinlets and stylolite with sulfides are rare. The main minerals are locally accompanied in small amounts by accessory minerals, both recognized under the microscope and the electron microprobe (Tables 8 and A1).
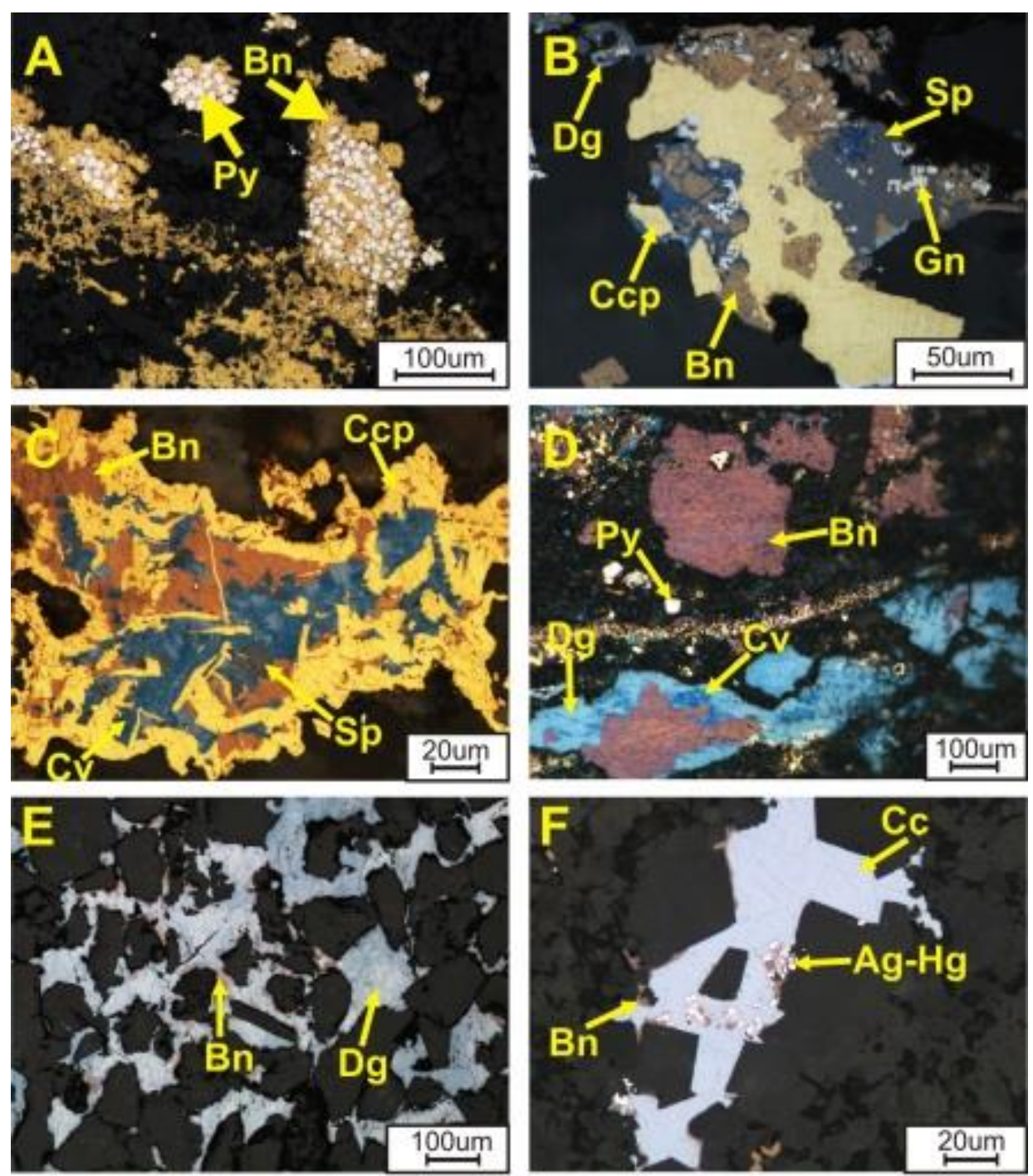

Figure 18. Cont. 

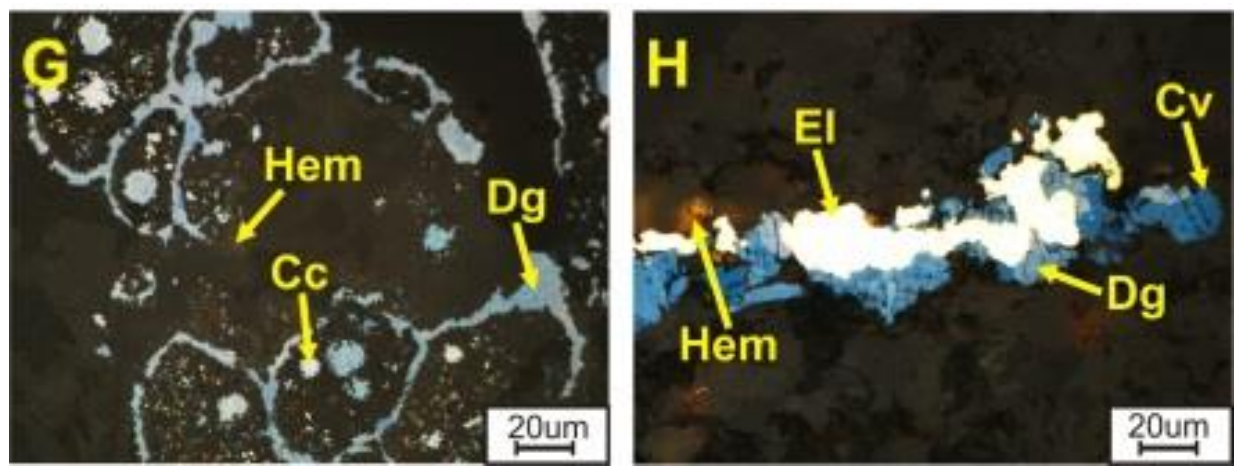

Figure 18. Photomicrographs of ore minerals from selected profiles of the Zechstein Cu-bearing series on the Fore-Sudetic Monocline in Poland (reflected light): (A) Bornite (Bn) replacing pyrite (Py) and carbonate minerals, Zechstein Limestone, S-303 borehole; (B) mineral aggregate composed of chalcopyrite (Ccp), bornite (Bn), sphalerite (Sp), galena (Gn), and digenite (Dg), Zechstein Limestone, S-209 borehole; (C) multi-mineral aggregate composed of chalcopyrite (Ccp), bornite (Bn), covellite $(\mathrm{Cv})$, and sphalerite (Sp).,Weissliegend, S-262 borehole; (D) Rich copper mineralization represented by bornite (Bn), covellite ( $\mathrm{Cv}$ ), and digenite (Dg) co-existing with pyrite (Py), Kupferschiefer, S-117 borehole; (E) detrital grains cemented by digenite (Dg) with bornite (Bn) inclusions, Weissliegend, S-196 borehole; (F) carbonate minerals partially replaced by chalcocite (Cc) with tiny inclusions of bornite (Bn) and silver alloys (Ag-Hg), Kupferschiefer, S-99 borehole; (G) digenite (Dg) replacing fragments of foram and chalcocite (Cc) inclusions accompanied by hematite pigment (Hem), Zechstein Limestone, S-389 borehole; and (H) intergrowths of electrum (El) with digenite (Dg) and covellite $(\mathrm{Cv})$ associated by hematite (Hem), Zechstein Limestone, S-391 borehole.

Table 8. Ore minerals identified in selected samples by using an electron microprobe (EPMA).

\begin{tabular}{|c|c|c|c|}
\hline Borehole & Principal Ore Mineral & Associated Minerals & Accesoric Minerals \\
\hline S-65 & digenite & roxbyite, chalcocite, djurleite, anilite, bornite, tennantite & Ag alloys \\
\hline S-87 & spionkopite & $\begin{array}{l}\text { digenite, bornite, djurleite, geerite, roxbyite, yarrowite, } \\
\text { covellite, chalcopyrite, galena, sphalerite }\end{array}$ & - \\
\hline S-99 & digenite & roxbyite, spionkopite, djurleite, anilite, bornite & - \\
\hline
\end{tabular}

Selected microprobe analyses confirmed the identification of djurleite, spionkopite, anilite, geerite, roxbyite, and yarrowite. They contain high concentrations of Ag (up to $10.1 \mathrm{wt} \%$ in geerite), Fe (up to $4.95 \mathrm{wt} \%$ ), Zn (up to $1600 \mathrm{ppm}$ ), Pb (up to $900 \mathrm{ppm}$ ), and Mo (up to $1030 \mathrm{ppm}$ ), (Table 9 and Figure 19A-F). Silver alloys commonly concentrated in mineral aggregates of $\mathrm{Cu}$ sulfides (Table 10) and contain from 39.7 to $76.7 \mathrm{wt} \% \mathrm{Ag}$ (mean $=64.2 \mathrm{wt} \%, n=24$, and s.d. $=11.7 \mathrm{wt} \%$ ) and from 19.5 to $34.4 \mathrm{wt} \% \mathrm{Hg}($ mean $=22.7 \mathrm{wt} \%$ and s.d. $=10.6 \mathrm{wt} \%)$. Noticeable are concentrations of Ag in chalcocite (up to $6.28 \mathrm{wt} \%$ ) and bornite (up to $3.29 \mathrm{wt} \%$, mean $=4024 \mathrm{ppm}, n=24$, and s.d. $=8470 \mathrm{ppm}$ ), and lower in djurleite (up to $9080 \mathrm{ppm}$ ) and yarrovite (up to $6614 \mathrm{ppm}$ ) as well as of $\mathrm{Zn}$ in anilite, roxbyite, and digenite (up to 1500 to 1600 ppm). It is very important from the point of view of technological processes to find admixtures of trace elements substituted in ore minerals, for example, $\mathrm{Fe}$ and $\mathrm{Pb}$ in sphalerite, Ag in bornite and chalcocite, Ni (up to $3147 \mathrm{ppm}$ ), and Co (up to $3.8 \mathrm{wt} \%$ ) in tennantite, Cd in sphalerite (up to $6100 \mathrm{ppm}$ ), allowing to indicate the mineral carriers of particular elements. 
Table 9. Chemical composition of Cu-S-type sulfides from the Cu-Ag Kupferschiefer deposits on the Fore-Sudetic Monocline identified by EPMA.

\begin{tabular}{|c|c|c|c|c|c|c|c|c|c|c|c|c|c|c|c|c|c|c|c|c|c|}
\hline \multirow{2}{*}{ Cu-S Type Sulfide } & \multirow{2}{*}{ Value } & $\mathrm{Cu}$ & $\mathrm{S}$ & Ag & $\mathrm{Fe}$ & Bi & $\mathrm{Cd}$ & $\mathrm{Cl}$ & Co & Mo & $\mathrm{Ni}$ & $\mathrm{Pb}$ & $\mathrm{Sb}$ & Se & Te & $\mathrm{Zn}$ & Al & $\mathrm{Ca}$ & Mg & $\mathrm{Si}$ & Total \\
\hline & & $\mathbf{w t} \%$ & $\mathbf{w t} \%$ & ppm & ppm & $\mathrm{ppm}$ & ppm & ppm & ppm & ppm & $\mathrm{ppm}$ & ppm & ppm & ppm & ppm & ppm & ppm & ppm & ppm & ppm & $\mathbf{w t} \%$ \\
\hline \multirow{4}{*}{$\begin{array}{c}\text { Chalcocite } \\
\mathrm{Cu}_{2} \mathrm{~S} \\
(n=6)\end{array}$} & mean & 75.58 & 19.76 & 45,900 & & & & & & & & & & & & 680 & & 4040 & & & 99.63 \\
\hline & s.d. & 2.55 & 1.67 & 16,700 & & & & & & & & & & & & 445 & & 4690 & & & 0.72 \\
\hline & $\min$ & 73.87 & 18.42 & 25,400 & b.d.l. & b.d.l. & b.d.l. & b.d.l. & b.d.l. & b.d.1. & b.d.l. & b.d.l. & b.d.l. & b.d.l. & b.d.l. & b.d.l. & b.d.l. & 590 & b.d.1. & b.d.l. & 99.40 \\
\hline & $\max$ & 79.33 & 19.87 & 62,800 & 450 & & & & & & 700 & & & & 320 & 1070 & 290 & 13,350 & & & 100.81 \\
\hline \multirow{4}{*}{$\begin{array}{l}\text { Djurleite } \mathrm{Cu}_{31} \mathrm{~S}_{16} \\
\qquad(\mathrm{n}=7)\end{array}$} & mean & 78.23 & 20.86 & 3331 & 880 & & & & & & & & & & & & & & & & 99.65 \\
\hline & d. & 0.29 & 0.13 & 3159 & 350 & & & & & & & & & & & & & & & & 0.08 \\
\hline & $\min$ & 77.91 & 20.68 & b.d.l. & 440 & b.d.l. & b.d.l. & b.d.l. & b.d.l. & b.d.l. & b.d.l. & b.d.l. & b.d.l. & b.d.l. & b.d.l. & b.d.l. & b.d.l. & b.d.l. & b.d.l. & b.d.l. & 99.59 \\
\hline & $\max$ & 78.79 & 21.03 & 9080 & 1460 & & & & 720 & 1030 & 1930 & 720 & & & 440 & 1320 & & & & & 99.70 \\
\hline \multirow{4}{*}{$\begin{array}{l}\text { Digenite } \\
\mathrm{Cu}_{9} \mathrm{~S}_{5} \\
(n=24)\end{array}$} & mean & 77.48 & 21.43 & 443 & 847 & & & 234 & & & & & & & & & & 580 & & & 99.53 \\
\hline & s.d. & 0.81 & 0.38 & 721 & 425 & & & 123 & & & & & & & & & & 870 & & & 0.78 \\
\hline & $\min$ & 73.76 & 19.98 & b.d.l. & b.d.l. & b.d.l. & b.d.l. & b.d.l. & b.d.l. & b.d.l. & b.d.l. & b.d.1. & b.d.l. & b.d.l. & b.d.l. & b.d.l. & b.d.l. & 120 & b.d.l. & b.d.l. & 98.7 \\
\hline & $\max$ & 78.80 & 21.84 & 3545 & 2350 & 740 & 845 & 900 & & & & 901 & 640 & & & 1580 & 5800 & 5970 & 1670 & 8970 & 100.22 \\
\hline \multirow{4}{*}{$\begin{array}{l}\text { Roxbyite } \mathrm{Cu}_{39} \mathrm{~S}_{28} \\
\quad(n=24)\end{array}$} & mean & 77.16 & 21.89 & & 792 & & & & & & & & & & & & & 650 & & & 99.52 \\
\hline & s.d. & 0.33 & 0.09 & & 720 & & & & & & & & & & & & & 1.030 & & & 0.10 \\
\hline & $\min$ & 76.39 & 21.73 & b.d.l. & b.d.l. & b.d.l. & b.d.l. & b.d.l. & b.d.l. & b.d.l. & b.d.l. & b.d.l. & b.d.l. & b.d.l. & b.d.l. & b.d.l. & b.d.l. & b.d.l. & b.d.l. & b.d.l. & 99.41 \\
\hline & $\max$ & 77.78 & 22.06 & 890 & 3140 & & 760 & 1590 & 620 & 2390 & 2.270 & & 640 & 760 & 610 & 1510 & 1440 & 4990 & & 2150 & 99.59 \\
\hline \multirow{3}{*}{$\begin{array}{l}\text { Anilite } \\
\mathrm{Cu}_{7} \mathrm{~S}_{4} \\
(\mathrm{n}=3)\end{array}$} & mean & 76.91 & 22.38 & & 545 & & & & & & & & & & & & & 745 & & & \\
\hline & s.d. & 0.11 & 0.28 & & 211 & & & & & & & & & & & & & 380 & & & \\
\hline & $\max$ & 76.94 & 22.61 & & 728 & & 500 & & & & & & & & & 1600 & 1190 & 1010 & & & \\
\hline \multirow{4}{*}{$\begin{array}{l}\text { Geerite } \\
\mathrm{Cu}_{8} \mathrm{~S}_{5}, \\
(n=5)\end{array}$} & mean & 73.80 & 24.22 & 64,900 & 3400 & & & & & & & & & & & & & & & & 99.46 \\
\hline & s.d. & 3.24 & 0.816 & 36,700 & 1700 & & & & & & & & & & & & & & & & 0.48 \\
\hline & $\min$ & 65.10 & 22.90 & 3400 & 1500 & b.d.l. & b.d.l. & b.d.l. & b.d.l. & b.d.l. & b.d.l. & b.d.l. & b.d.l. & b.d.l. & b.d.l. & b.d.l. & b.d.l. & b.d.l. & b.d.l. & b.d.l. & 99.13 \\
\hline & $\max$ & 73.80 & 24.86 & 101.000 & 5900 & & & & & & & & & & & 1400 & & & & & 100.4 \\
\hline \multirow{4}{*}{$\begin{array}{c}\text { Spionkopite } \mathrm{Cu}_{39} \mathrm{~S}_{28} \\
(n=8)\end{array}$} & mean & 72.03 & 26.96 & & 756 & & & 51 & & & & & & & & 690 & & 1143 & & 980 & 99.73 \\
\hline & s.d. & 0.60 & 0.98 & & 181 & & & 649 & & & & & & & & 750 & & 381 & & 1080 & 0.18 \\
\hline & $\min$ & 71.38 & 26.35 & b.d.l. & 550 & b.d.l. & & b.d.l. & b.d.l. & b.d.l. & b.d.l. & b.d.l. & b.d.l. & b.d.l. & b.d.l. & b.d.l. & b.d.l. & 710 & b.d.l. & 220 & 99.60 \\
\hline & $\max$ & 72.57 & 28.09 & & 890 & & & 1260 & & & & & & 720 & & 1480 & 1240 & 1430 & & 2220 & 99.98 \\
\hline \multirow{4}{*}{$\begin{array}{l}\text { Yarrowite } \\
\mathrm{Cu}_{9} \mathrm{~S}_{8} \\
(n=4)\end{array}$} & mean & 67.43 & 30.01 & 3515 & 135 & & & 1047 & & & & & & & & 740 & & & & & 99.76 \\
\hline & s.d. & 2.34 & 1.03 & 2154 & 239 & & & 1775 & & & & & & & & 401 & & & & & 0.34 \\
\hline & $\min$ & 63.94 & 28.58 & 1800 & 14000 & b.d.l. & b.d.l. & b.d.l. & b.d.l. & b.d.l. & b.d.l. & b.d.l. & b.d.l. & b.d.l. & b.d.l. & 220 & b.d.l. & b.d.l. & b.d.l. & b.d.l. & 99.34 \\
\hline & $\max$ & 68.8 & 30.81 & 6614 & 49300 & & & 3710 & & & 8940 & & & 790 & & 1190 & & & 580 & & 100.01 \\
\hline
\end{tabular}

Abbreviation: T1, Kupferschiefer; Ws, Weissliegend; b.d.l, below detection limit. Note: Au, As, and Ho contents b.d.l. n-number of determinations, mean-arithmetic mean s.d.—standard deviation, min-minimum value, max—-maximum value; Studied samples with: chalcocite (Ws/S-65/52), djurleite (T1/S-87/130, T1/S-99/86), digenite (T1/S-87/130, Ws/S-65/52, Ws/S-99/86), roxbyite (T1/S-87/130, Ws/S-65/52, T1/S-99/86, anilite (Ca1/U-106/1), geerite (T1/S-87/130), spionkopite (T1/S-87/130) and yarrowite (T1/S-87/130). 
Table 10. Chemical composition of Cu-Fe-S-type sulfides and Ag alloys from the Cu-Ag Kupferschiefer deposits on the Fore-Sudetic Monocline identified by EPMA.

\begin{tabular}{|c|c|c|c|c|c|c|c|c|c|c|c|c|c|c|c|c|c|c|c|c|c|}
\hline \multirow{2}{*}{$\begin{array}{l}\text { Cu-Fe-S-type } \\
\text { Sulfide }\end{array}$} & \multirow{2}{*}{ Value } & $\mathrm{Cu}$ & $\mathrm{Fe}$ & $S$ & $\mathrm{Ag}$ & $\mathrm{Hg}$ & As & $\mathbf{A u}$ & Cd & Co & Mo & $\mathrm{Ni}$ & $\mathrm{Sb}$ & Se & $\mathrm{Te}$ & Zn & Al & $\mathrm{Ca}$ & $\mathrm{Si}$ & $\mathrm{Cl}$ & Total \\
\hline & & $w t \%$ & $w t \%$ & $w t \%$ & ppm & ppm & ppm & ppm & ppm & ppm & ppm & ppm & ppm & ppm & ppm & ppm & ppm & ppm & ppm & ppm & $w t \%$ \\
\hline \multirow{4}{*}{$\begin{array}{c}\text { Chalcopyrite } \\
\text { CuFeS } S_{2} \\
(n=12)\end{array}$} & mean & 35.71 & 28.70 & 33.61 & & & & & & & & & & & & 1105 & & & 1.050 & & 98.47 \\
\hline & s.d. & 1.71 & 0.71 & 0.72 & & & & & & & & & & & & 510 & & & 1.096 & & 0.61 \\
\hline & $\min$ & 34.50 & 28.20 & 33.10 & b.d.l. & b.d.l. & b.d.l. & b.d.l. & b.d.l. & b.d.l. & b.d.l. & b.d.l. & b.d.l. & b.d.l. & b.d.l. & 750 & b.d.l. & b.d.l. & 970 & b.d.l. & 98.26 \\
\hline & $\max$ & 36.92 & 29.24 & 34.12 & 830 & & & & & 670 & 890 & & & 550 & & 1170 & 970 & 1440 & 1.780 & & 99.21 \\
\hline \multirow{6}{*}{$\begin{array}{c}\text { Bornite } \\
\mathrm{Cu}_{5} \mathrm{FeS} \mathrm{S}_{4} \\
(n=24)\end{array}$} & mean & 63.17 & 9.74 & 25.49 & 4024 & & & & & & & & & & & & & & 740 & & 99.25 \\
\hline & s.d. & 3.11 & 3.07 & 0.57 & 8479 & & & & & & & & & & & & & & 2699 & & 1.01 \\
\hline & $\min$ & 59.238 & 0.23 & 23.65 & b.d.l. & b.d.l. & b.d.l. & b.d.l. & b.d.l. & b.d.l. & b.d.l. & b.d.l. & b.d.l. & b.d.l. & b.d.l. & b.d.l. & b.d.l. & b.d.l. & b.d.l. & b.d.l. & 94.78 \\
\hline & $\max$ & 73.52 & 11.40 & 26.25 & 32980 & & & 910 & 720 & & 1040 & 780 & 470 & 570 & & 1460 & 9130 & 3200 & 13400 & 330 & 97.71 \\
\hline & & $\mathrm{Cu}$ & $\mathrm{Fe}$ & $S$ & $\mathrm{Ag}$ & $\mathrm{Hg}$ & As & $\mathrm{Au}$ & $\mathrm{Cd}$ & Co & Mo & $\mathrm{Ni}$ & $\mathrm{Sb}$ & Se & Te & $\mathrm{Zn}$ & Al & $\mathrm{Ca}$ & Si & $\mathrm{Cl}$ & Total \\
\hline & & $\mathrm{wt} \%$ & ppm & ppm & $w t \%$ & $w t \%$ & ppm & ppm & ppm & ppm & ppm & ppm & ppm & ppm & ppm & ppm & ppm & ppm & ppm & ppm & $\mathrm{wt} \%$ \\
\hline \multirow{4}{*}{$\begin{array}{l}\text { Ag alloys } \\
(n=24)\end{array}$} & mean & 1.58 & & 5.460 & 64.22 & 22.74 & & & & & & & & & 961 & 756 & 1972 & & 683 & 813 & 96.41 \\
\hline & s.d. & 1.37 & & 4.160 & 11.71 & 10.65 & & & & & & & & & 349 & 432 & 2279 & & 753 & 147 & 6.37 \\
\hline & $\min$ & 0.66 & b.d.l. & 690 & 39.68 & 19.56 & b.d.l. & b.d.l. & b.d.l. & b.d.l. & b.d.l. & b.d.l. & b.d.l. & b.d.l. & 700 & b.d.l. & 530 & & b.d.l. & 560 & 89.05 \\
\hline & $\max$ & 3.15 & 950 & 13.570 & 76.71 & 34.46 & 590 & & & 560 & 790 & 1120 & & & 1600 & 1450 & 7240 & & 1880 & 1060 & 101.23 \\
\hline
\end{tabular}

Abbreviation: $n$, number of determinations; mean, arithmetic mean; s.d., standard deviation; min, minimum value; max, maximum value; b.d.l., below detection limit. Studied borehole samples with chalcopyrite (T1/ S-87/130), bornite (T1/S-87/130, T1/S-65/52, T1/S-99/86) and Ag alloys (Ws/S-65/52). T1, Kupferschiefer; Ws, Weissliegend. 

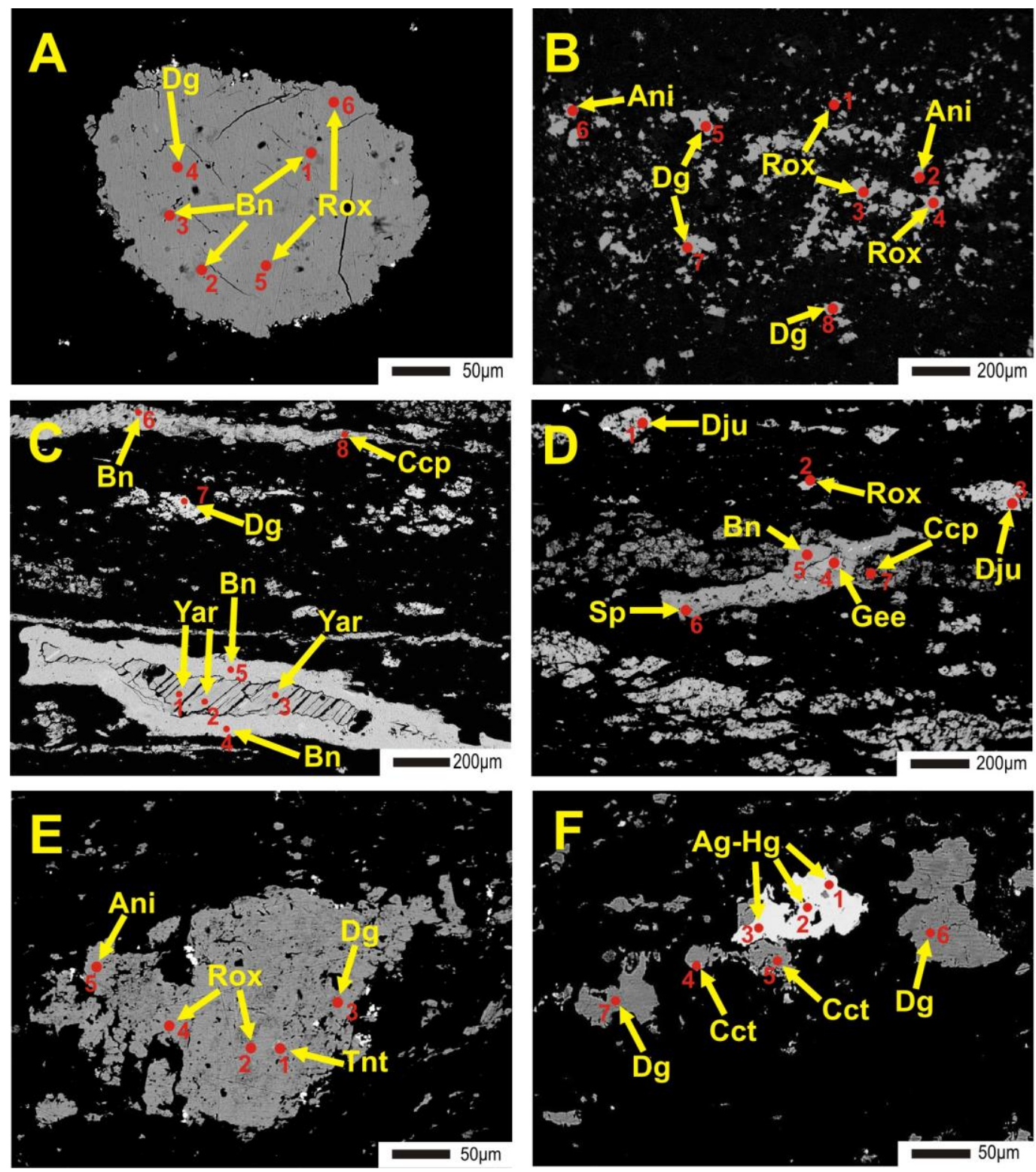

Figure 19. BSE images of ore minerals from the $\mathrm{Cu}$-Ag Kupferschiefer ores on the Fore-Sudetic Monocline: (A) Tiny inclusions of bornite (Bn) (1-3, red points) in digenite (Dg) (4) and roxbyite (Rox) (5-6) grain. Zechstein Limestone, S-99 borehole; (B) roxbyite (Rox) $(1,3,4)$, anilite (Ani) $(2,6)$, and digenite (Dg) $(5,7,8)$ scattered throughout carbonates, Zechstein Limestone, S-99 borehole; (C) rich ore mineralization represented by yarrowite (Yar) (1-3), bornite (Bn) (4-6), digenite (Dig) (7), and chalcopyrite (Ccp) (8), Kupferschiefer, S-87 borehole; (D) rich ore mineralization represented by djurleite (Dju) $(1,3)$, roxbyite (Rox) (2), geerite (Gee) (4), spionkopite (Spi) (5), bornite (Bn) (5), and sphalerite (Sp) (6) accompanied by chalcopyrite (Ccp), (7), Kupferschiefer, S-87 borehole; (E) inclusion of tennantite (Tnt) (1) in roxbyite (Rox) (2,4), digenite (Dg) (3), and anilite (Ani) (5) aggregate, Weissliegend, S-65 borehole; and (F) intergrowths of silver alloys $(\mathrm{Ag}-\mathrm{Hg})(1-3)$ with chalcocite $(\mathrm{Cct})(4,5)$ in association with digenite $(\mathrm{Dg})(6,7)$, Weissliegend, S-65 borehole.

A different type of mineralization occurs in rocks affected by secondary oxidation (Rote Fäule), occurring below reduced $\mathrm{Cu}$-ore intervals. Apart from hematite and goethite, these rocks contain relict sulfide mineralization [41,52,53,80,81], represented by scarce sulfides of Cu-S type, mainly covellite, digenite, and chalcocite, replaced partially by iron oxides (Figure 19D). Locally, increased $\mathrm{Au}$ and $\mathrm{Pt}$ concentrations were revealed in oxidized intervals, but rarely in the form of individual minerals [55,80- 
83]. Only occasionally, inclusions and intergrowths of electrum and native gold with covellite and digenite are found (Figure 18H).

\section{Discussion}

\subsection{Importance of Trace Element Distributions in Polish Sediment-Hosted Deposits as Resource for Critical Elements of the European Union}

In the 137 samples from the documented $\mathrm{Zn}-\mathrm{Pb}$ and $\mathrm{Cu}-\mathrm{Ag}$ deposits, over 40 trace elements distribution were recognized (Tables 2, 6 and 11). There were applied variable geochemical methods (ICP-MS, WD-XRF, GF AAS, and AMA 254) supported by electron microprobe investigation of trace elements composition in ore minerals. Some of these trace elements are enriched and paragenetically associated with primary metallic ores (so-called principal commodities). These trace elements are considered as the associated elements. Some of them are recovered during sulfide $\mathrm{Cu}-\mathrm{Ag}$ ore processing in Poland (Table 12), however, most of them are not recovered from either $\mathrm{Zn}-\mathrm{Pb}$ or $\mathrm{Cu}-\mathrm{Ag}$ deposits $[84,85]$. Nevertheless, several associated elements occur in a high concentration and, furthermore, they are part of a group of elements considered critical by the European Union [7]. Twenty-seven raw materials are included in the critical raw materials which include: $\mathrm{Sb}$, barite, $\mathrm{Be}, \mathrm{Bi}$, borate, $\mathrm{Co}$, coking coal, fluorite, $\mathrm{Ga}, \mathrm{Ge}, \mathrm{Hf}, \mathrm{He}, \mathrm{In}, \mathrm{Mg}$, natural graphite, natural rubber, $\mathrm{Nb}$, phosphorites, $\mathrm{P}, \mathrm{Sc}$, metallic silicon, $\mathrm{Ta}, \mathrm{W}, \mathrm{V}$, metals from the platinum group, and heavy and light rare earth elements. Critical elements are defined as elements that are of vital importance to modern technology and society and have the potential for supply restriction. These commodities are important components in the manufacturing of modern and green technology, have a wide variety of military applications, and are becoming increasingly important for high-tech applications. Consequently, a number of countries, including USA, UK, Japan, EU, and Australia have commissioned reports on critical commodities (e.g., [7,9-12]). Most of these commodities have small restricted markets, and supply is restricted, i.e., concentrated in either a small group of countries or operating companies [12,86-89]. The critical elements are generally produced in relatively small amounts or almost entirely as by-products of the mining of principal commodities [90-92]. Although the by-product elements have significant technological value, they are of lesser economic value than the main products of a given mining operation. Therefore, they are less likely to form part of companies' core business, and hence to be recovered. The potentially low concentrations of critical metals within a given mineral deposit are not be even determined based on the assumption that these commodities are of insignificant value. This means that a significant number of critical metals are unreported or are ignored at the mineral resource reports. Mining companies focus on the most dominant economically valuable commodities in a mine or exploration programs, and therefore critical commodities that have small markets or that are difficult to extract are often ignored. According to numerous studies, the most critical commodities for the EU and Polish economy are rare earths (REE), Nb, and Ta, for which there are no primary and secondary sources in the EU and no possibility of their production [8,9]. Generally, critical raw materials are in short supply [10-12] as there are only primary (from deposits) and secondary (recycling) sources for them within the EU, usually with insufficient resources; nevertheless, a demand for them is easily covered to a large extent by imports from countries outside the EU [8]. However, some of these elements are present in large stocks in metal ore deposits in Europe, but they are not recovered in technological processes. Some sediment-hosted deposits contain critical elements that are, or potentially could be, extracted $[12,13,85,86,90]$. 
Table 11. Associated elements and enrichment factors relative to their abundances in the Earth's crust after [93] in the Zn-Pb (MVT) and Cu-Ag (Kupferschiefer) sediment hosted deposits in Poland.

\begin{tabular}{|c|c|c|c|c|c|c|c|}
\hline Deposit Type & Associated E & nts & Arithmetic Mean (ppm) & Median (ppm) & $\mathbf{N}$ & $\begin{array}{c}\text { Clark in the } \\
\text { Earth's Crust } \\
\text { [93] (ppm) }\end{array}$ & $\begin{array}{c}\text { Enrichment Factor } \\
\text { Arithmetic Mean/Clark in } \\
\text { Earth's Crust }\end{array}$ \\
\hline \multirow{8}{*}{$\mathrm{Zn}-\mathrm{Pb}$} & \multirow{5}{*}{ Critical elements } & $\mathrm{Ga}$ & 44.0 & 31.0 & 63 & 18 & $\times 2.4$ \\
\hline & & Hf & 24.9 & 1.5 & 63 & 5.3 & $\times 4.7$ \\
\hline & & $\mathrm{Nb}$ & 7.3 & 6.0 & 63 & 20 & $\times 0.4$ \\
\hline & & $\mathrm{Ba}$ & $11,271.2$ & 43.0 & 64 & 340 & $\times 33.2$ \\
\hline & & Sc & 2.3 & 2.3 & 66 & 16 & $\times 0.1$ \\
\hline & \multirow{3}{*}{$\begin{array}{l}\text { Non-critical } \\
\text { elements }\end{array}$} & $\mathrm{Ag}$ & 13.4 & 9.9 & 66 & 0.07 & $\times 191.4$ \\
\hline & & $\mathrm{Cd}$ & 440.2 & 298.0 & 66 & 0.11 & $\times 4001$ \\
\hline & & $\mathrm{Tl}$ & 7.6 & 2.7 & 66 & 0.6 & $\times 12.7$ \\
\hline \multirow{7}{*}{$\mathrm{Cu}-\mathrm{Ag}$} & \multirow{2}{*}{ Critical elements } & Co & 243.3 & 61.7 & 71 & 20 & $\times 12.2$ \\
\hline & & $\mathrm{V}$ & 740.2 & 497.0 & 71 & 160 & $\times 4.6$ \\
\hline & \multirow{5}{*}{$\begin{array}{c}\text { Non-critical } \\
\text { elements }\end{array}$} & $\operatorname{Re}$ & 5.8 & 0.89 & 71 & 0.0004 & $\times 14,567$ \\
\hline & & Se & 28.8 & 21.0 & 71 & 0.05 & $\times 575.2$ \\
\hline & & $\mathrm{Ni}$ & 194.1 & 117.0 & 71 & 80 & $\times 2.4$ \\
\hline & & ${ }^{*} \mathrm{Ag}$ & 67.9 & 43.9 & 71 & 0.07 & $\times 970$ \\
\hline & & $\mathrm{Bi}$ & 5.0 & 0.5 & 71 & 0.048 & $\times 104.1$ \\
\hline
\end{tabular}


Table 12. Trace elements with the highest enrichment rates and estimated resources in documented $\mathrm{Zn}-\mathrm{Pb}$ and $\mathrm{Cu}-\mathrm{Ag}$ sediment hosted deposits in Poland considered as having potential economic profitability of extraction from the studied ores.

\begin{tabular}{|c|c|c|c|c|c|c|c|}
\hline \multirow{2}{*}{$\begin{array}{l}\text { Associate } \\
\text { Element }\end{array}$} & \multicolumn{3}{|c|}{$\mathrm{Zn}-\mathrm{Pb}$ (MVT) } & \multicolumn{4}{|c|}{ Cu-Ag (Kupferschiefer) } \\
\hline & $\begin{array}{l}\text { Enrichment } \\
\text { Factor }\end{array}$ & $\begin{array}{c}\text { Resources Estimated } \\
{[4] \text { (ton) }}\end{array}$ & $\begin{array}{c}\text { Resources Identified } \\
\text { [1] (ton) }\end{array}$ & $\begin{array}{l}\text { Enrichment } \\
\text { Factor }\end{array}$ & $\begin{array}{l}\text { Resources [4] } \\
\text { (ton) }\end{array}$ & $\begin{array}{l}\text { Resources Identified [1] } \\
\text { (ton) }\end{array}$ & $\begin{array}{c}\text { By-Product of the SSC } \\
\text { Deposits in } 2018 \text { [1] (ton) }\end{array}$ \\
\hline \multicolumn{8}{|c|}{$\begin{array}{ll}\text { Trace (critical) Elements } \\
\end{array}$} \\
\hline $\mathrm{Ga}$ & low & $>1000$ & 130 & & & & \\
\hline $\mathrm{Ge}$ & - & - & 30 & & & & \\
\hline $\mathrm{Hf}$ & low & - & & & & & \\
\hline Co & & & & high & $>100,000$ & 137,440 & \\
\hline $\mathrm{Nb}$ & low & - & & & & & \\
\hline $\mathrm{V}$ & & & & low & $>100,000$ & 171,410 & \\
\hline $\mathrm{Ba}$ & high & $>500,000$ & & & & & \\
\hline \multicolumn{8}{|c|}{ Trace (non-critical) elements } \\
\hline $\mathrm{Cr}$ & very low & $>1000$ & & & & & \\
\hline $\mathrm{Cd}$ & high & $>20,000$ & 21,770 & & & & \\
\hline Mo & & & & high & $>100,000$ & 73,040 & \\
\hline $\begin{array}{c}{ }^{*} \mathrm{Ni} \text { (as } \\
\text { Ni-sulfate) }\end{array}$ & & & & low & $>100,000$ & 82,270 & 1730 \\
\hline${ }^{*} \operatorname{Re}$ & & & high & high & $>10,000$ & & 9.09 \\
\hline${ }^{*} \mathrm{Se}$ & & & & high & $>10,000$ & & 66.36 \\
\hline $\mathrm{Tl}$ & low & 400 & 150 & & $>1000$ & & \\
\hline${ }^{*} \mathrm{Au}$ & & & & & & & 0.523 \\
\hline${ }^{*} \mathrm{Pt}-\mathrm{Pd}$ & & & & & & & \\
\hline
\end{tabular}


The most common critical elements associated with the MVT deposits are Ga, Ge, In, and Ba and those from the sediment-hosted deposits are Co, Ga, Ge, In, Pt, Pd, and Re [13]. The Polish Zn-Pb ores also contain many critical elements, but they are not recovered during the processing of these ores. Only some of critical elements (Pd and $\mathrm{Pt}$ ) are recovered in the processing of $\mathrm{Cu}-\mathrm{Ag}$ ores in Poland (Table 12), and knowledge about their distribution is still insufficient $[4,14,15]$.

Among the trace elements currently considered critical for the EU economy [7] in the sulfide ores from the $\mathrm{Zn}-\mathrm{Pb}$ and $\mathrm{Cu}-\mathrm{Ag}$ deposits in Poland, the following elements were examined: $\mathrm{Sb}, \mathrm{Bi}, \mathrm{Co}, \mathrm{Ga}$, $\mathrm{Hf}, \mathrm{In}, \mathrm{Nb}, \mathrm{Sc}, \mathrm{Ta}, \mathrm{W}, \mathrm{V}, \mathrm{Pd}, \mathrm{Pt}$, and REE + Y. Our studies have shown that the critical elements for the EU economy occur in very diverse concentrations ranging from trace amounts to significantly increased contents. The $\mathrm{Cu}$-Ag ores contain several critical elements, such as $\mathrm{V}, \mathrm{Co}, \mathrm{Bi}, \mathrm{Pt}$, and $\mathrm{Sb}$ that show enrichment of their average arithmetic mean content in relation to their abundances in the Earth's crust (Figure 20 and Table 11). Other critical elements, such as Ga, Hf, In, Sc, W, Ta, and REE are present in very low amounts. In order to distinguish associated elements with the potential economic profitability of extraction from the studied ores, it is assumed that this group should include those elements that meet the following criteria: high average content, high value of the enrichment factor (in relation to the Earth's crust contents, Table 12), and estimated resources over 100 tons per deposit. Table 12 lists enrichment factors and resource estimates, summarizing the classification of critical and non-critical elements with potential economic viability of recovery.

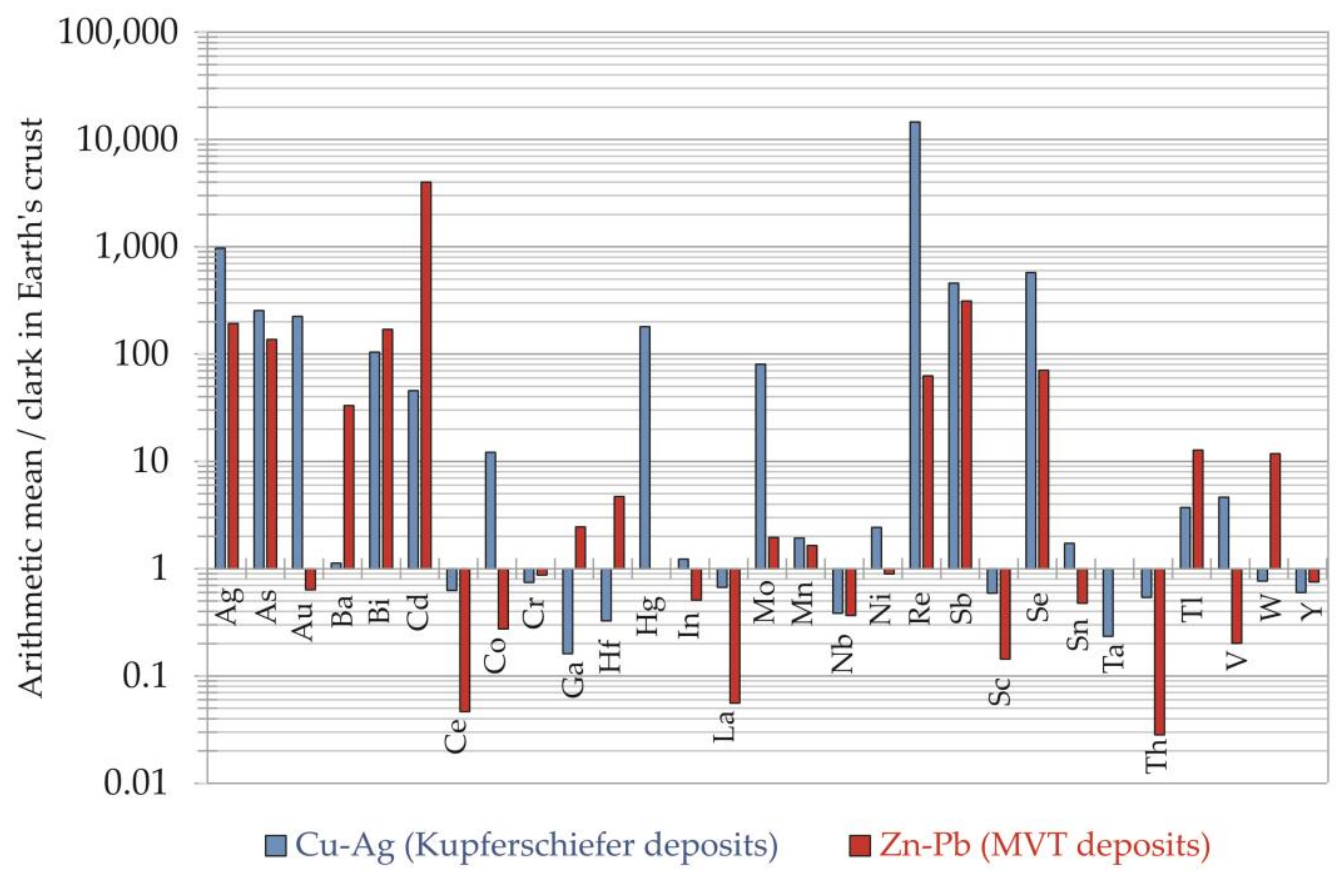

Figure 20. Comparison of the arithmetic mean content of trace elements in bulk-rock analyses of samples from the $\mathrm{Cu}-\mathrm{Ag}$ and $\mathrm{Zn}-\mathrm{Pb}$ sediment hosted deposits in Poland relative to their average contents in the Earth's crust [93].

In the $\mathrm{Zn}-\mathrm{Pb}$ deposits, the distribution of trace elements (e.g., $\mathrm{Cd}, \mathrm{Ag}$, $\mathrm{Ga}$, In, and $\mathrm{Ge}$ ) is typical for this type of deposits $[14,15,28,29,36,75,76]$. The considered $\mathrm{Zn}-\mathrm{Pb}$ sulfide ores were represented mainly by sphalerite \pm galena \pm pyrite/marcasite and contain critical elements such as $\mathrm{Ge}, \mathrm{In}, \mathrm{Ga}$, $\mathrm{Sc}, \mathrm{Hf}, \mathrm{Nb}$, and $\mathrm{Ba}$. In the studied samples, their average contents and enrichment factors are low. In the plot comparing the arithmetic mean of elements content to their content in the Earth's crust [93], it is evident that several critical elements, such as $\mathrm{Ga}$, In, $\mathrm{Hf}, \mathrm{Nb}, \mathrm{Sc}, \mathrm{V}, \mathrm{Co}, \mathrm{W}, \mathrm{Pt}, \mathrm{Pd}$, and REE show depletion of their concentrations in the Earth's crust (Figure 20). For this reason, their recovery is technically and economically unviable. Only gallium, despite the low enrichment factor $(x 2.4$, Table 12, arithmetic average $=44 \mathrm{ppm}$, maximum $\leq 177 \mathrm{ppm}$ ), has high estimated resources, so it 
could be recovered, as in other MVT deposits [11-13]. For the Zawiercie 3 deposit, it is estimated at 130 tons of Ga [1], and for the entire area > 1000 tons (Table 12). Currently, Ga is not recovered [87], but formerly it was obtained at the Szopienice smelter after dusting with sphalerite concentrates [15]. Its distribution is associated with $\mathrm{Zn}$. Indium concentrations are at a very low level $<0.01 \mathrm{ppm}$ (close to detection limit), similar to its concentrations in sphalerite $(\leq 300 \mathrm{ppm})$. The arithmetic average for Hf is high in whole rock samples (Figure 21) and amounts to $25 \mathrm{ppm}$ (maximum content up to $314 \mathrm{ppm}$ ), but the enrichment factor is small. Germanium resources in the Zawiercie 3 deposit were estimated at about 30 tons [1] and if its higher concentrations were found, it could be obtained during metallurgical processing of Zn sulfide concentrates, as in several other MVT deposits [13]. Ba is a very interesting element accompanying $\mathrm{Zn}-\mathrm{Pb}$ ores showing high average concentrations $(1.13 \%$ and maximum $11.7 \%$ ) in the samples studied. It is present in the form of barite, which postdates the ore stage of mineralization, and in numerous samples overprinted galena mineralization. Barium is not recovered in technological processes, although barite can be easily enriched from ores by gravity methods. Cadmium is an important trace element not recovered in the processing of $\mathrm{Zn}-\mathrm{Pb}$ ores [14]. Arithmetic mean of $\mathrm{Cd}$ in the samples $=440.2 \mathrm{ppm}($ maximum $=2100 \mathrm{ppm})$, and for $\mathrm{Ag}$ it is $13.4 \mathrm{ppm}$ (maximum $=102.7 \mathrm{ppm}$ ). The estimated $\mathrm{Cd}$ and $\mathrm{Ag}$ resources in nine deposits in this region are 21,770 tons and 930 tons, respectively [1]. Cadmium shows a very strong correlation with $\mathrm{Zn}$ distribution $(r=0.90)$ and weaker with $\mathrm{Ag}(\mathrm{r}=0.64)$. Electron probe microanalysis research showed that the main carrier of $\mathrm{Ag}$ in the Zawiercie $\mathrm{Zn}-\mathrm{Pb}$ deposit is sphalerite of different types (maximum $=3310 \mathrm{ppm}$ ), and in the negligible range galena (maximum $=730 \mathrm{ppm}$ ). In turn, galena proved to be a carrier of $\mathrm{Sb}$ (arithmetic mean $=1132 \mathrm{ppm}$ and maximum $\leq 1.87 \mathrm{wt} \%$ ).

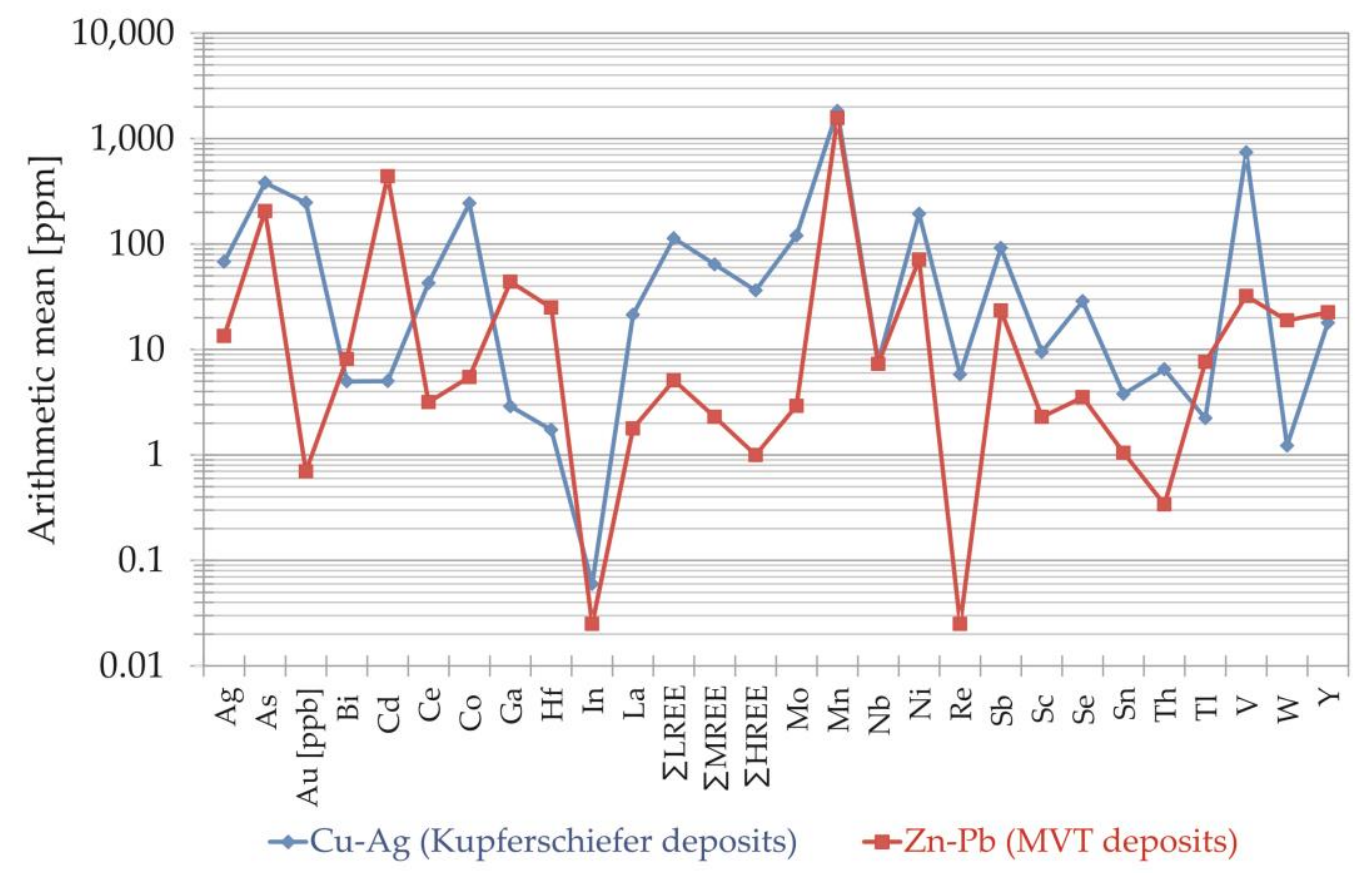

Figure 21. Comparison of arithmetic mean values of selected trace elements in the bulk-rock analyses of $\mathrm{Zn}-\mathrm{Pb}$ (MVT) and $\mathrm{Cu}-\mathrm{Ag}$ (Kupferschiefer) sediment hosted deposits in Poland.

The presence of some toxic elements, $\mathrm{Cr}$ and $\mathrm{Tl}$, was also found in $\mathrm{Zn}-\mathrm{Pb}$ sulfide ores, although their estimated resources are significant, they are characterized by low enrichment factor (Table 12). Arsenic is also a toxic element, which, unlike $\mathrm{Tl}$, has enrichment (about $\times 13$ ) and is strongly associated with the presence of pyrite/marcasite in $\mathrm{Zn}-\mathrm{Pb}$ ores. Admixtures of As in pyrites are on average around $2237 \mathrm{ppm}$ (maximum $=2.7 \mathrm{wt} \%$ ).

The $\mathrm{Cu}-\mathrm{Ag}$ ores are highly enriched in associated elements, such as $\mathrm{Au}, \mathrm{Pb}, \mathrm{Ni}, \mathrm{Re}$, and $\mathrm{Se}$ (recovered) and Co, V, Mo, Hg, and Bi (not recovered) (Tables 6 and 12), [53,55,62-67,81,87,89,94-100]. 
In smaller quantities there are PGE and REE. The group of elements critical for the EU include the following: $\mathrm{Co}, \mathrm{V}, \mathrm{Bi}, \mathrm{Sb}, \mathrm{Sc}, \mathrm{PGE}$, and REE.

Among the critical elements, Co is particularly noteworthy [95-97]. The samples tested showed a high arithmetic average content of $\mathrm{Co}=243.3 \mathrm{ppm}$ (maximum $5630 \mathrm{ppm}$ ) and an increased enrichment factor $(>\times 12$, Table 11). Its distribution is strongly associated with the presence of Co and Ni minerals in sulfide ore. Among them, sulfosalts dominate (cobaltite CoAsS and gersdorffite NiAsS), arsenides (skutterudite $\mathrm{CoAs}_{3}$ and safflorite $\left[(\mathrm{Co}, \mathrm{Fe}) \mathrm{As}_{2}\right]$ ) are also common and sulfides (from siegenite group $(\mathrm{Co}, \mathrm{Ni})_{3} \mathrm{~S}_{4}$ and rammelsbergite $\left.\mathrm{NiS}_{2}\right)$ are rare. The second form of occurrence of $\mathrm{Co}$ and $\mathrm{Ni}$ are isomorphic substitutions of other metals in ore minerals, especially in pyrite [65]. Our EPMA research confirmed high admixtures of Co in the transient pyrite phases (up to $4950 \mathrm{ppm}$, along with $\mathrm{Cu}$ $(\leq 21.0 \mathrm{wt} \%)$, As $(\leq 4190 \mathrm{ppm}), \mathrm{Ni}(\leq 1100 \mathrm{ppm})$, and Mo $(\leq 9790 \mathrm{ppm})$ admixtures. The estimated Co identified resources in nine $\mathrm{Cu}-\mathrm{Ag}$ deposits considered here are large as they amount to 137,440 tons [1] at average content of $243.3 \mathrm{ppm}$ (Table 12). However, despite the favorable parameters, Co is not recovered, because it goes to silicate slag in the process of converting, and separation of Co requires expensive technology. Nevertheless, it is still possible to extract Co hydroxide from wastes obtaining at various stages of metallurgical processing of $\mathrm{Cu}-\mathrm{Ag}$ ores $[66,84,98]$. Vanadium is another important critical element with significant reported resources, approximately 171,410 tons (in seven deposits) [1], which is also not recovered in the processing of the $\mathrm{Cu}$-Ag sulfide ores. According to our research, its arithmetic mean content in the studied bulk-rock ore samples is $740.2 \mathrm{ppm}$ (maximum $2393 \mathrm{ppm} \mathrm{V}$ ). However, its enrichment factor is not very high $(\times 4.6)$. Although it shows a strong correlation $(r=0.90)$ and weaker with extracted $\mathrm{Se}$ and $\mathrm{Cu}(\mathrm{r}=0.63), \mathrm{V}$ recovery is considered unprofitable. It should be noted that $\mathrm{V}$ has a strong correlation with other strategic elements, i.e., $\mathrm{Ta}(\mathrm{r}=0.71)$, $\mathrm{Hf}$ and $\mathrm{Sc}$ $(\mathrm{r}=\sim 0.70)$.

Other critical elements, $\mathrm{Bi}, \mathrm{Sb}$, and $\mathrm{Sc}$ with relatively high estimated resources are also present in $\mathrm{Cu}-\mathrm{Ag}$ deposits (Table 12) but due to the low values of the enrichment factor, their extraction possibility is limited. It should be noted that in the economics of the entire sulfide ore processing (chalcocite \pm bornite \pm chalcopyrite with a differentiated proportion of $\mathrm{Zn}$-Pb-Fe sulfides), low contents of some critical elements should not be decisive for their recovery, because many of them are enriched in the phase of mechanical processing and flotation, as well as during metallurgical smelting of $\mathrm{Cu}$ concentrates and metal refining processes.

Platinum group metals are recovered from the anode slimes produced during the electrolytic refining of $\mathrm{Cu}-\mathrm{Ag}$ ores, meanwhile they have higher concentrations in the oxidized Rote Fäule rocks that are not mined. Similarly, Au and REE (especially MREE, cf. Figure 17B) are present in larger amounts in oxidized, rather than reducing, rocks $[78,80-83,100]$. Because oxidized rocks are barren in $\mathrm{Cu}$ and $\mathrm{Ag}$, production of $\mathrm{Au}, \mathrm{PGE}$, and REE (especially MREE) from oxidized rocks would require a selective operation and mining at a considerable distance from current mine workings. Nevertheless, the possibility of recovering both PGE, Au and REE, from oxidized rocks should be considered by current and future mining investors. As a result, current annual production (about 0.5 tons $\mathrm{Au}$, e.g., in 2018, $523 \mathrm{~kg}$ and several dozen $\mathrm{kg}$ of Pt-Pd slime [1]), could increase.

The $\mathrm{Cu}$-Ag deposits also contain non-critical elements (Re, Se, Mo, and Ni), of which Re, Se, and $\mathrm{Ni}$ are recovered. Rhenium occurs at a moderate content in the deposit (less than 1 ppm [94]), but with a significant concentration in relation to the Earths' crust exhibiting a very strong enrichment in relation to the Earth's crust $(\times 14,500$, Table 11$)$. It concentrates mainly in shale ore as an admixture in Mo minerals and in organic matter [65,67]. Rhenium shows a weak correlation with $\mathrm{Cu}$ and $\mathrm{V}$ $(\mathrm{r}=0.55)$. The average concentration of Re in the samples tested was $5.8 \mathrm{ppm}$ (maximum $68.7 \mathrm{ppm})$, however, mastering the technology of obtaining ammonium perrhenate from washing sulfuric acid allows its production, which, in 2018, amounted to 9.09 tons [1]. Selenium, despite low concentrations in the $\mathrm{Cu}-\mathrm{Ag}$ ore (arithmetic mean $=28.8 \mathrm{ppm}$ and maximum $109 \mathrm{ppm}$ ), is also recovered from anode slimes, which is supported by a high enrichment factor $(>\times 500)$ (Table 11). It occurs as a significant substitution for $\mathrm{S}$ in chalcocite (up to $1620 \mathrm{ppm}$ ), other $\mathrm{Cu}$ sulfides, and in galena [53,64,65]. A number 
of rare $\mathrm{Cu}-\mathrm{S}$ minerals (e.g., djurleite, roxbyite, geerite, and yarrowite) contain admixtures of Se (together with $\mathrm{Ag}, \mathrm{Zn}$, and Bi), less often as Se minerals (tiemannite and clausthalite). In addition, study of the oxidized samples showed significant admixture of Se in tennantite $(\leq 8.27 \mathrm{wt} \%)$. Estimated resources of Se are quite significant [4], and its production in 2018 amounted to 66.36 tons Se [1]. Nickel and Mo occur in significant resources in the $\mathrm{Cu}-\mathrm{Ag}$ deposits. Nickel resources are estimated at $87.27 \mathrm{kt}$ (in seven deposits) and Mo resources at approximately $73.04 \mathrm{kt}$ (in seven deposits), [1]. In the samples studied, the arithmetic means of $\mathrm{Ni}$ and Mo contents are relatively high (194 ppm and $120.3 \mathrm{ppm}$, respectively). Nickel and Mo show a mutually strong correlation $(\mathrm{r}=0.7)$ and a strong correlation with Co distribution and weaker with $\mathrm{Cu}$. Nickel is recovered as Ni sulfate, however, the recovery of Mo is still unprofitable, despite its relatively high content in the $\mathrm{Cu}-\mathrm{Ag}$ deposit, especially in shale ore $[67,84]$. Of the other associated elements, a high enrichment factor $(\times 500)$ reveled $\mathrm{Sb}$ and weaker $(\times 200) \mathrm{Hg}$, As, and Au, and much weaker Bi (×100) and Mo (×70) (Figure 20).

\subsection{Genetic Implications for Trace Element Enrichment}

$\mathrm{Zn}-\mathrm{Pb}$ (MVT) deposits in the Silesia-Cracow district formed as a result of the migration of warm (70 to $160^{\circ} \mathrm{C}$ ) highly saline ( 20 to $23 \mathrm{wt} \% \mathrm{CaCl}_{2}$ equivalent) and metal-bearing $\mathrm{Na}-\mathrm{Ca}-\mathrm{Cl}$ fluids into the Triassic host carbonates and precipitation of hydrothermal dolomite and sulfides [31]. The mineralizing fluids started migrating upward along faults in response to the Early Cretaceous crustal extension preceding the opening of the northern Atlantic Ocean. It is believed that the main source of metals was coal-bearing Carboniferous molasse sequence in the Upper Silesia coal basin that underline part of the $\mathrm{Zn}-\mathrm{Pb}$ district. This view is supported by results of the isotopic study of $\mathrm{Pb}$ in galena and sulfur in sulfides [36]. The $\delta^{34} S$ values of sulfides are in a very wide range from $+2 \%$ o to $+12 \%$ o (for one and two stages of ore mineral succession, Figure 9) and sulfides from stage three are characteristically depleted in $\delta^{34} \mathrm{~S}$, with $\delta^{34} \mathrm{~S}$ values mostly between $-2 \%$ and $-15 \%$ o [21,36], indicating reduced biogenic sulfur. The ore minerals precipitated from highly saline fluids enriched in $\mathrm{Na}^{+}$cations that were episodically introduced into the Triassic host rocks [31]. The content of trace elements in sulfides shows large variation between different paragenetic stages and as compared with world MVT deposits, the Silesian-Cracow ores contain sphalerite with the largest range of $\mathrm{Ag}, \mathrm{Fe}$, and $\mathrm{Cd}$. Thallium and $\mathrm{As}$ are remarkably high in some galena and sphalerite, reaching thousands ppm or even weight percent level $[28,29,36]$. These wide ranges in trace elements content can be interpreted as mixing fluids, for example, function of the complex $\mathrm{pH}$ chemistry of groundwater and ascending low temperature hydrothermal fluids during their migration through different geochemically distinct Mesozoic and Paleozoic formations $[5,21,28,29,34,35]$. This study confirmed that sphalerite contains substitutions such as $\mathrm{Zn}^{2+} \leftrightarrow \mathrm{Fe}^{2+}$ and $\mathrm{Zn}^{2+} \leftrightarrow \mathrm{Cd}^{2}$, as well as coupled substitutions of other trace elements, as suggested by Cook et al. [75].

In the case of the $\mathrm{Cu}-\mathrm{Ag}$ Kupferschiefer deposits, two main metal sources have been considered, i.e., rocks of the pre-Permian basement, and Rotliegend red beds and volcanic rocks [41,52-54,101,102]. Metals were leached by oxidizing chloride-rich solutions from labile mineral constituents of the red beds. The Kupferschiefer mineralization resulted from upward and laterally flowing fluids which oxidized originally pyritiferous organic matter-rich sediments to form hematitic Rote Fäule areas, which emplaced base and associated elements into reduced sediments. Long-lived and large-scale lateral fluid flow caused the cross-cutting relationships, expansion of the hematitic alteration front, redistribution of metals, and the location of $\mathrm{Cu}$ ore bodies directly above and around oxidized areas. As a result of fluid circulation, metals are distributed throughout the Lubin-Sieroszowice deposit depending on the distance from the feeder areas and the local geochemical environments. The metals are zoned both vertically and horizontally in the sequence $\mathrm{Fe}^{3+}(\mathrm{Au}, \mathrm{Pt}$, $\mathrm{Pd})-\mathrm{Cu}(\mathrm{Ag})-\mathrm{Pb}-\mathrm{Zn}-\mathrm{Fe}^{2+}$ in distinct zones around oxidized areas and typical paragenetic sequence includes hematite (goethite)-covellite-chalcocite-bornite-chalcopyrite-galena-sphalerite-pyrite in which hematite postdates sulfides. Cu-S-type sulfides are younger than $\mathrm{Cu}$-Fe-S-type sulfides and framboidal pyrite is the earliest $[52,53,55,56,58]$. This deposit is polymetallic, because Ag coexists with 
$\mathrm{Cu}$, and significant amounts of $\mathrm{Pb}, \mathrm{Zn}, \mathrm{Co}, \mathrm{Mo}, \mathrm{Ni}, \mathrm{V}, \mathrm{Se}$, and Re can also be associated locally with $\mathrm{Cu}$ mineralization [62-64]. Silver is more concentrated in ore in the eastern part of the Lubin-Sieroszowice deposit as compared with its western part [60]. Cobalt predominates over $\mathrm{Ni}$ in the western part of the Lubin-Sieroszowice deposit, while the relationship between them in the eastern part is the opposite [96-98]. Cobalt occurs as an associated metal with a relatively high average content of 50 to $80 \mathrm{ppm}$, however, it is difficult to apply an efficient technology for its recovery $[15,66,84,85,98]$. Vanadium is not recovered as it concentrates in organic matter (up to $5 \mathrm{wt} \%$ ) and its distribution in the ore series is not dependent on the intensity and type of mineralization [99]. In turn, Re concentrations are higher in the southern parts of the deposit than those in the northern parts [94]. Gold, platinum-group metals, and REE are restricted mostly to the oxidized rocks $[78,80-83,100]$. Regional arrangement of main and trace elements implies that they were extensively redistributed by upward and laterally spreading fluids. This is clearly evidenced by the telescoping nature of the mineralizing system and distinct zones around oxidized areas [53]. Gold, PGE, and MREE accumulated predominantly in the oxidized rocks but base and trace elements were removed from those rocks due to oxidative alteration and concentrated successively at the redox interface while the fluids migrated further out from the feeder areas.

\section{Conclusions}

Our geochemical and mineralogical investigation of ore-bearing samples from the sediment hosted $\mathrm{Zn}-\mathrm{Pb}$ (MVT) and $\mathrm{Cu}-\mathrm{Ag}$ Kupferschiefer (SSC) deposits confirms that it is necessary for mining investors to consider the possibility of recovering several elements not extracted until now as by-products from $\mathrm{Zn}-\mathrm{Pb}$ and $\mathrm{Cu}-\mathrm{Ag}$ sediment-hosted deposits. Among trace elements, $\mathrm{Ga}, \mathrm{Cd}, \mathrm{Ag}$, and $\mathrm{Ba}$ (to a lesser extent $\mathrm{Hf}, \mathrm{Sb}$, and $\mathrm{Sc}$ ) in $\mathrm{Zn}-\mathrm{Pb}$ deposits and $\mathrm{Co}, \mathrm{V}$, and $\mathrm{Mo}$ (to a lesser extent $\mathrm{Bi}$ and $\mathrm{Sb}$ ) in $\mathrm{Cu}-\mathrm{Ag}$ deposits deserve special attention, especially the critical elements of strategic importance. Their recovery does not currently seem profitable because of uneconomic concentrations and the lack of recovery technologies in processing and metallurgy. However, in the future, new technologies for the extraction of trace elements from ores and increasing demand should enable the production of these elements, despite their relatively low content in these deposits.

Author Contributions: Field work, S.Z.M., S.O., A.C., K.S., and R.M.; data analysis, S.Z.M. and S.O.; ore microscopy, A.C., K.S., and S.Z.M.; figures, S.Z.M., A.C., K.S., and R.M.; writing-original draft preparation, S.Z.M. and S.O.; writing-review and editing S.Z.M. and S.O. All authors have read and agreed to the published version of the manuscript.

Funding: This work is financially supported by the Polish Geological Institute-National Research Institute through an internal grant for publication no. 62.9012.1983.00.0 and by the National Fund for Environmental Protection and Water Management in accordance with agreement no. 506/2015 for S.M., as well as by the FRAME (Forecasting and Assessing Europe's Strategic Raw Materials Needs) project within the GeoERA grant (number 731166 H2020).

Acknowledgments: We are grateful to three anonymous reviewers for their constructive reviews and valuable suggestions that improved the first version of the manuscript.

Conflicts of Interest: The authors declare no conflict of interest. 


\section{Appendix A}

Table A1. Ore Minerals Recognized Microscopically in Studied Boreholes from the Cu-Ag Kupferschiefer Deposits on the Fore-Sudetic Monocline in Poland.

\begin{tabular}{|c|c|c|c|c|c|c|}
\hline \multirow[b]{2}{*}{ Borehole } & \multirow[b]{2}{*}{$\begin{array}{l}\text { Principal Ore } \\
\text { Mineral }\end{array}$} & \multirow[t]{2}{*}{ Zechstein Limestone (Ca1) } & \multicolumn{2}{|c|}{ Kupferschiefer (T1) } & \multicolumn{2}{|r|}{ Weissliegend (Ws) } \\
\hline & & & $\begin{array}{l}\text { Principal Ore } \\
\text { Mineral }\end{array}$ & Associated Minerals & $\begin{array}{l}\text { Principal Ore } \\
\text { Mineral }\end{array}$ & Associated Minerals \\
\hline S-389 & digenite & covellite, chalcocite, pyrite, hematite & covellite & digenite, hematite & - & - \\
\hline S-391 & digenite & $\begin{array}{l}\text { covellite, chalcocite, hematite, electrum, native } \\
\text { gold }\end{array}$ & chalcocite & digenite, covellite, bornite, hematite & chalcocite & hematite, goethite \\
\hline S-428 & digenite & covellite, bornite, electrum, native gold, hematite & chalcocite & hematite & chalcocite & hematite \\
\hline S-115 & sphalerite & galena, pyrite, chalcopyrite & galena & chalcopyrite, sphalerite, pyrite & chalcopyrite & sphalerite, galena, pyrite, bornite \\
\hline S-117 & chalcopyrite & bornite, sphalerite, covellite, galena & bornite & chalcopyrite, covellite, galena & bornite & covellite, sphalerite, galena, pyrite, chalcopyrite \\
\hline S-303 & pyrite & galena, sphalerite, chalcopyrite & - & - & bornite & chalcopyrite, covellite, digenite, galena, pyrite \\
\hline S-262 & digenite & chalcocite, bornite, pyrite & chalcocite & $\begin{array}{c}\text { digenite, bornite, covellite, } \\
\text { chalcopyrite, galena, sphalerite, pyrite }\end{array}$ & chalcocite & $\begin{array}{l}\text { digenite, covellite, bornite, chalcopyrite, pyrite, } \\
\text { Ag alloys }\end{array}$ \\
\hline S-269 & bornite & chalcopyrite, covellite, digenite, galena, chalcocite & - & - & chalcopyrite & hematite, goethite \\
\hline S-95 & chalcocite & digenite, chalcopyrite & digenite & chalcocite, Ag alloys & chalcocite & digenite, hematite \\
\hline S-99 & digenite & chalcocite, covellite, bornite & chalcocite & digenite, bornite, covellite & - & - \\
\hline S-192 & covellite & bornite, chalcopyrite, digenite & - & - & covellite & bornite, digenite, chalcocite, native $\mathrm{Au}$, hematite \\
\hline S-64 & digenite & $\begin{array}{l}\text { chalcocite, covellite, bornite, electrum, native } \\
\text { gold, hematite }\end{array}$ & digenite & $\begin{array}{l}\text { covellite, chalcopyrite, electrum, } \\
\text { hematite }\end{array}$ & chalcocite & covellite, hematite \\
\hline S-65 & digenite & covellite & chalcocite & bornite, digenite & digenite & $\begin{array}{l}\text { chalcocite, covellite, bornite, tennantite, electrum, } \\
\text { Ag alloys }\end{array}$ \\
\hline S-232 & chalcopyrite & galena, sphalerite, bornite, pyrite & - & - & galena & chalcopyrite, sphalerite, bornite \\
\hline S-171 & chalcocite & digenite, covellite, bornite & - & - & chalcocite & digenite, covellite, Ag alloys \\
\hline S-196 & digenite & chalcocite, covellite, bornite, chalcopyrite, galena & - & - & digenite & bornite, covellite, Ag alloys \\
\hline S-209 & chalcopyrite & bornite, covellite, galena, sphalerite, pyrite & - & - & bornite & chalcopyrite, galena, covellite, sphalerite \\
\hline S-39 & chalcopyrite & sphalerite, bornite & chalcocite & digenite, bornite, & hematite & goethite, chalcopyrite \\
\hline S-137 & chalcocite & digenite, bornite & chalcocite & $\begin{array}{l}\text { digenite, covellite, electrum, } \\
\text { tiemannite, hematite }\end{array}$ & chalcocite & covellite, hematite \\
\hline S-186 & digenite & bornite, covellite, chalcocite, chalcopyrite & digenite & $\begin{array}{l}\text { bornite, covellite, chalcocite, } \\
\text { chalcopyrite }\end{array}$ & chalcocite & digenite, covellite, galena, chalcopyrite, sphalerite \\
\hline
\end{tabular}




\section{References}

1. Malon, A.; Tymiński, M.; Mikulski, S.Z.; Oszczepalski, S. Metal resources. In The Balance of Mineral Resources in Poland as of 31.12.2018; Szuflicki, M., Malon, A., Tymiński, M., Eds.; Państwowy Instytut Geologiczny: Warszawa, Poland, 2019; pp. 51-68. (In Polish)

2. Szuwarzyński, M. Ore bodies in the Silesia-Cracow Zn-Pb ore district, Poland. Pr. Państw. Inst. Geol. 1996, 154, 9-24.

3. Górecka, E. Geological setting of the Silesian-Kraków Zn-Pb deposits. Geol. Q. 1993, 37, 127-146.

4. Mikulski, S.Z.; Oszczepalski, S.; Sadłowska, K.; Chmielewski, A.; Małek, R. The occurrence of associated and critical elements in selected documented $\mathrm{Zn}-\mathrm{Pb}, \mathrm{Cu}-\mathrm{Ag}$, Fe-Ti-V, Mo-Cu-W, $\mathrm{Sn}, \mathrm{Au}-\mathrm{As}$ and Ni deposits in Poland. Biul. Państw. Inst. Geol. 2018, 472, 21-52. (In Polish) [CrossRef]

5. Leach, D.L.; Sangster, D.F.; Kelley, K.D.; Large, R.R.; Garven, G.; Allen, C.R. Sediment-hosted Pb-Zn Deposits: A global perspective. Econ. Geol. 2005, 100, 561-608.

6. Gruszczyk, H.; Wielgomas, L. Zinc and lead ores in the Silesia-Kraków Triassic. In Geology of Poland: Mineral Deposits; Osika, R., Ed.; Wydawnictwa Geologiczne: Warsaw, Poland, 1990; Volume 6, pp. 172-177.

7. Communication from the Commission to the European Parliament, The Council. The European Economic and Social Committee and the Committee of the Regions on the 2017 List of Critical Raw Materials for the EU; European Commission: Brussels, Belgium, 2017; pp. 1-8.

8. Moss, R.L.; Tzimas, E.; Kara, H.; Willis, P.; Kooroshy, J. Critical metals in strategic energy technologies. Assessing rare metals as Supply-chain bottlenecks in low-carbon energy technologies. In European Commission Joint Research Centre Institute for Energy and Transport; Publication Office of the European Union: Luxembourg, 2011; pp. 1-159.

9. Weng, Z.; Jowitt, S.M.; Mudd, G.M.; Haque, N.A. Detailed Assessment of Global Rare Earth Resources: Opportunities and Challenges. Econ. Geol. 2015, 110, 1925-1952. [CrossRef]

10. Werner, T.T.; Ciacci, L.; Mudd, G.M.; Reck, B.K.; Northey, S.A. Looking Down Under for a Circular Economy of Indium. Env. Sci. Technol. 2018, 52, 2055-2062. [CrossRef]

11. Yellishetty, M.; Huston, D.; Graedel, T.; Werner, T.T.; Reck, B.K.; Mudd, G.M. Quantifying the Potential for Recoverable Resources of Gallium, Germanium and Antimony as Companion Metals in Australia. Ore Geol. Rev. 2017, 82, 148-159. [CrossRef]

12. Mudd, G.M.; Werner, T.T.; Weng, Z.H.; Yellishetty, M.; Yuan, Y.; McAlpine, S.R.B.; Skirrow, R.; Czarnota, K. Critical Minerals in Australia: A review of opportunities and research needs. Geosci. Aust. Rec. 2018, 51, $1-29$.

13. Marsh, E.E.; Hitzman, M.W.; Leach, D.L. Critical Elements in Sediment-Hosted Deposits (Clastic-Dominated $\mathrm{Zn}-\mathrm{Pb}-\mathrm{Ag}$, Mississippi Valley-Type Zn-Pb, Sedimentary Rock-Hosted Stratiform Cu, and Carbonate-Hosted Polymetallic Deposits): A Review. Rev. Econ. Geol. 2016, 18, 307-321.

14. Paulo, A.; Strzelska-Smakowska, B. Non-Ferrous and Precious Metal Ores; Wyd. AGH: Kraków, Poland, 2000. (In Polish)

15. Paulo, A.; Krzak, M. Rare Metals; Wyd. AGH: Kraków, Poland, 2015. (In Polish)

16. Żaba, J. The structural evolution of Lower Palaeozoic succession in the Upper Silesia and Małopolska block border zone (Southern Poland). Pr. Państw. Inst. Geol. 1999, 166, 1-162.

17. Żelaźniewicz, A.; Obec-Dziedzic, T.; Fanning, C.M.; Protas, A.; Muszyński, A. Late Carboniferous-Early Permian events in the Trans-European Suture Zone: Tectonic and acid magmatic evidence from Poland. Tectonophysics 2016, 675, 227-243. [CrossRef]

18. Szamałek, K.; Szuflicki, M.; Malon, A.; Tymiński, M. (Eds.) Mineral Resources of Poland; Polish Geological Institute-National Research Institute: Warszawa, Poland, 2017.

19. Szulc, J. Anisian-Carnian evolution of the Germanic basin and its eustatic, tectonic and climate controls. Zbl. Geol. Palaeontol. T.I.H 1999, 7-8, 813-852.

20. Górecka, E.; Leach, D.L.; Kozłowski, A. (Eds.) Carbonate-Hosted Zinc-Lead Deposits in the Silesian-Cracow Area, Poland; Prace/Panstwowy Instytut Geologiczny: Warszawa, Poland, 1996.

21. Leach, D.L.; Viets, J.G.; Kozłowski, A.; Kibitlewski, S. Geology, geochemistry, and Genesis of the Silesia-Kraków zinc-lead district, southern Poland. Soc. Econ. Geol. Spec. Publ. 1996, 4, 171-181. 
22. Sass-Gustkiewicz, M.; Dżułyński, S.; Ridge, J.D. The emplacement of zinc-lead sulfide ores in the Upper Silesian district-A contribution to the understanding of Mississippi Valley-type deposits. Econ. Geol. 1982, 77, 392-412. [CrossRef]

23. Przeniosło, S. An outline of the metallogeny of zinc and lead ores in the Silesian-Cracovian region. In The Current Metallogenic Problems of Central Europe; Fedak, J., Ed.; Wydawnictwa Geologiczne: Warszawa, Poland, 1976; pp. 367-384.

24. Mikulski, S.Z.; Strzelska-Smakowska, B.; Retman, W. The prospective and prognostic areas of zinc and lead ores in the Upper Silesia Zn-Pb Ore District. Gospod. Surowcami Miner. Resour. Manag. 2013, 29, 173-191.

25. Mikulski, S.Z.; Nowacki, Ł.; Sadłowska, K.; Ostrowski, S.; Bak, T.; Pacanowski, G.; Lasocki, M. Modern prospecting for zinc and lead ores of the MVT near Siewierz in the Upper Silesia Zn-Pb Ore District in the southern Poland. In Proceedings of the 14th SGA Biennial Meeting, Quebec City, PQ, Canada, 20-23 August 2017; Volume 2, pp. 681-684.

26. Leach, D.L.; Viets, J.G.; Powell, J.W. Textures of ores from the Silesian-Kraków zinc-lead deposits, Poland: Clues to the ore-forming environment. Pr. Inst. Geol. 1996, 154, 37-50.

27. Sass-Gustkiewicz, M. Revised and completed paragenetic order of minerals on the Pomorzany lead-zinc deposit, Upper Silesian region, Poland. Miner. Pol. 1997, 28, 46-80.

28. Viets, J.G.; Leach, D.I.; Lichte, F.E.; Hopkins, R.T.; Gent, C.A.; Powell, J.W. Paragenetic and minor- and trace-element studies of Mississippi Valley-type ore deposits of the Silesia-Cracow district, Poland. Pr. Panstw. Inst. Geol. 1996, 154, 51-70.

29. Harańczyk, C. Geochemistry of the ore minerals from Silesia-Cracow zinc and lead deposits. Pr. Geol. 1965, $30,1-111$.

30. Kozłowski, A.; Górecka, E. Sphalerite origin in the Olkusz mining district: A fluid inclusion model. Geol. Q. 1993, 37, 291-306.

31. Heijlen, W.; Muchez, P.; Banks, D.A.; Schneider, J.; Kucha, H.; Keppens, E. Carbonate-hosted Zn-Pb deposits in Upper Silesia, Poland: Origin and evolution mineralizing fluids and constrains on genetic models. Econ. Geol. 2003, 98, 911-932. [CrossRef]

32. Sass-Gustkiewicz, M.; Kwiecińska, B. Organic master in the Upper Silesian (Mississippi Valley-type) Zn-Pb deposits, Poland. Econ. Geol. 1999, 94, 981-992. [CrossRef]

33. Wodzicki, A. Origin of the Cracovian-Silesian Zn-Pb deposits. Ann. Soc. Geol. Pol. 1987, 57, 3-36.

34. Sass-Gustkiewicz, M. Internal sediments as a key to understanding the hydrothermal karst origin of the Upper Silesian Zn-Pb ore deposits. Soc. Econ. Geol. Spec. Publ. 1996, 4, 171-181.

35. Kozłowski, A.; Leach, D.L.; Viets, J.G. Genetic characteristics of fluid inclusions in sphalerite from the Silesian-Kraków ores, Poland. Pr. Państw. Inst. Geol. 1996, 154, 73-83.

36. Church, S.E.; Vaughn, R.B.; Gent, C.A.; Hopkins, R.T. Lead-isotopic, sulphur-isotopic and trace-elements studies of galena from the Silesian-Cracow $\mathrm{Zn}-\mathrm{Pb}$ ores, polymetallic veins from the Góry Świętokrzyskie Mts. and the Myszków porphyry copper deposit, Poland. Pr. Państw. Inst. Geol. 1996, 154, 139-156.

37. Coppola, V.; Boni, M.; Gilg, A.; Strzelska-Smakowska, B. Non-sulfide zinc deposits in the Silesia-Cracow district, Southern Poland. Miner. Depos. 2009, 44, 559-580. [CrossRef]

38. Sass-Gustkiewicz, M. Ore-forming processes in the Upper Silesian $\mathrm{Zn}-\mathrm{Pb}$ ore deposits. In Proceedings of the Fore-Sudetic Cu-Ag ore deposits \& Upper Silesia Zn-Pb Ore Deposits, Post Conference Field Trip 7 Guide-Poland, Kraków, Poland, 20-23 August 2007; pp. 77-97.

39. Symmons, D.T.A.; Sangster, D.F.; Leach, D.A. Teritary age from paleomagnetism for the Mississippi Valley-type zinc-lead mineralization in Upper Silesia. Econ. Geol. 1995, 90, 782-794. [CrossRef]

40. Doornenbal, J.C.; Stevenson, A.G. Petroleum Geological Atlas of the Southern Permian Basin Area; EAGE Publications: Houten, The Netherlands, 2010.

41. Oszczepalski, S. Kupferschiefer in southwestern Poland: Sedimentary environments, metal zoning, and ore controls. In Sediment-Hosted Stratiform Copper Deposits; Boyle, R.W., Brown, A.C., Jowett, E.C., Kirkham, R.V., Eds.; Geological Association of Canada Special Paper 36; Geological Association of Canada: Ottawa, ON, Canada, 1989; pp. 571-600.

42. Peryt, T.; Durakiewicz, T.; Kotarba, M.J.; Oszczepalski, S.; Peryt, D. Carbon isotope stratigraphy of the basal Zechstein (Lopingian) strata in Northern Poland and its global correlation. Geol. Q. 2012, 56, 285-298. [CrossRef] 
43. Jowett, E.C.; Pearce, G.W.; Rydzewski, A. A Mid-Triassic paleomagnetic age of the Kupferschiefer mineralization in Poland based on a revised apparent polar wander path for Europe and Russia. J. Geophys. Res. 1987, 92, 581-598. [CrossRef]

44. Nawrocki, J. Clay mineralogy, crystallinity, and K-Ar ages of illites within the Polish Zechstein Basin: Implications for the age of Kupferschiefer mineralization-A discussion. Econ. Geol. 2000, 95, 241-242. [CrossRef]

45. Mikulski, S.Z.; Stein, H.J. Re-Os age of a chalcopyrite sample from the Lubin Cu-Ag mine, Kupferschiefer, SW Poland. Geochim. Cosmochim. Acta 2010, 74, A708.

46. Mikulski, S.Z.; Stein, H.J. Re-Os ages for Ag-bearing Cu sulfide ores from the Kupferschiefer in Poland. In Mineral Resources in a Sustainable World, Proceedings of the 13th Biennial SGA Meeting, Nancy, France, 24-27 August 2015; Andre-Mayer, A.S., Cathelineau, M., Muchez, P., Pirard, E., Sindern, S., Eds.; Université de Lorraine: Nancy, France, 2015; Volume 2, pp. 607-610.

47. Bechtel, A.; Elliott, W.C.; Wampler, J.M.; Oszczepalski, S. Clay mineralogy, crystallinity, and K-Ar ages of illites within the Polish Zechstein basin: Implications for the age of Kupferschiefer mineralization. Econ. Geol. 1999, 94, 261-272. [CrossRef]

48. Michalik, M. Diagenesis of the Weissliegend sandstones in the south-western margin of the Polish Rotliegend basin. Pr. Miner. 2001, 91, 3-171.

49. Michalik, M.; Sawłowicz, Z. Multi-stage and long term origin of the Kupferschiefer copper deposits in Poland. In Mineral Deposits at the Beginning of the 21st Century; Piestrzyński, A., Speczik, S., Pasava, J., Gize, A., Sass-Gustkiewicz, M., Leach, D., Muchez, P., Oszczepalski, S., Brown, A., Blundell, D.J., et al., Eds.; Balkema: Rotterdam, The Netherlands, 2001; pp. 235-238.

50. Pašava, J.; Oszczepalski, S.; Du, A.D. Re-Os age of non-mineralized black shale from the Kupferschiefer, Poland, and implications for metal enrichment. Miner. Depos. 2010, 45, 189-199. [CrossRef]

51. Alderton, D.; Selby, D.; Kucha, H.; Blundell, D. A multistage origin for Kupferschiefer mineralization. Ore Geol. Rev. 2016, 79, 535-543. [CrossRef]

52. Rydzewski, A. Petrographic and Mineralogical Characteristics of Lower Zechstein Deposits in the Area of the Lubin-Sieroszowice Copper Deposit; Wyd. Geol.: Warszawa, Poland, 1964; pp. 59-84. (In Polish)

53. Oszczepalski, S. Origin of the Kupferschiefer polymetallic mineralization in Poland. Miner. Depos. 1999, 34 , 599-613. [CrossRef]

54. Kucha, H. Geology, mineralogy and geochemistry of the Kupferschiefer, Poland. In Europe's Major Base Metal Deposits; Kelly, J.G., Andrew, C.J., Ashton, J.H., Boland, M.B., Earls, G., Fusciardi, L., Stanley, T.G., Eds.; Irish Association for Economic Geology: Dublin, Ireland, 2014; pp. 215-238.

55. Harańczyk, C. Ore mineralization of the Lower Zechstein reducing sediments of the Fore-Sudetic Monocline. Arch. Mine. 1972, 30, 13-171. (In Polish)

56. Mayer, W.; Piestrzyński, A. Ore minerals from Lower Zechstein sediments at Rudna mine, Fore-Sudetic monocline, SW Poland. Prace Miner. 1985, 75, 1-72.

57. Sawłowicz, Z. Primary copper sulfides from the Kupferschiefer, Poland. Miner. Depos. 1990, 25, $262-271$. [CrossRef]

58. Piestrzyński, A. Ore mineralization. In Monography of KGHM Polska Miedź SA, 2nd ed.; Piestrzyński, A., Banaszak, A.M., Zaleska-Kuczmierczyk, M., Eds.; Allexim sp.z o.o.: Wrocław, Poland, 2007; pp. 167-197. (In Polish)

59. Pieczonka, J. Factors Controlling Distribution of Ore Minerals within Copper Deposit, Fore-Sudetic Monocline, SW Poland; Wyd. AGH: Kraków, Poland, 2011; pp. 1-195. (In Polish)

60. Piestrzyński, A.; Salamon, W. Perspectives of silver bearing capacity of the eastern part of copper deposits in the Fore-Sudetic Monocline. Gosp. Sur. Min. 1986, 2, 469-481.

61. Piestrzyński, A.; Tylka, W. Silver amalgams from the Sieroszowice copper mine, Lubin-Sieroszowice district, SW Poland. Min. Pol. 1992, 23, 17-25.

62. Kucha, H.; Sawłowicz, Z. Geochemical and mineralogical characteristic of elements associating copper in the western part of Lubin mine. Zesz. Nauk. AGH Geol. 1980, 3, 53-70. (In Polish)

63. Kijewski, P.; Jarosz, J. Metallic mineralization and forms of occurrence of accompanying elements in the copper ore deposit. In The Associated Metals in the Copper Ore Deposit-State of Research and Prospects for Their Further Use; Kijewski, P., Ed.; Cuprum: Wrocław, Poland, 1987; pp. 21-47. (In Polish)

64. Kucha, H. Geochemistry of the Kupferschiefer, Poland. Geol. Rundsch. 1990, 79, 387-399. [CrossRef] 
65. Banaś, M.; Kijewski, P.; Salamon, W.; Pieczonka, J.; Piestrzyński, A. Associated elements in the copper ore deposit. In Monography of KGHM Polska Miedź SA, 2nd ed.; Piestrzyński, A., Banaszak, A., Zaleska-Kuczmierczyk, M., Eds.; Allexim sp.zo.o.: Wrocław, Poland, 2007; pp. 214-228. (In Polish)

66. Idzikowski, A.; Wojciechowska, J. Balance of accompanying elements during ore processing. Pr. Nauk. ICHNiMPR 1971, 8, 3-64. (In Polish)

67. Salamon, W. Ag and Mo in the Zechstein rocks of the Fore-Sudetic Monocline. Pr. Min. PAN 1979, 65. (In Polish)

68. Rahfeld, A.; Wiehl, N.; Dressler, S.; Möckel, R.; Gutzmer, J. Major and trace element geochemistry of the European Kupferschiefer-An evaluation of analytical techniques. Geochemistry 2018, 18, 132-141. [CrossRef]

69. Wood, M.D.; Beresford, N.A.; Copplestone, D. Limit of detection values in data analysis: Do they matter? Radioprotection 2011, 46, S85-S90. [CrossRef]

70. McDonough, W.F.; Sun, S.S. The composition of the Earth. Chem. Geol. 1995, 120, 223-253. [CrossRef]

71. Frenzel, M.; Hirsch, T.; Gutzmer, J. Gallium, germanium, indium, and other trace and minor elements in sphalerite as a function of deposit type-A meta-analysis. Ore Geol. Rev. 2016, 76, 52-78. [CrossRef]

72. Belissont, R.; Boiron, M.C.; Luais, B.; Cathelineau, M. LA-ICP-MS analyses of minor and trace elements and bulk Ge isotopes in zoned Ge-rich sphalerites from the Noailhac-Saint-Salvy deposit (France): Insights into incorporation mechanisms and ore deposition processes. Geochim. Cosmochim. Acta 2014, 126, 518-540. [CrossRef]

73. Johan, Z. Indium and germanium in the structure of sphalerite: An example of coupled substitution with copper. Mineral. Petrol. 1988, 39, 211-229. [CrossRef]

74. Sahlstöm, F.; Arribas, A.; Dirks, P.; Corral, I.; Chang, Z. Mineralogical distribution of germanium, gallium and indium at the Mt Carlton high-sulfidation epithermal deposit, NE Australia, and Comparison with similar deposits worldwide. Minerals 2017, 7, 213. [CrossRef]

75. Cook, N.J.; Ciobanu, C.L.; Pring, A.; Skinner, W.; Shimizu, M.; Danyushevsky, L.; Saint-Eidukat, B.; Melcher, F. Trace and minor elements in sphalerite: A LA-ICPMS study. Geochim. Cosmochim. Acta 2009, 73, 4761-4791. [CrossRef]

76. Schwarz-Schampera, U.; Herzig, P.M. Indium: Geology, Mineralogy, and Economics; Springer: Heidelberg, Germany, 2002.

77. Sawłowicz, Z. REE and their relevance to the development of the Kupferschiefer copper deposit in Poland. Ore Geol. Rev. 2013, 55, 176-186. [CrossRef]

78. Oszczepalski, S.; Chmielewski, A.; Mikulski, S.Z. Controls on the distribution of rare earth elements in the Kupferschiefer series of SW Poland. Geol. Q. 2016, 60, 811-826. [CrossRef]

79. McLennan, S.M. Rare earth elements in sedimentary rocks: Influence of provenance and sedimentary processes. Rev. Miner. 1989, 21, 169-200.

80. Pieczonka, J.; Piestrzyński, A.; Mucha, J.; Głuszek, A.; Kotarba, M.; Więcław, D. The red-bed-type precious metal deposit in the Sieroszowice-Polkowice copper mining district, SW Poland. Ann. Soc. Geol. Pol. 2008, 78, 151-280.

81. Piestrzyński, A.; Pieczonka, J.; Speczik, S.; Oszczepalski, S.; Banaszak, A. Noble metals from the Kupferschiefer-type deposits, Lubin-Sieroszowice, SW Poland. In Mineral Deposits: Resources and Exploration-Where do They Meet; Papunen, H., Ed.; Balkema: Rotterdam, The Netherlands, 1997; pp. 563-566.

82. Oszczepalski, S.; Rydzewski, A. Gold, platinum and palladium in the Lubin-Sieroszowice deposit based on data from boreholes. PTMiner. Pr. Spec. 1998, 10, 51-70. (In Polish)

83. Pieczonka, J.; Piestrzyński, A.; Głuszek, A.; Michalik, A. Occurrence of gold, platinum and palladium in the Polkowice-Sieroszowice deposit area. PTMiner. Pr. Spec. 2011, 10, 71-86. (In Polish)

84. Rapacz, A. Recovery of accompanying metals from KGHM concentrates. PTMiner. Pr. Spec. 1998, 10, 221-240. (In Polish)

85. Blaschke, W.; Witkowska-Kita, B.; Biel, K. Analysis of the possibility of obtaining critical minerals. Annu. Set Environ. Prot. 2015, 17, 792-813. (In Polish)

86. Skirrow, R.G.; Huston, D.L.; Mernagh, T.P.; Thorne, J.P.; Dulfer, H.; Senior, A.B. Critical Commodities for a High-Tech World: Australia's Potential to Supply Global Demand; Geoscience Australia: Canberra, Australia, 2013; pp. 1-126. 
87. Huston, D.L. New age metals: The geology and genesis of ores required for a changing economy and a carbon-constrained world-preface to a thematic issue on critical commodities. Miner. Depos. 2014, 49, 885-887. [CrossRef]

88. Sykes, J.P.; Wright, J.P.; Trench, A.; Miller, P. An assessment of the potential for transformational market growth amongst the critical metals. Appl. Earth Sci. 2016, 125, 21-56. [CrossRef]

89. Jowitt, S.M.; Mudd, G.M.; Werner, T.T.; Weng, Z.; Barkoff, D.W.; McCaffrey, D. The critical metals: An overview and opportunities and concerns for the future. SEG Spec. Publ. 2018, 21, 25-38.

90. Nassar, N.T.; Graedel, T.E.; Harper, E.M. By-product metals are technologically essential but have problematic supply. Sci. Adv. 2015, 1, 1-10. [CrossRef]

91. Mudd, G.M.; Jowitt, S.M.; Werner, T.T. The world's by-product and critical metal resources. Pt. I: Uncertainties, current reporting practices, implications and grounds for optimism. Ore Geol. Rev. 2017, 86, 924-938. [CrossRef]

92. Werner, T.T.; Mudd, G.M.; Jowitt, S.M. The world's by-product and critical metal resources. Pt. II. A method for quantifying the resources of rarely reported metals. Ore Geol. Rev. 2017, 80, 658-675. [CrossRef]

93. Barbalance, K. Periodic Table of Elements. Available online: https://environmentalchemistry.com/yogi/ periodic (accessed on 19 July 2019).

94. Kijewski, P.; Wirth, H. Rhenium-Occurrence in copper ore deposit, the production and its perspectives. Zesz. Nauk. IGSMiE PAN 2011, 81, 103-115. (In Polish)

95. Serkies, J. The epitome of geochemistry of the Fore-Sudetic copper deposit. Pr. Nauk. ICHNiMPR 1972, 12. (In Polish)

96. Salamon, W. The relationship between cobalt and nickel in copper deposits on the Fore-Sudetic Monocline. PTMiner. Pr. Spec. 1993, 3, 89-96. (In Polish)

97. Piestrzyński, A.; Mucha, J.; Bachowski, C.; Głuszek, C.; Michalik, A.; Szarowski, W.; Serafin, W.; Tomanik, R.; Zimocha, R. Cobalt in the copper ore deposit on the Fore-Sudetic Monocline, SW Poland. PTMiner. Pr. Spec. 1998, 10, 119-139. (In Polish)

98. Pazik, P.M.; Chmielewski, T.; Glass, H.J.; Kowalczuk, P.B. World production and possible recovery of cobalt from the Kupferschiefer stratiform copper ore. EDP Sci. 2016, 8, 01063. [CrossRef]

99. Kucha, H.; Mayer, W.; Piestrzyński, A. Vanadium in the copper ore deposits on the Fore-Sudetic Monocline (Poland). Min. Pol. 1983, 14, 35-43.

100. Kucha, H.; Przybyłowicz, W. Noble metals in organic matter and clay-organic matrices, Kupferschiefer, Poland. Econ. Geol. 1999, 94, 1137-1162. [CrossRef]

101. Speczik, S. Kupferschiefer mineralization in the light of organic geochemistry and coal petrology studies. Geol. Q. 1994, 38, 639-650.

102. Wodzicki, A.; Piestrzyński, A. An ore genetic model for the Lubin-Sieroszowice mining district, Poland. Miner. Depos. 1994, 29, 30-43. [CrossRef] 